\title{
Composers as parents: Selected twentieth-century piano works written by fathers for their children
}

Onpavee Nitisingkarin

Follow this and additional works at: https://researchrepository.wvu.edu/etd

\section{Recommended Citation}

Nitisingkarin, Onpavee, "Composers as parents: Selected twentieth-century piano works written by fathers for their children" (2015). Graduate Theses, Dissertations, and Problem Reports. 6321.

https://researchrepository.wvu.edu/etd/6321

This Dissertation is protected by copyright and/or related rights. It has been brought to you by the The Research Repository @ WVU with permission from the rights-holder(s). You are free to use this Dissertation in any way that is permitted by the copyright and related rights legislation that applies to your use. For other uses you must obtain permission from the rights-holder(s) directly, unless additional rights are indicated by a Creative Commons license in the record and/ or on the work itself. This Dissertation has been accepted for inclusion in WVU Graduate Theses, Dissertations, and Problem Reports collection by an authorized administrator of The Research Repository @ WVU.

For more information, please contact researchrepository@mail.wvu.edu. 


\title{
COMPOSERS AS PARENTS: SELECTED TWENTIETH-CENTURY PIANO WORKS WRITTEN BY FATHERS FOR THEIR CHILDREN
}

\author{
Onpavee Nitisingkarin
}

\author{
A Doctoral Research Project submitted to the \\ College of Creative Arts \\ at \\ West Virginia University \\ in partial fulfillment of the requirements for the degree of \\ Doctor of Musical Arts \\ in \\ Piano Performance
}

Peter Amstutz, D.M.A., Chair

William Haller, D.M.A.

Keith Jackson, D.M.A.

Penprapa Klinkhachorn, Ph.D.

Lucy Mauro, D.M.A., Research advisor

\author{
School of Music \\ Morgantown, West Virginia \\ 2015
}

Keywords: 1) piano music for children 2.) Dallapiccola Annalibera 3.) Stravinsky Valse

4.) Shostakovich exercise 5.) Montsalvatge Sonatine 6.) Dollo Joio children 7.) fathers

(C) 2015 Onpavee Nitisingkarin 


\section{ACKNOWLEDGEMENTS}

I would like to express my gratitude to my dissertation advisor Dr. Lucy Mauro, who devoted her time to work with me and assist me throughout these years. I also thank my piano teacher and mentor, Dr. Peter Amstutz, for his time helping to edit the paper. Additionally, thanks go to my other committee members for their helpful thoughts and suggestions. Lastly, I would like especially to thank my parents and sister, whose financial and emotional support helped me through my DMA degree.

Onpavee Nitisingkarin

May 2015 


\section{ABSTRACT \\ Composers as Parents: Selected Twentieth-Century Piano Works Written by Fathers for Their Children}

\section{Onpavee Nitisingkarin}

This research paper, "Composers as Parents: Selected Twentieth-Century Piano Works Written Fathers for Their Children," focuses on compositions by Igor Stravinsky, Luigi Dallapicola, Dmitri Shostakovich, Xavier Montsalvatge, and Norman Dello Joio. This study includes solo and four-hand piano works and examines pedagogical approaches, stylistic elements, and the historical background of each work. The pieces examined are each dedicated to the composer's child and served as teaching materials, domestic entertainment, or gifts. The music discussed represents a broad range of difficulty from late elementary to early advanced levels. A brief biography of each composer and a discussion of significant elements in each work provide information for teachers, students, and performers. 


\section{TABLE OF CONTENTS}

\section{CHAPTER}

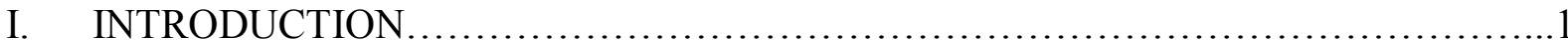

Purpose of the Study

Need for the Study

Limitations of the Study

II. REVIEW OF RELATED LITERATURE........................................

III. DISCUSSION OF LEVELS IN PIANO REPERTOIRE (LATE ELEMENTARY .......11 TO ADVANCED)

IV. IGOR STRAVINSKY: Valse pour les enfants...................................... 17

V. LUIGI DALLAPICCOLA: Quaderno Musicale di Annalibera ...........................26

VI. DMITRI SHOSTAKOVICH: A Child's Exercise Book, Op. 69........................68

VII. XAVIER MONTSALVATGE: Sonatine for Yvette.................................93

VIII. NORMAN DELLO JOIO: Family Album for one piano, four hands.....................114

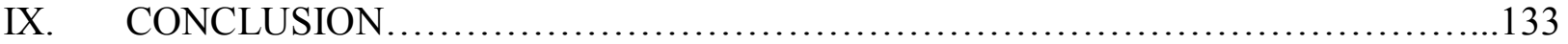

BIBLIOGRAPHY .......................................................... 137 


\section{CHAPTER I \\ INTRODUCTION}

\section{$\underline{\text { Purpose of the Study }}$}

The purpose of this research study is to provide information on and expand the twentiethcentury musical palette of piano repertoire through lesser-known pieces written by selected composers for their children. Each of the works studied served different purposes for the selected composers, from pedagogical instruction, presents, or family entertainment. The discussion and survey included here intend to give teachers as well as students additional options in repertoire selection. Moreover, this repertoire also serves as effective works for students' first engagements with contemporary music and as a substitution for some standard works that feature similar twentieth-century compositional techniques and ideas.

\section{Need for the Study}

Many composers have written pieces or collections of piano and keyboard works for or about their children. Such literature has been written for many different purposes including teaching, family recreation, reminiscences of childhood, and more. Examples of famous works include J.S. Bach's Clavier-Büchlein vor Wilhelm Friedemann Bach and Schumann's Album for the Young. Both of these works are the craft of fathers who wrote for their own children (J.S. Bach wrote for his son and Schumann wrote for his three daughters) as didactic materials. The most well-known piano or keyboard music written for children is dated before 1900. Unfortunately, most repertoire by established composers that has been written for children since 1900 is barely known. Bartok's Mikrokosmos is one of the very few exceptions, as it is one of the 
few post-1900 piano works written for a child with which piano teachers and students are familiar. Nevertheless, it is important for piano teachers and students to learn about these lesserknown, but still valuable piano pieces written during this era. Therefore, it is helpful for both piano teachers and students to explore and expand their repertoire options to develop pianistic skills and gain a better understanding of styles, pedagogical concerns, and historical background.

\section{$\underline{\text { Scope and Limitation }}$}

Pieces selected in this research are Stravinsky's Valse pour les enfants; Dallapiccola's Quaderno Musicale di Annalibera; Shostakovich's A Child's Exercise Book, op. 69; Montsalvatge's Sonatine for Yvette; and Dello Joio's Family Album. This selection includes solo piano pieces and collections as well as some music for piano duet. Each piece of music or collection is presented in its own chapter in chronological order. An initial discussion regarding level of difficulty in piano literature is presented as an independent chapter. The outline of discussion in each chapter features: 1) the composer's brief biography, 2) the composer's musical style, 3 ) the historical background and purpose, 4) the level of difficulty, 5) a survey of the piece or set of pieces, and 6) pedagogical aspects. 


\section{CHAPTER II}

\section{REVIEW OF RELATED LITERATURE}

Twentieth-century piano music is often overlooked in piano repertoire and pedagogical studies, especially for elementary and intermediate level students. For this reason, documents that deal directly with some of the works selected in this research, such as those of Norman Dello Joio, do not exist. The sources reviewed in this study include books, dissertations, and articles, all of which are limited to sources written in English and those that are available through West Virginia University Libraries and its facilities.

Susan Hall Foster wrote her M.M. thesis, "The Solo Piano Works of Igor Stravinsky,"1 in 1972. This thesis provides a discussion regarding all of Igor Stravinsky's piano music in terms of history, theory, and pedagogy The author organizes the research into five main chapters: 1) A Survey of the Solo Piano Works of Stravinsky in Relation to Other Contemporaneous Works, 2) Didactic Works, 3) Works in Popular Idiom, 4) Concert Pieces, and 5) Stravinsky’s Writing for the Piano. The author presents Valse pour les enfants in the second chapter, "Didactic Works." In this chapter, the author provides an analysis regarding structure, tonality, melody, tempi, and harmony of the piece. Moreover, Forster writes a brief note regarding pedagogical concerns as well as a few words from the composer himself at the end of the discussion.

In Stravinsky's Piano: Genesis of a Musical Language, ${ }^{2}$ Graham Griffiths explores Stravinsky's compositional processes. ${ }^{3}$ Griffiths believes that Stravinsky's relationship with the

\footnotetext{
${ }^{1}$ Susan H. Forster, “The Solo Piano Works of Igor Stravinsky.” (M. M. thesis, Indiana University, 1972).

${ }^{2}$ Graham Griffiths, Stravinsky's Piano: Genesis of a Musical Language. (Cambridge: University Press, 2013).
} 
piano forms the basis for his entire musical output. Valse pour les enfants is mentioned briefly in the fourth chapter, "Departures and Homecomings." However, a specific, detailed discussion of this particular piece is not included.

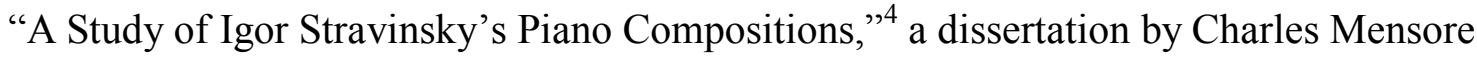
Joseph, is divided into two parts: 1) History, and 2) Analysis. The author presents Valse pour les enfants in the seventh chapter, "Miscellaneous Works with Piano," briefly examining information about this piece regarding its style and compositional background.

There are three main sections in Marlene Thal's PhD dissertation "The Piano Music of Igor Stravinsky." In the first part, "A General Survey of Works for Piano," the author presents Stravinsky's concept of "composing at the piano," something which he inherited from RimskyKorsakov. The next part of the dissertation concerns solo-piano works. Thal divides this discussion into two main categories: 1) Original Works for Solo Piano, and 2) Solo Piano Transcriptions of Instrumental Works. For each work, the author notes the historical background as well as an overall survey. Thal begins the discussion of Valse pour les enfants with its historical background, followed by a presentation of stylistic elements of the work. In addition, she also provides a brief note regarding Valse pour les enfants in the penultimate chapter, "The Works for Piano in the Context of the Composer's Four Style Periods." Those periods include:

\footnotetext{
${ }^{3}$ Ibid, 8 .

${ }^{4}$ Charles M. Joseph, “A study of Igor Stravinsky's Piano Compositions.” (Ph.D. diss., University of Cincinnati, 1974.)

${ }^{5}$ Marlene Thal, “The Piano Music of Igor Stravinsky.” (Ph.D. diss., University of Washington, Seattle, 1978).
} 
1) the student years, 2) the experimental years, 3) the neo-classical period, and 4) the serial period. ${ }^{6}$

Robert Craft wrote Stravinsky: Selected Correspondence, Volume 1 in 1982. The book contains letters written throughout different periods of his life. The author has entitled each chapter with the name of the person with whom Stravinsky was corresponding. The book is comprised of nine main chapters which are entitled Catherine and God, Maurice Delage, V.V. Derzhanovsky, Jean Cocteau, Ernest Ansermet, Nadia Boulange, Lincoln Kirsten, W. H. Auden; and the author himself. Moreover, Craft also includes insightful and interesting documents divided into 12 appendices. Those include such pieces as Stravinsky's family documents, Stravinsky's French citizenship, and several documents containing information about some of his manuscripts and compositions. The author features insightful information regarding each work's publication date and purpose in the "Appendix G: Easy Pieces."

The Music of Luigi Dallapiccola, written by Raymond Fearn and published in 2003, gives detailed information on the composer's biography as well as his compositional output. The author has separated this book into six main each chapters, which correspond to each period in Dallapiccola's life in chronological order. Each chapter also contains a survey and a moderate analysis of works during each time frame. The discussion of Quaderno musicale di Annalibera is featured in the fourth chapter of the book. The author includes information concerning the historical background and purpose of the piece as well as a survey of structural, motivic, and stylistic elements in each movement.

\footnotetext{
${ }^{6}$ Ibid., 109.
} 
A music-theory Master's thesis entitled "Tonal references in Luigi Dallapiccola's Quaderno Musicale Di Annalibera” by Rachel Elice Mann provides a discussion regarding tonal references in Quaderno Musicale Di Annalibera with an emphasise on two selected movements: I. "Simbolo" and VII. "Andantino Amoroso e Contrapunctus Tertius-Resolutio." The author breaks down the tonal references into three possibilities which are through the "triadic seventh chords," chordal transformations, and "local tonic-dominant relationship." The thesis is comprised of four chapters which include the introduction, analysis of movement I, analysis of movement VII, and conclusion. A brief overview of the entire work and biography of the composer is presented in chapter I. Moreover, the author also includes a literature review of similar works in the same time frame and genre in the first chapter.

A doctoral dissertation, "Salute to Bach: Modern Treatments of Bach-Inspired Elements in Luigi Dallapiccola's Quaderno Musicale di Annalibera and Heitor Villa-Lobos' Bachianas Brasileiras No. $4^{\prime \prime}$ by Shu-Ting Yang mentions Bach inspirations in both Luigi Dallapiccola's Quaderno Musicale di Annalibera and Heitor Villa-Lobos's Bachianas Brasileiras No.4. The Bach inspiration includes elements such as the B-A-C-H theme, which is utilized throughout both of these works, as well as Baroque compositional techniques. The paper is divided into seven main chapters. The author provides a discussion regarding Quaderno Musicale di Annalibera in chapter two and chapter three. Chapter two features a discussion regarding Luigi Dallapiccola as well as his musical style. Chapter three provides homage to Bach and contains a discussion pertaining to the background of the work, modern treatments of Baroque elements in

\footnotetext{
${ }^{7}$ Rachel Elice Mann, “Tonal references in Luigi Dallapiccola's Quarderno Musicale Di Annalibera”( MM thesis, Texas Tech University, 2002.)

${ }^{8}$ Shu- Ting Yang, "Salute to Bach: Modern Treatments of Bach-Inspired Elements in Luigi Dallapiccola's Quaderno Musicale di Annalibera and Heitor Villa-Lobos' Bachianas Brasileiras No. 4 " (DMA diss., The University of Cincinnati, 2007)
} 
the piece, and an analysis of each movement. Additionally, the author provides a comparison between Variazioni per orchestra (an orchestrated version of Quaderno Musicale di Annalibera) and Heitor Villa- Lobos's Bachianas Brasileiras No.4 in chapter six.

A PhD dissertation, “The Piano Works of Luigi Dallapiccola (1904-1975): An Analysis Performance," was written by Sue Burnett Petito in 1989. Petito presents "Life and Times of Dallapiccola" and "The Musical Scene Dallapiccola Encountered With" in chapter two. Chapter three focuses on the music of Dallapiccola over three periods (early, middle, and late). Quaderno Musicale di Annalibera is presented in chapter nine. Petito begins the chapter with a historical background of this work as well as a general observation in comparison to its predecessor, a work that J.S. Bach composed. The discussions included are: "General Form and Structure," "General Performance Instruction," and "Dodecaphony and Large-Scale Continuity" as well as a detailed analysis and performance considerations for each movement in the set.

Micheal Ardov compiled interviews with Shostakovich's children (Maxim and Galina) in Memories of Shostakovich. ${ }^{10}$ This book is a record of Shostakovich's life through accounts by both of his children. In chapter fourteen, Galina mentions the historical background of "special little compositions for children" that her father composed for her.

Jane Magrath writes about Children's Notebook, Op. 69 in chapter sixteen, “The Piano Music of Dmitri Shostakovich: Creative Genius versus the Suppression of Artistic Expression,”

\footnotetext{
${ }^{9}$ Sue B. Petito “The Piano Works of Luigi Dallapiccola (1904-1975): An Analysis for Performance.” (PhD diss., New York University, 1989.)

${ }^{10}$ Micheal Ardov. Memories of Shostakovich: Interviews with the Composer's Children and Friends, (Great Britain: Mackays of Chatham Ltd., 2004)
} 
in The Pianist's Craft: Mastering the Works of Great Composers. ${ }^{11}$ Magrath briefly mentions the Children's Notebook, op. 69 examining its purpose and difficulty level.

Ronald Stevenson writes a chapter about Shostakovich's piano music in Shostakovich: the Man and his Music. ${ }^{12}$ Stevenson describes Shostakovich's piano works in comparison to his other works, including symphonies and quartets. According to Stevenson, Shostakovich's symphonies are considered his "private" type of music, whereas the quartets are considered "public." Stevenson considers the piano music to fall somewhere between those two genres. The author also explains that Shostakovich was capable of using the piano to express his tragic and sarcastic ideas. Later on in that chapter, the author also discusses Shostakovich's musical and piano education. Finally, the author discusses each of Shostakovich's piano works chronologically. The author examines the Children's Notebook, Op. 69 by providing information about the history of this set and a general discussion about Soviet composers of children's music. However, the author does not provide any discussion of analysis, performance practice, or pedagogical issues.

Martha L. Violett wrote a DMA dissertation, "The Solo Piano Music of Xavier Montsalvatge." ${ }^{\prime 13}$ A presentation of Sonatine pour Yvette is featured in chapter three. Violett first presents a historical background of Sonatine pour Yvette followed by an analysis of each

\footnotetext{
${ }^{11}$ Jane Magrath, The Piano Music of Dmitri Shostakovich: Creative Genius Versus the Suppression of Artistic Expression In The Pianist's Craft: Mastering the Works of Great Composer, (Lanham, MD: Scarecrow Press, 2012).

${ }^{12}$ Ronald Stevenson. "The Piano Music" In Shostakovich, the Man and his Music. (Boston; London: M. Boyars, 1982).

${ }^{13}$ Martha L. Violett. "The Solo Piano Music of Xavier Montsalvatge." (PhD diss., University of Iowa, 1990).
} 
movement emphasizing the thematic relationships, "chromaticism and chromatic movements of harmonies" utilized in the piece, and formal organization.

Frances Dillon's article "Family Album. Piano Duets by Norman Dello Joio" 14 in Notes reviews this work in 1963. Dillon categorizes the Family Album in the upper elementary and intermediate levels. The author has a favorable impression of this work, as he states in this critique, "This reviewer thinks the teacher will be fortunate to have the opportunity of using the album, for it ranks highly among the too-few original four-hand duets."15 Furthermore, the author provides a general survey and discusses pedagogical issues. He also suggests to the publisher improvements for the next re-print edition.

Andrea Jeanne Steffan’s D.M.A. dissertation “Selected Piano Works by Norman Dello Joio" is from 2001. ${ }^{16}$ Two didactic works composed for Dello Joio’s own children (Victoria, Justin and Norman) are studied in this research: Suite for the Young (1964), and Lyric Pieces for the Young (1971). These two works are presented in chapter two, "Works for Piano." Steffan provides a general survey of both works regarding difficulty level, significant elements in some movements, stylistic aspects of Dello Joio’s music, and some pedagogical concerns.

In 1970 Maurice Hinson wrote an article, The Solo Piano Music of Norman Dello Joio, ${ }^{17}$ in American Music Teacher. Hinson's two-page article comprises a brief biography, musical style, and a survey of Dello Joio's solo piano works. Hinson categorizes those works examined

\footnotetext{
${ }^{14}$ Frances Dillon. "Family Album. Piano Duet by Norman Dello Joio” Notes 21, no. 1/2 (Winter, 1963 -Spring): 248.

${ }^{15}$ Ibid, 248.

${ }^{16}$ Andrea J Steffan. "Selected Piano Works by Norman Dello Joio." (PhD diss., University of Cincinnati, 2001).

${ }^{17}$ Maurice Hinson. “The Solo Piano Works of Norman Dello Joio.” American Music Teacher 19, no. 1 (01/01; JanFeb, 1970): 34-48.
} 
in the review into two main groups: 1) larger works, such as his three sonatas, and 2) smaller works, such as character pieces, suites, and others. Dello Joio's Suite for the Young, Family Album, and Five Images are presented in the penultimate paragraph. The author provides a short description of each set regarding the year of composition, its style, and significant features of the works.

Sister Elizabeth Adams has a chapter about Dello Joio’s piano works in her D.M.A. dissertation entitled "The Treatment of the Piano Suite in the Twentieth Century as Exemplified by Schoenberg, Dello Joio, Donovan, and Apostel." 18 This research focuses on piano suites of Dello Joio as well as these by the other selected composers. The author briefly mentions Dello Joio's biography, musical style, and piano works. Adams presents Suite for the Young, Family Album, and Five Images under the topic of "Pedagogical Compositions." However, the presentation only briefly mentions details such as date of composition, objectives of the works, difficulty level, and number of movements per work.

\footnotetext{
${ }^{18}$ Elizabeth Adams. "The Treatment of the Piano Suite in the Twentieth Century as Exemplified by Schoenberg, Dello Joio, Donovan, and Apostel." (DMA diss, University of Cincinnati, 1974)
} 


\section{CHAPTER THREE}

\section{A Discussion of Levels in Piano Repertoire}

In order to help students and teachers gain a better understanding of the levels mentioned in this research paper, characteristics in each level from late elementary to early advanced are discussed below. The characteristics provided here resulted from a survey of levels found in multiple sources including J. Bastien's How to Teach Piano Successfully, J. Magrath's The Pianist's Guide to Standard Teaching and Performance Literature, the Associated Board of the Royal School of Music, UK, (ABRSM) ${ }^{19}$, and the Music Development Program in the USA $(\mathrm{MDP})^{20}$.

The various levels of piano literature can be generally divided into three main categories: elementary, intermediate, and advanced. The elementary and intermediate categories may be further subdivided into early, middle, and late, while the advanced is broken down into early advanced and advanced. The pieces discussed in this paper range from late elementary through early advanced. The information below describes the general characteristic of each level: late elementary, early intermediate, middle intermediate, late intermediate, and early advanced.

\section{$\underline{\text { Late Elementary }}$}

- $\quad$ Notes reading within the staff with one or two additional ledger lines

- $\quad$ Basic musical symbols such as repeat, D.C. al fine, tie, and slur

- White-key hand positions (i.e., C, G, D, F) with basic hand shifting

- $\quad$ Finger extension from five finger position to sixth, seventh, and one octave

\footnotetext{
${ }^{19}$ http://www.abrsm.org/en/regions/usa/united-states/home/ (accessed February 28, 2014)

${ }^{20}$ http://www.musicdevelopmentprogram.org/ (accessed February 28, 2014)
} 
- $\quad$ Basic finger crossing based on major and minor scale patterns

- $\quad$ Major and minor keys up to two sharps and two flats with occasional accidentals, along with simple blues scale patterns and whole-tone scales

- $\quad$ Basic articulations such as staccato, legato, and two-note slur

- $\quad$ Simple balance of melody and accompaniment between the hands

- $\quad$ Basic rhythm up to eighth notes and triplets

- $\quad$ Basic simple and compound meters

- $\quad$ Familiarity with basic Italian musical terms such as Allegro, Adagio, and Moderato.

- $\quad$ Simple musical forms such as short Binary and Ternary

- $\quad$ Simple melody and accompaniments, including Alberti bass, and triads and their inversions, played harmonically and melodically

- Basic dynamics including forte, piano, crescendo, and diminuendo

- $\quad$ Basic use of the damper pedal

- $\quad$ Simple interpretation and use of creative story, sounds and movements, which relate to the music

\section{$\underline{\text { Early Intermediate }}$}

- $\quad$ Note reading within the staff with three or four additional ledger lines, and use of 8va

- $\quad$ Reading intervals from unison to a tenth (i.e., C and E)

- $\quad$ Symbols such as sforzando, accent, and portato are introduced

- $\quad$ Extended hand position (i.e., C, G, D, A, F). Single-hand displacement is expected with some two-hand displacement.

- $\quad$ Simple hand crossing with patterns

- $\quad$ Keys include major and minor up to three sharps and three flats, with occasional accidentals, and chromatic scales

- $\quad$ More nuanced articulation and voicing

- $\quad$ More advanced use of patterns, finger independence, and some basic forearm rotation 
- $\quad$ Rhythm extended to the use of sixteenth notes

- $\quad$ More advanced use of dynamics and balance between hands

- $\quad$ More advanced damper pedal usage (rhythmic and syncopated)

- $\quad$ Exploration of more complex emotional involvement

\section{Middle Intermediate}

- $\quad$ Reading almost all conventional on-staff notation

- $\quad$ Musical terminology becomes more advanced

- $\quad$ Reading and playing pitches within a three-octave span for both hands

- $\quad$ More advanced hand displacement (including both hands shifting)

- More advanced and rapid hand crossing patterns as well as basic finger substitution

- $\quad$ Keys include major and minor keys up to four sharps and flats

- $\quad$ More variety in the tonality in repertoire including easy jazz harmonies as well as exotic harmonies such as whole tone scales and pentatonic scales

- $\quad$ More nuance and variety in articulations and difference of tone production according to suitable musical styles for each specific period

- A combination of different articulations for each hand

- $\quad$ More advanced voicing technique

- $\quad$ More variety of tempi and the introduction of tempo rubato and accelerando

- $\quad$ Extension of musical forms such as binary, ternary, variations, sonatina, short dances, and short Romantic character pieces

- Introduction of non-traditional and contemporary harmony as well as basic counterpoint

- $\quad$ More nuanced range of dynamics and contrast between dynamics

\section{$\underline{\text { Late Intermediate }}$}

- $\quad$ Notes and rhythmic readings are mastered by students themselves with little help from teachers 
- Greater presence of syncopated rhythms. Polyrhythms and cross rhythms, such as three against two are introduced

- $\quad$ Reading and playing ornamentations such as acciaccaturas, appoggiaturas, turns, and trills

- $\quad$ Familiarity with basic cross-over notation in navigating a musical line that is passed from one hand to the other.

- $\quad$ Reading and playing all pitches nearly spanning the entire keyboard

- Hand displacement and crossing including sudden shift in hand position

- $\quad$ Extended fingerings, finger substitution, and basic repeated-note playing technique (i.e, 3-2-1 fingering)

- $\quad$ Major and minor keys up to five sharps and flats with more variety in tonality within a work

- $\quad$ Both parallel and contrary motion scales in three octaves or more and in different rhythmic groupings such as triplets or running sixteenth notes.

- $\quad$ Arpeggios, chords, and their inversions

- $\quad$ Application of whole body support when playing of loud chords and sounds.

- $\quad$ More complicated rhythms with more syncopation, ties between beats and bars, and the combination of simple and compound rhythms

- $\quad$ More velocity in music as well as more complex textures in slow music

- $\quad$ Exploration of more musical forms such as easy sonatas (i.e., Haydn and Mozart), short dances, and short Romantic character pieces (some with descriptive titles)

- More variety in musical texture, includes both homophonic and polyphonic

- $\quad$ More chromatic, extended, and contemporary harmonies

- $\quad$ More variety, and abrupt or gradual changes in dynamics

- Introduction to una corda pedal

- Deeper musical interpretation 


\section{$\underline{\text { Early Advanced }}$}

- Traditional realization of ornaments from different musical periods

- New signs and markings in new music (especially in twentieth to twenty-first century music)

- $\quad$ Hand positions make use of the entire keyboard with abrupt hand shifts to different registers of the piano

- $\quad$ Extended fingerings (more than an octave), finger substitution, basic repeated-note playing technique

- $\quad$ Faster and more complex technical abilities such as scales, large chords, and arpeggios

- $\quad$ All major and minor keys

- $\quad$ Scales and arpeggios in $3^{\text {rds }}, 6^{\text {ths }}$, and octaves, and in various rhythms. Appearance of exotic scales (such as the Gypsy scale) and modes.

- $\quad$ Extended chord usage such as $7^{\text {th }}, 9^{\text {th }}$, and $11^{\text {th }}$

- $\quad$ Bigger interval spans to more than an octave such as ninths and tenths.

- A wide variety of articulation, and a variety of methods of tone production, as controlled by support from different parts of the body and hands

- $\quad$ Variety of articulation in the same hand

- $\quad$ More complexity in rhythm and more syncopation

- Various tempi within one piece of music

- $\quad$ Virtuosic playing

- $\quad$ More complex time signatures, along with the use of polyrhythm, polymeter, metric transformations, changing rhythms, and mixed rhythms

- $\quad$ More ambiguous and chromatic harmony, the resolution of progressions is not always direct, but can be prolonged; more extended and contemporary harmonies

- $\quad$ More variety in dynamics and gradation of sound

- $\quad$ All pedals are used: damper (overlapping pedal, rhythmic pedal, as well as fluttering and half pedal), una corda, and sostenuto 
- $\quad$ More mental as well as physical and emotional involvement in music; more understanding of the drama of music and playing with an appropriate musical interpretation for each specific period and style 


\section{CHAPTER FOUR}

\section{Valse pour les enfants by Igor Stravinsky (1882-1971)}

Igor Stravinsky is considered to be one of the most important figures in twentieth-century music, not only as a composer, but also as a conductor, pianist, author, lecturer, and polemicist. Born in Russia, he relocated many times and to many places throughout his adult life, including Switzerland, France, and finally the United States of America, and his musical style is varied and diverse.

Stravinsky’s early influences in music came from his family. His father was a singer and his mother was a pianist. However, Stravinsky mentioned in the Journal de Genève that his father wished him to stay away from an artist's life, as he knew the obstacles to earning a living as a musician. ${ }^{21}$ In any case, eventually Stravinsky’s father, Fyodor, asked his friend, RimskyKorsakov, to help in his compositional studies. Stravinsky was attracted to the piano by his mother's playing and was even more drawn to her ability to sight read, a talent which he claimed that he also inherited from her. In addition, Stravinsky also showed his inclination toward being a composer from a very young age. While at nursery school, when a military band went parading by, he heard the tune played by the band and tried to find the intervals he heard at the piano. However, during the process of finding those intervals, he discovered other intervals that he liked more. ${ }^{22}$

\footnotetext{
${ }^{21}$ Charles M. Joseph, Stravinsky and the Piano (Ann Arbor, Michigan: UMI Research Press, 1983), 3

${ }^{22}$ Ibid, 4.
} 
Stravinsky's works can be divided into three main compositional periods. These are Russian and pan-diatonic (1902-1919), neo-classical (1920-1950), and serial (1951-1971). ${ }^{23}$ The music during his Russian period includes such ballet compositions as The Firebird (1910), Petrushka (1911), and The Rite of Spring (1913). Later, around 1920, Stravinsky wrote more music that harkens back to the Classical style. His music during this time has less of a connection with ballet and theatre. Some such compositions are Symphony of Wind Instruments (1920), Symphony of Psalms (1930), and Symphony in Three Movements (1945). He also wrote several operas, one prominent example being The Rake's Progress (1951) which featured his neoclassical style of writing. The twelve-tone techniques developed by Arnold Schoenberg also influenced Stravinsky in his music. From 1951, Stravinsky began using twelve-tone techniques in his compositions such as In Memoriam Dylan Thomas (1954), Agon (1954-57), and Canticum Sacrum (1955).

The piano music of Stravinsky is considered small in amount when compared with the music he wrote for other instruments, even though the piano was his very first instrument. Nevertheless, most of his earliest compositions were for piano. His piano music in the first period includes pieces such as Scherzo (1902), Sonata in f-sharp (1902-3), and Four Etudes, Op. 7 (1908). These pieces illustrate the Romantic tradition that influenced Stravinsky's writing. The neo-classical piano pieces of Stravinsky include works such as Three-Movement Sonata (1924) and Serenade en la (1925). During his neo-classical period, Stravinsky transcribed his ballet compositions into works for piano, as can be seen in three pieces from Petrushka (1921). During this time, Stravinsky also wrote shorter works for piano. Examples of such pieces include Piano Rag Music (1919), Tango (1940), Circus Polka for a Young Elephant (1942), Les cinq doigts 
(1921), and Valse pour les enfants (1917/1922). ${ }^{24}$ In addition, Stravinsky wrote a few works for piano and orchestra: the Concerto for Piano and Wind Instruments (1923-4, revised 1950), Capriccio for Piano and Orchestra (1928-9, revised 1949), Concerto for Two Solo Pianos (1935), and Movements for Piano and Orchestra (1958-59).

Among Stravinsky's piano works are those for didactic purposes, especially those written during his Russian period (1902-1919), while he was residing in Switzerland (1914- 1920). Stravinsky married twice and had four children with his first wife, Catherine Nossenko (18811939). They are Fyodor (Theodore) Stravinsky, Ludmila (Mika) Stravinsky, Sviatoslav Soulima Stravinsky, and Maria Milena Stravinsky. However, he did not have any children with his second wife, Vera de Bossett (1888- 1982), whom he married in 1940. His musical output during this period contains several works written for or about his children. The piano compositions during this period make up a good portion of his works from this time. Additionally, some of the pedagogical pieces were written in France, including Stravinsky's arrangement of a cavatina from Glinka's Russlan and Ludmilla in 1916. This was intended as a gift for his youngest son, Soulima Stravinsky, for his first piano instruction. ${ }^{25}$ Unfortunately, according to Joseph, this arrangement is now probably lost. ${ }^{26}$ Valse des fleurs, written September 30, 1914, is also one of the earlier piano works by Stravinsky. The others include Three Little Songs ('Recollections of My Childhood'), Pribaoutki (1914), and Three Easy Pieces (1914/15, piano duet) for Diaghilev and probably for Soulima (solo version), ${ }^{27}$ The Cat's Cradle Songs (1915/16), Renard (1916),

\footnotetext{
${ }^{24}$ Stewart Gordon, A History of Keyboard Literature: Music for the Piano and Its Forerunners (Belmont, CA: Schirmer, 1996), 439.

${ }^{25}$ Charles M. Joseph, Stravinsky and the Piano (Ann Arbor, Michigan: UMI Research Press, 1983), 58.

${ }^{26}$ Ibid

${ }^{27}$ Ibid, 62 .
} 
Three Tales for Children (1916), and Berceuse (1917) for his daughter, Mika, Five Easy Pieces (1917) inspired by his two eldest children, Theodore and Mika, Les cinq doigts (1921), and Valse pour les enfants (1922), and Concerto for Two Solo Pianos (1935). The concerto, a later, advanced-level piece, was written for collaboration with his son, Soulima. The work selected for focus here is a solo-piano piece, which the composer wrote for his own family members, Valse pour les enfants (1916-1917/1922).

Valse pour les enfants was composed from December 1916 through January 1917. It was published five years later in 1922 in a Sunday issue of the Parisian daily Le Figaro, with handwritten "pour les petits lecteurs du Figaro, mai 1922" in Le Figaro Supplément Littéraire, May $21,1922 .{ }^{28}$ Craft mentions that the reason that Stravinsky did not commercially publish this work until many years later could have been because Le Figaro might have asked him to compose a new piece for which he would have been paid. C.M. Joseph said, "It is quite likely that this work was originally intended as a pedagogical gift for his children and his family, not the Figaro." ${ }^{29}$ Moreover, Joseph mentioned in Stravinsky and the Piano that the composer also faced financial difficulty around $1922 .{ }^{30}$ There was a preface that is likely from the editor saying “Valse pour les enfants, improvise au Figaro par Igor Stravinsky...une valse pour les petits lectuers du Figaro." ${ }^{31}$ The newspaper printed that Stravinsky "had 'improvised' the work on the premises. ${ }^{32}$ (See Example 6-1) However, the composer wrote a correction with his own handwriting about the piece in the facsimile of two copies of the newspaper. The first copy says

\footnotetext{
${ }^{28}$ Robert Craft, Stravinsky: Selected Correspondence Volume 1 (New York: Alfred A. Knopf, 1982), 413.

${ }^{29}$ Charles M. Joseph, Stravinsky and the Piano (Ann Arbor, Michigan: UMI Research Press, 1983), 66.

${ }^{30}$ Ibid

${ }^{31}$ Ibid

${ }^{32}$ Ibid, 414.
} 
“Mensonge, ce n'est pas une musique improvisée! Istr." (Lie, it is not improvised music!). The second copy says “Quelle blague! Je n'ai jamais improvise cette Valse [;] au contraire, elle est tout ce qu'il y a de compose [,] et non pas au Figaro mai [s] c'est chez moi à la maison. Istr." (What a joke! I never improvised this waltz; on the contrary, the waltz is all that composition is, and not at the Figaro, but at my home.). Additionally, the composer also noted the exact timing of the piece as 52 seconds. For these reasons, as well as the fact that the piece was composed around the same time as the duets (Three Easy Pieces and Five Easy Pieces) that Stravinsky had written for his children, it seems likely that this piece was composed (not improvised) for his own use in his household.

Example 4.1 Igor Stravinsky, Valse pour les enfants

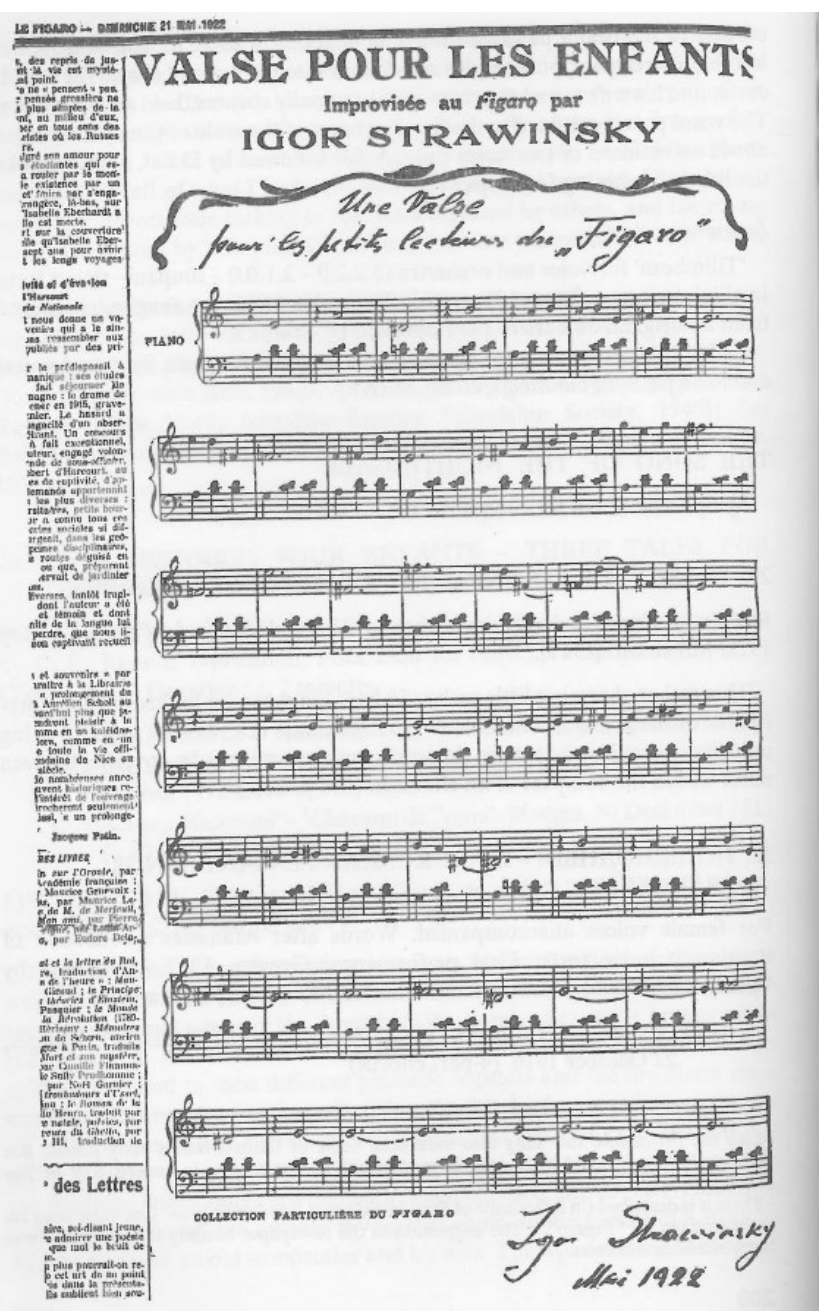


Valse pour le enfants is a very short piano piece, only 56 measures long, yet it is a gem of children's literature that pianists have almost completely forgotten. The structure of this piece can be divided into two main sections. Section A is from mm.1-37. Section B (or A') is from mm.38- 56.

The motif of the Valse is in a two-bar unit, which is the basis of the eight measures $(4+4)$ that make up the antecedent and consequent phrases.

Example 4.2 Igor Stravinsky, Valse pour les enfants, mm. 1-2

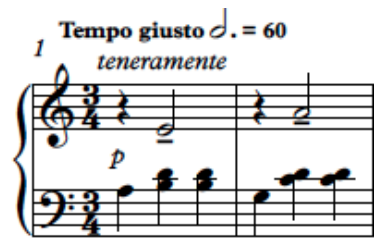

sempre leggieramente e stc

Used by permission.

Copyright by Boosey \& Hawkes, Inc.

Example 4.3 Igor Stravinsky, Valse pour les enfants, mm. 1-8

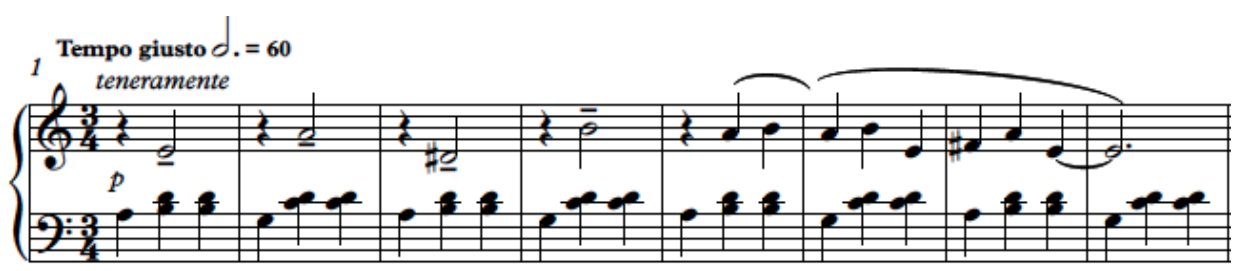

sempre leggieramente e stacc.

Used by permission.

Copyright by Boosey \& Hawkes, Inc.

According to Craft, the melodic source of Valse pour le enfants that was initially written as an alphabetical shorthand for repeated measures (A, B, C, D, E), was found on a sheet for the 
"Lied ohne Name" which is composed of two notations. ${ }^{33}$ The range of the melody is from Dsharp above middle $\mathrm{C}$ to top-space $\mathrm{G}$. The piece begins with the waltz rhythm in the bass line, followed by the melody with a tenuto marking on the second beat. For the left-hand part, Stravinsky writes in a two-bar pattern which is repeated in its entirety 28 times until the end. This "mechanical ostinato accompaniment" ${ }^{\prime 4}$ is a common compositional technique that Stravinsky utilizes in Valse des fleurs (1914), Valse pour les enfants (1916), and the Five Easy Pieces (1917, for duet with 'easy right-hand').

Example 4.4 Igor Stravinsky Valse pour les enfants

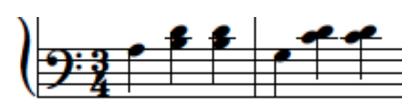

Used by permission. Copyright by Boosey \& Hawkes, Inc.

Stravinsky utilizes twentieth-century compositional techniques to construct this piece. Even though the tonality is not obviously established from the beginning of the piece, E minor serves as the tonal center in the right hand while the left-hand part alternates between A and G (See Example 4.4), which gives a sense of $\mathrm{G}$ as a tonal center, until the ending measure in which he uses a C major chord in second inversion with an added second. This left-hand writing style is also presented in the composer's later work Les cinq doigts (1921). Due to the limited range of notes being used in the composition, it is arguable that this work by Stravinsky shows some influence of Russian folk tunes as well as the use of a pentatonic scale. Moreover, a chromatic melody is also used to bring the line to the end of the phrase.

\footnotetext{
${ }^{33}$ Robert Craft, Stravinsky: Selected Correspondence Volume 1 (New York: Alfred A. Knopf, 1982), 413.

${ }^{34}$ Stephen Walsh, The Music of Stravinsky (Oxford: Clarendon Press, 1993), 62.
} 

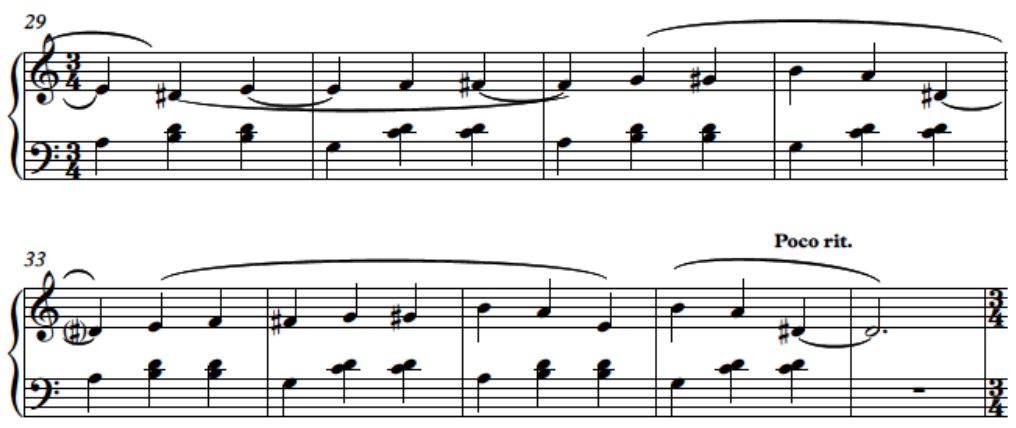

Used by permission.

Copyright by Boosey \& Hawkes, Inc.

Finally, in measure 50, Stravinsky resolves the D-sharp to the E tonal center and prolongs it above the rocking bass line for seven measures.

Valse pour les enfants is marked with a moderate waltz tempo with the dotted quarter note at 60 and is also required to play in a teneramente (tenderly) manner. In terms of rhythm, the composer utilizes a number of syncopated figurations and many ties over the bar lines in order to suspend the pitches and rhythm. Some examples can be seen in mm. 21-24 and mm. 2930, which creates not only musical interest but also technical demands.

Example 4.6 Igor Stravinsky, Valse pour les enfants, mm.21-24

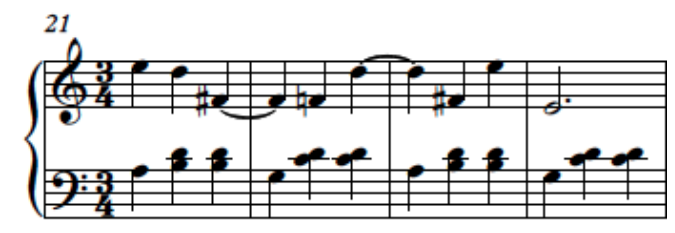

Used by permission. Copyright by Boosey \& Hawkes, Inc. 
Example 4.7 Igor Stravinsky, Valse pour les enfants, mm.29-30

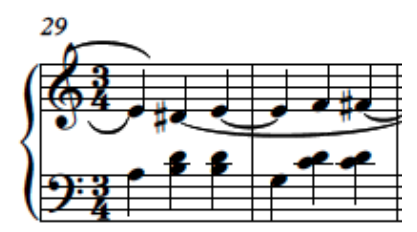

Used by permission. Copyright by Boosey \& Hawkes, Inc.

The pedagogical concerns in this piece center largely on the repetitive waltz rhythm in the left hand. It is recommended that the students securely practice their left hand part to get the rhythmic pattern securely in the motor memory so that they can focus on the right hand melody. Additionally, the left hand pattern, especially the first bar (see measure 29 in Example 6-6), potentially creates a fourth and third fingers independence issue, especially for young children or even adult students. Potential rhythmic issues in the right hand include ties over the bar lines and syncopation. One more challenging passage for young students with small hands may be in mm.9-10 and mirroring mm.11-12, which require the hand to span a seventh in order to make the melodic line as smooth as possible.

Valse pour les enfants is a worthy and appropriate introductory piece for early intermediate students first engaging with modern repertoire. It also exemplifies Stravinsky’s lighter texture and character. This is an ideal work for teachers to aid students, especially those who are young, in developing an ear and appreciation for this music, as well as to help train them to play with a light touch and "tenderly" as Stravinsky indicates. 


\section{CHAPTER FIVE}

\section{Quaderno Musicale di Annalibera (Musical Notebook for Annalibera) by}

\section{Luigi Dallapiccola (1904- 1975)}

Luigi Dallapiccola (1904-1975) — an Italian composer and pianist noteworthy for his lyrical twelve-tone compositions-was born in the territory of Pisino d'Istria in 1904. Pisino d' Istria was then part of the Austrian Empire as a result of political disputes. Later, in 1922, he moved to Florence where he studied composition and harmony in the Florence Conservatory. After attending a performance of Schoenberg's Pierrot Lunaire, he became interested in serialism, which later shaped his compositional development. His musical compositions evolved from a diatonic style to dodecaphony and total serialism. However, his approach to twelve- tone composition seems more romantic than anti-romantic, as he is always looking for a "dramatic subject-matter" to suit his chosen vocabulary. ${ }^{35}$ His musical compositions were greatly influenced by Claude Debussy, Arnold Schoenberg, Ferruccio Busoni, Alban Berg, and Anton Webern. ${ }^{36}$ Most scholars agree that Luigi Dallapiccola is one of the most accomplished twelvetone composers. His output is comprised of a variety of frequently performed and highly respected works, including ballets, choral music, concerti, film scores, piano music, song cycles, operas, and chamber pieces. In addition, he enjoyed international fame as a lecturer, teacher,

\footnotetext{
${ }^{35}$ Frederik Goldbeck, Twentieth Century Composers Volume IV: France, Italy, and Spain (London: Weidenfeld and Nicolson, 1974), 117.

${ }^{36}$ John C.G. Waterhouse and Virgilio Bernandoni, “Dallapiccola, Luigi.” In Grove Music Online. http://www.oxfordmusiconline.com/subscriber/article/grove/music/07081?q=luigi+dallapiccola\&search=quick\&pos $=1 \& \_s t a r t=1 \#$ firsthit $($ accessed September 13, 2014)
} 
author, and member of the national academies of arts in the U.S., France, and England. ${ }^{37}$

Dallapiccola himself was a trained pianist as well as a piano teacher. His piano studies began at the age of eight under Maestro Pietro Pischiutta, a local piano teacher. ${ }^{38}$ Piano was his first musical instrument. Later, in March 1917 during his family's exile in Graz, Austria, his musical world was broadened to include various genres of music, especially vocal music by Verdi and Wagner. He returned to Pisino in 1919 and entered Conservatorio Luigi Cherubini in Florence, Italy, in 1922. There he received his degree in piano in 1924 and in composition in 1931, respectively. Dallapiccola was also appointed as a faculty member at Conservatorio Luigi Cherubini in $1934 .^{39}$ He taught piano lessons for over 30 years. ${ }^{40}$ Additionally, from 1920-49, Dallapiccola appeared in duos as an accompanist, as well as serving as an accompanist for an American dancer, La Méri. ${ }^{41}$

Despite his strong background as a pianist, Dallapiccola wrote only five works for piano. Three of them are for piano solo. They are Sonatina canonica in E-flat Major on 'Capricci' of Niccolò Paganini (1943), Tre episodi dal balletto 'Marsia' (1949), and Quaderno Musicale di Annalibera (1952). The other two pieces are for ensemble: Musica per tre pianoforte (1935) and

\footnotetext{
${ }^{37}$ Brian Alegant, The Twelve-Tone Music of Luigi Dallapiccola (Rochester: University of Rochester Press, 2010) 1.

${ }^{38}$ Raymond Fearn, The Music of Luigi Dallapiccola. (Rochester: University of Rochester Press, 2003), 3.

${ }^{39}$ Rachel Elice Mann, “Tonal references in Luigi Dallapiccola's Quarderno Musicale Di Annalibera” (MM thesis, Texas Tech University, 2002), 6.

${ }^{40}$ Shu-Ting Yang, "Salute to Bach: Modern Treatments of Bach- Inspired Elements in Luigi Daallapiccola's Quarderno Musicale di Annaliver and Heitor Villa- Lobos' Bachianas Brasileiras No.4" (DMA diss., The University of Cincinnati, 2007), 20.

${ }^{41}$ Rachel Elice Mann, "Tonal references in Luigi Dallapiccola's Quarderno Musicale Di Annalibera" (MM thesis, Texas Tech University, 2002), 6.
} 
Piccolo concerto per Muriel Couvreux (1939-41). ${ }^{42}$

Dallapiccola composed the Quaderno Musicale di Annalibera (Musical Notebook for Annalibera) in 1952 for the Pittsburgh International Contemporary Music Festival. ${ }^{43} \mathrm{He}$ dedicated this work to Annalibera (b. 1944) who was just eight years old on December 1, 1952. Anna Libera Dallapiccola is Luigi Dallapiccola's only daughter with his wife, Laura Coen Luzzato (1911-1995). Fearn mentioned that this set is not intended for pedagogical purposes. ${ }^{44}$ Perhaps this is because Anna Libera Dallapiccola (or Annalibera) was just eight at that time and the difficulty shown in this piece is typically not suitable for an eight-year-old girl's pianistic ability. The middle name of Anna, Libera, comes from the word "liberation," as she was born in 1944, the year Florence was liberated. ${ }^{45}$ (Anna Libera Dallapiccola became an archeologist and is a former Professor of Indian Art at the South Asia Institute at Heidelberg, Germany and specialist in Asian Arts and Doctrine of India. Today, she is a scholar in Asian and Indian art and is an Honorary Professor of Fine Arts at the University of Pennsylvania and the University of Edinburgh.)

Later in 1953, Dallapiccola revised Quaderno Musicale di Annalibera as a full orchestra version entitled Variazione per orchestra, commissioned by the Louisville (Kentucky)

\footnotetext{
${ }^{42}$ Shu-Ting Yang, "Salute to Bach: Modern Treatments of Bach- Inspired Elements in Luigi Daallapiccola's Quarderno Musicale di Annaliver and Heitor Villa- Lobos' Bachianas Brasileiras No.4" (DMA diss., The University of Cincinnati, 2007), 20.

${ }^{43}$ Miguel Roig-Francoli. Understanding Post-Tonal Music. New York, NY: McGraw-Hill, 2008. 174

${ }^{44}$ Raymond Fearn. The Music of Luigi Dallapiccola. (Rochester: University of Rochester Press, 2003), 157-159.

${ }^{45}$ Chamber Music Today, Luigi.” In Chamber Music Today. http://chambermusictoday.blogspot.com/2008/03/dallapiccola-on-childrens-rights-and.html (accessed September 13, 2014)
} 
Symphony Orchestra. ${ }^{46}$ The solo piano version consists of eleven short pieces in which the composer has incorporated twelve-tone techniques. Dallapicolla indicates that it is to be performed in its entirety according to his directions printed in the front material of the score: 'Non è consentita, per nessuna ragione, l'esecuzione dei singoli pezzi: l'opero potrà essere eseguita soltanto nella sua compiutezza." (It is not permitted, under any circumstances, the execution of the individual pieces: the work will be performed only in its entirety).

According to the introductory page in the score, the overall structure of these eleven short eleven pieces forms a large-scale composition comprised of five sections. The first section is the introduction, "Simbolo." The next four sections are organized into groups of two and three pieces: "Accenti" and "Contrapunctus Primus"; "Linee" and "Contrapunctus Secondus"; Fregi and Andantino Amoroso e contrapunctus tertius; and Ritmi, Colore, and Ombre. The last section is an epiloque, "Quartina". The title Quaderno Musicale di Annalibera recalls the Baroque Notenbüchlein für Anna Magdalena Bach (The Notebook for Anna Magdalena Bach). The composer also utilizes various techniques in this work that recall the Baroque, such as a BA-C-H motif, polyphony, canonic materials, binary dance forms, and contrapuntal writing. Additionally, the pairing of movements recalls Bach's The Art of Fugue ${ }^{47}$ as well as the Preludes and Fugues. ${ }^{48}$ Quaderno Musicale di Annalibera is among the four major compositions by

\footnotetext{
${ }^{46}$ Sue Burnett Petito, "The Piano Works of Luigi Dallapiccola (1904-1975): An analysis for performance" (Ph. D. diss, New York University, 1989), 285.

${ }^{47}$ Raymond Fearn. The Music of Luigi Dallapiccola. (Rochester: University of Rochester Press, 2003), 157.

${ }^{48}$ Shu-Ting Yang, "Salute to Bach: Modern Treatments of Bach- Inspired Elements in Luigi Dallapiccola's Quarderno Musicale di Annalibera and Heitor Villa- Lobos' Bachianas Brasileiras No.4" (DMA diss., The University of Cincinnati, 2007), 18.
} 
Dallapiccola that employ the B-A-C-H motive - Quaderno Musicale di Annalibera, Tre Laudi, Canti di Liberazione, and Concerto per la notte di Natale dell' anno 1956.

The B-A-C-H motif here is mostly in variations of the form of the set $(0,1,2,3)$, which is mostly in half steps, both ascending and descending (See Example 5a).

Example 5a Luigi Dallapiccola Quaderno Musicale di Annalibera: "B-A-C-H motif and its variants"

The Traditional B-A-C-H Motif

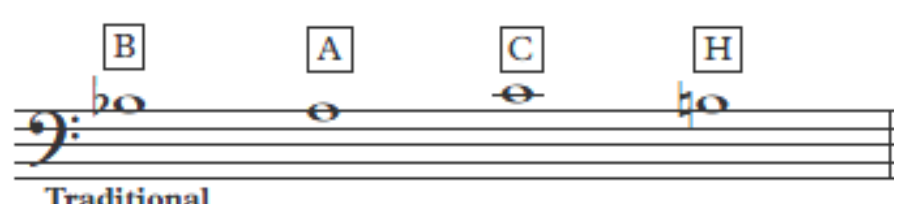

Traditional

The transposed B-A-C-H motif in Luigi Dallapiccola Quaderno Musicale di Annalibera from the row P0

ORIGINAL
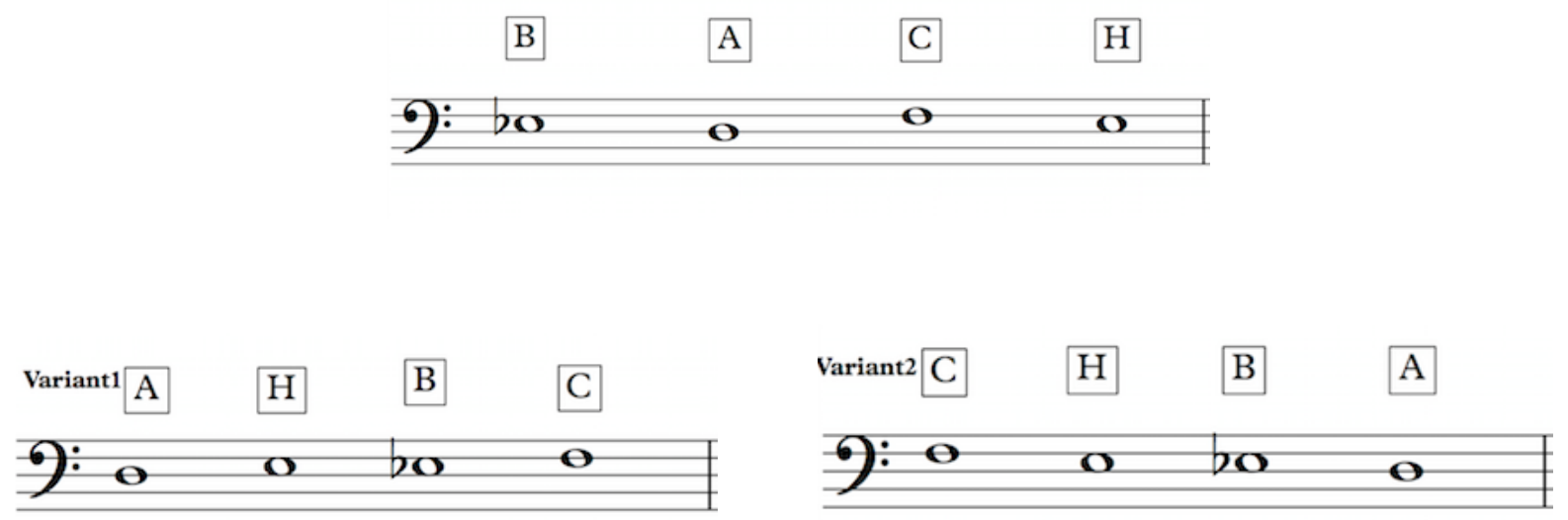

In addition to Luigi Dallapiccola's Quaderno Musicale di Annalibera, there are many more pieces featuring the use of the B-A-C-H motif. Those pieces include F. Liszt's Fantasy and Fugue on the Theme B-A-C-H, N. Rimsky-Korsakov's Variations on BACH for piano, and F. Poulenc's Valse-improvisation sur le nom BACH for piano. 
Quaderno Musicale di Annalibera is unified by the use of the same tone row in each of the eleven pieces. The composer also utilizes the implication of thematic links between some of these movements. However, the character of each piece varies from peaceful to brutal to mysterious. Following is the complete matrix of the twelve-tone row and its permutations featured in Quaderno Musicale di Annalibera.

Example 5b: Luigi Dallapiccola, Quaderno Musicale di Annalibera tone row ${ }^{49}$

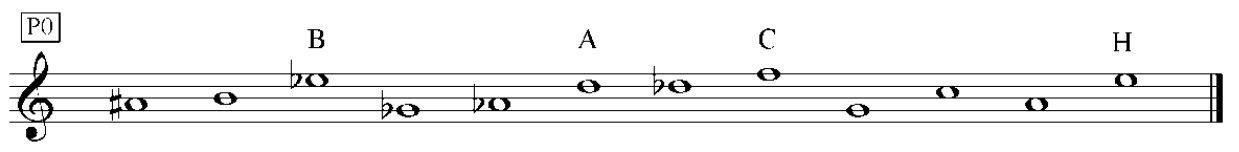

Example 5c: Luigi Dallapiccola Quaderno Musicale di Annalibera tone row and its permutations

\begin{tabular}{|c|c|c|c|c|c|c|c|c|c|c|c|c|c|}
\hline & I 0 & I 1 & I 5 & I 8 & I 10 & I 4 & I 3 & I 7 & I 9 & I 2 & I 11 & I 6 & \\
\hline P 0 & A\# & B & $\mathrm{Eb}$ & $\mathrm{Gb}$ & $\mathrm{Ab}$ & $\mathrm{D}$ & $\mathrm{Db}$ & $\mathrm{F}$ & G & $\mathrm{C}$ & $\mathrm{A}$ & $\mathrm{E}$ & R 0 \\
\hline P 11 & A & A\# & $\mathrm{D}$ & $\mathrm{F}$ & G & $\mathrm{Db}$ & $\mathrm{C}$ & $\mathrm{E}$ & $\mathrm{Gb}$ & $\mathrm{B}$ & $\mathrm{Ab}$ & $\mathrm{Eb}$ & R 11 \\
\hline P 7 & $\mathrm{~F}$ & $\mathrm{~Gb}$ & A\# & $\mathrm{Db}$ & $\mathrm{Eb}$ & A & $\mathrm{Ab}$ & $\mathrm{C}$ & $\mathrm{D}$ & G & $\mathrm{E}$ & B & R 7 \\
\hline P 4 & $\mathrm{D}$ & $\mathrm{Eb}$ & G & $\mathrm{A} \#$ & $\mathrm{C}$ & $\mathrm{Gb}$ & $\mathrm{F}$ & A & B & $\mathrm{E}$ & $\mathrm{Db}$ & $\mathrm{Ab}$ & $\mathrm{R} 4$ \\
\hline P 2 & C & $\mathrm{Db}$ & $\mathrm{F}$ & $\mathrm{Ab}$ & A\# & $\mathrm{E}$ & $\mathrm{Eb}$ & G & A & $\mathrm{D}$ & B & $\mathrm{Gb}$ & $\mathrm{R} 2$ \\
\hline P 8 & $\mathrm{~Gb}$ & $\mathrm{G}$ & B & $\mathrm{D}$ & $\mathrm{E}$ & $\mathrm{A} \#$ & A & $\mathrm{Db}$ & $\mathrm{Eb}$ & $\mathrm{Ab}$ & $\mathrm{F}$ & $\mathrm{C}$ & R 8 \\
\hline P9 & $\mathrm{G}$ & $\mathrm{Ab}$ & $\mathrm{C}$ & $\mathrm{Eb}$ & F & B & $\mathrm{A \#}$ & $\mathrm{D}$ & $\mathrm{E}$ & A & $\mathrm{Gb}$ & $\mathrm{Db}$ & R 9 \\
\hline P 5 & $\mathrm{~Eb}$ & E & $\mathrm{Ab}$ & B & $\mathrm{Db}$ & G & $\mathrm{Gb}$ & A\# & $\mathrm{C}$ & $\mathrm{F}$ & $\mathrm{D}$ & A & R 5 \\
\hline P 3 & $\mathrm{Db}$ & $\mathrm{D}$ & $\mathrm{Gb}$ & $\mathrm{A}$ & $\mathrm{B}$ & $F$ & $\mathrm{E}$ & $\mathrm{Ab}$ & A\# & $\mathrm{Eb}$ & $\mathrm{C}$ & $\mathrm{G}$ & R 3 \\
\hline P 10 & $\mathrm{Ab}$ & A & $\mathrm{Db}$ & $\mathrm{E}$ & $\mathrm{Gb}$ & $\mathrm{C}$ & B & $\mathrm{Eb}$ & $\mathrm{F}$ & A\# & G & D & R 10 \\
\hline P 1 & B & $\mathrm{C}$ & $\mathrm{E}$ & G & A & $\mathrm{Eb}$ & $\mathrm{D}$ & $\mathrm{Gb}$ & $\mathrm{Ab}$ & $\mathrm{Db}$ & A\# & $F$ & $\mathrm{R} 1$ \\
\hline \multirow[t]{2}{*}{ P 6} & $\mathrm{E}$ & $\mathrm{F}$ & $\mathrm{A}$ & $\mathrm{C}$ & $\mathrm{D}$ & $\mathrm{Ab}$ & G & B & $\mathrm{Db}$ & $\mathrm{Gb}$ & $\mathrm{Eb}$ & A\# & R 6 \\
\hline & RI 0 & RI 1 & RI 5 & RI 8 & RI 10 & RI 4 & RI 3 & RI 7 & RI 9 & RI 2 & RI 11 & RI 6 & \\
\hline
\end{tabular}

${ }^{49}$ Raymond Fearn. The Music of Luigi Dallapiccola. (Rochester: University of Rochester Press, 2003), 159. 
In Quaderno Musicale di Annalibera, each piece could be considered an introduction to selected aspects of twentieth-century music or as studies of the various musical compositional techniques, according to each topic described in their respective titles. Due to the difficulty of these pieces, it is suggested that students learn these pieces in the following progressive order, from simplest to most challenging: 1) “Linee," 2) “Colore," 3) “Fregi," 4) "Quartina," 5) "Contrapunctus Primus," 6) "Contrapunctus Secondus," 7) “Andantino Amoroso e Contrapunctus Tertius," 8) “Simbolo," 9) “Accenti," 10) “Ombre," and 11) "Ritmi” The rationale for this order is determined by the tempo of each piece and the rhythmic, reading, and pianistic complexity. Moreover, it is suggested that students approach this work after at least some experience in reading three staves for example in a work such as Debussy's "Canopes" from Preludes, Book II.

Following is a brief survey of each movement of Dallapicolla's Quaderno Musicale di Annalibera describing structure, compositional techniques and pedagogical issues.

\section{"Simbolo"}

The overall structure of "Simbolo" ("Symbol") -through the use of tempo, articulation, and register-could be divided into three sections: A, B, A' (see Example 5.1.1). 
Example 5.1.1 Luigi Dallapiccola Quaderno Musicale di Annalibera: I. “Simbolo"

\begin{tabular}{|l|c|c|c|}
\hline FORM: & A & B & A' \\
\hline Measures: & $1-16$ & $17-36$ & $37-46$ \\
\hline Tempi: & $\delta=84$ & $\delta=92-96$ & $\delta=84$ \\
\hline Articulations: & Staccatissimo & Legato & Staccatissimo \\
\hline Registers: & Low-Middle & Middle-High & Low-Middle \\
& & & \\
\hline
\end{tabular}

"Simbolo" is based on the following tone-row forms: P 0 (mm.1-5 and mm.42-46), R 1 (m. 6), P 7 (m.7 and mm.14-16), R 7 (mm.8-10), I 8 (mm. 12-14), segment of R 6 (m.16), R I0 (mm.17-20), R 2 (mm.21-25), P 9 (mm. 25, 27, and 29-32), R 9 (mm. 26 and 28), and I 10 (mm.33-37). ${ }^{50}$ The arrangement of P, R, and I row forms in the beginning of the piece as well as the row forms I, R, and P at the end of the piece give a sense of symmetry to "Simbolo" (see Example 5.1.2).

Example 5.1.2 Luigi Dallapiccola Quaderno Musicale di Annalibera: I. "Simbolo"

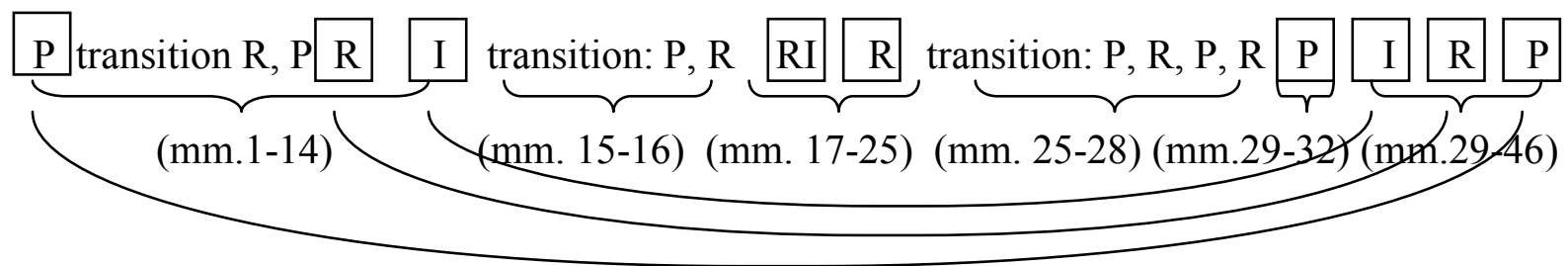

\footnotetext{
${ }^{50}$ Sue Burnett Petito, "The Piano Works of Luigi Dallapiccola (1904-1975): An analysis for performance" (PhD diss., New York University, 1989), 372.
} 
Tonal references appear in "Simbolo" even though it is a serial work. The structure and nature of the rows contain the following characteristics: a combination of two hexachords (e.g., P0 consists of the first, second, third, and fourth notes of the first hexachord (B major seventh chord) and the last four notes of the second hexachord (an A minor seventh chord), repeated notes, pedal points, and linear chromatic motion in long note values, all of which create a sense of tonality throughout the piece.

\section{Example 5.1.3 Luigi Dallapiccola Quaderno Musicale di Annalibera: I. "Simbolo"}

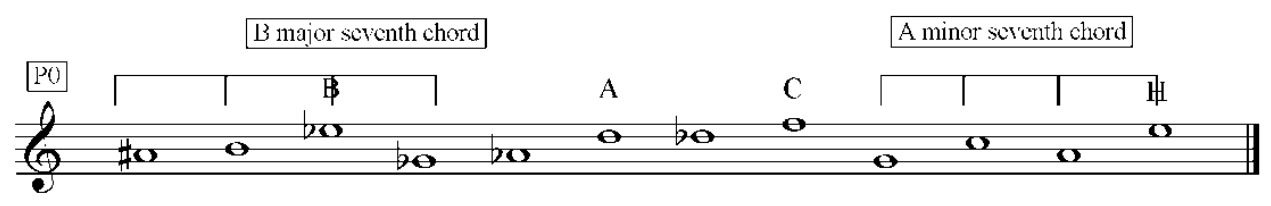

In terms of texture, contrapuntal writing in a two- and three-voice texture as well as a chordal texture predominates throughout the piece. The ostinato bass is also presented with clear sectional divisions: the A section begins with the ostinato bass in the left hand, whereas the same rhythmic idea, which is similar to murky bass, is taken over by the right hand in section B.

"Simbolo" is unified through almost continuous eighth-note figures, the same articulations, registration and the use of the original row form. Moreover, a return of the $\mathrm{A}^{\prime}$ section, which uses the original B-A-C-H motive in the upper-most voice, creates a sense of symmetry to the piece.

Allusions to the B-A-C-H motive occur throughout "Simbolo" in several row forms and permutations. Dallapiccola relates each motive to the form of the row. For instance, if an inversion of the row form is utilized, the B-A-C-H motive will appear in inversion as well.

Due to the fact that the BACH motive is an inversionally-symmetrical set $(0,1,2,3)$, the retrograde and the inversion are the same (transposed), as are the prime and the 
retrograde-inversion forms. This B-A-C-H motive also appears in shorter note values as part of a chordal texture. This occurrence is not obvious visually and is not easily audible because of the compression of the rhythmic structure within the notes that make up the motive. The other forms of permutations, such as a circulation and reordering of the B-A-C-H motive, also occur simultaneously with the motive itself. Those permutations can be categorized into two types: a chromatically conjunct line and a line with two black keys and two white keys (see Example 5.1.4).

Example 5.1.4 Luigi Dallapiccola Quaderno Musicale di Annalibera: I. "Simbolo" mm. 2-5 and 25

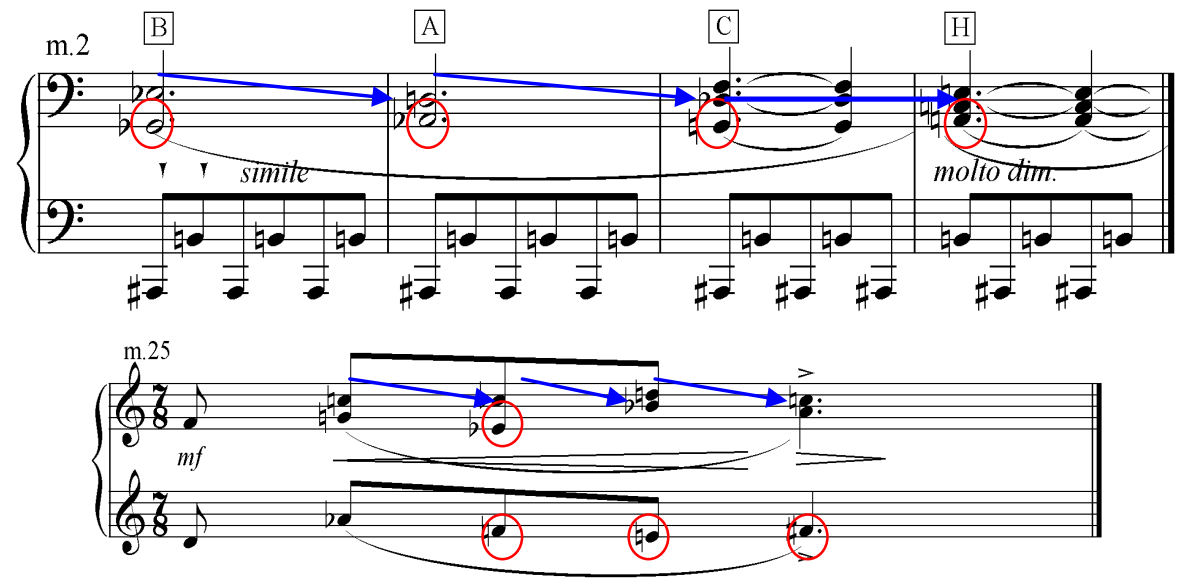

Used by permission.

Copyright by Sugarmusic S.p.A. - Edizioni Suvini Zerboni, Milano (Italy)

A sense of rhythmic pulse is established by the steady ostinato eighth-note bass in the opening of "Simbolo." However, we also observe a frequent change of time signatures, along with a tempo change in the middle (B) section.

The dynamic contour of the piece has its loudest point as $m f$ in $\mathrm{mm} .2$ and 25 and its softest as $p p p$ in mm. 15-16. Each section presents a different dynamic level. Nonetheless, a gradual change of dynamics is also indicated. The B-A-C-H motive in long note values is always marked to be louder than its accompaniment. A structural symmetry of the piece also appears in the lowest and the highest points registrally. The lowest point of this piece occurs in the 
beginning as well as the end as an ostinato bass, while the highest point takes place in $\mathrm{m} .15$ as a transition to the middle (B) section.

The B-A-C-H motive plays a significant role in the structural unification of "Simbolo." Despite the serial writing and frequent change of meters, this piece also features some characteristics of Baroque music: an ostinato bass and contrapuntal writing. Moreover, this work serves as an initial study of the twelve-tone technique that Dallapiccola used in his Canti di Liberazione (Songs of Liberation) in 1955. Simbolo employs limited dimensions in regard to length, restricted motivic elements, and only a few usages of the twelve-tone row transposition.

Pedagogical considerations in learning this movement include the changing meter and irregular meter as seen in measures 15 (3/4) and 16 (11/16); articulation; voicing the B-A-C-H motif audibly; and the use of the pedals as marked. Also challenging is the control of sound within the quiet dynamics. "Simbolo" represents an inspiring aid for piano students in exploring and understanding the musical idioms of $20^{\text {th }}$ century twelve-tone music at the early advanced level.

\section{"Accenti"}

"Accenti" (Accents) is the second piece of the set and paired with the third piece "Contrapunctus Primus," which has a contrasting character. This movement requires energetic playing for volume, articulation, and rhythm and, as the name suggests, a variety of accents. "Accenti" is written in a very brief binary form. Section A is eight measures, and section B lasts from measure nine to the end.

The tone rows utilized in "Accenti" are P 0 (mm. 1-2 and 5-6), I 8 (mm. 3-4, 11-12, and 15-16), I 10 (mm. 7-8), P 4 (mm. 9-10), and P 2 (mm. 13-14). The two-bar phrasing is important 
here, as it lays out the complete usage of each tone row in each two-bar unit. It is also noticeable that Dallapicola uses prime rows in the first half of every four-bar unit (i.e., mm. 1-2, 5-6, 9-10, and 13-14) and uses inverted rows in the second half (i.e., mm. 3-4, 7-8, 11-12, and 15-16). ${ }^{51}$

In terms of texture, "Accenti" has a somewhat dense harmony and thick texture throughout the piece. Dallapiccola mostly writes five-note set chords (i.e., 0, 1, 2, 3, 4) at the same time.

Example 5.2.1 Luigi Dallapiccola Quaderno Musicale di Annalibera: II. "Accenti” mm.1-2

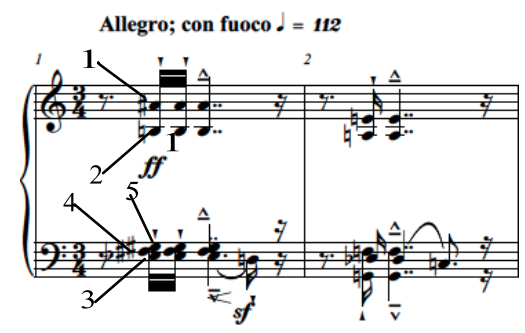

Used by permission.

Copyright by Sugarmusic S.p.A. - Edizioni Suvini Zerboni, Milano (Italy)

The B-A-C-H motif is also used in this movement, noticeably in the moving voice that is completed in the two bar units. However, this is not as obvious as in "Simbolo". 52

The precision of playing the dotted rhythm as well as the articulation is very important in this movement. In terms of rhythm, the composer notated this piece in a 3/4 time signature. However, rather than a straight, simple rhythm, Dallapiccola uses the anacrusis, dotted rhythm, and syncopated rhythmic groupings throughout this piece. Dallapiccola also uses several different types of expressive and articulation markings. There are three main types of articulation

\footnotetext{
${ }^{51}$ Sue Burnett Petito, "The Piano Works of Luigi Dallapiccola (1904-1975): An analysis for performance" (PhD diss., New York University, 1989), 372.

${ }^{52}$ Ibid., 304.
} 
used throughout the piece. The first is staccatissimo. The second is the martellato accent and martellato with tenuto. The third is the accent and the accent with the tenuto sign.

Example 5.2.2 Luigi Dallapiccola Quaderno Musicale di Annalibera: II. “Accenti” mm.1-2, 3-4, and 5-6"
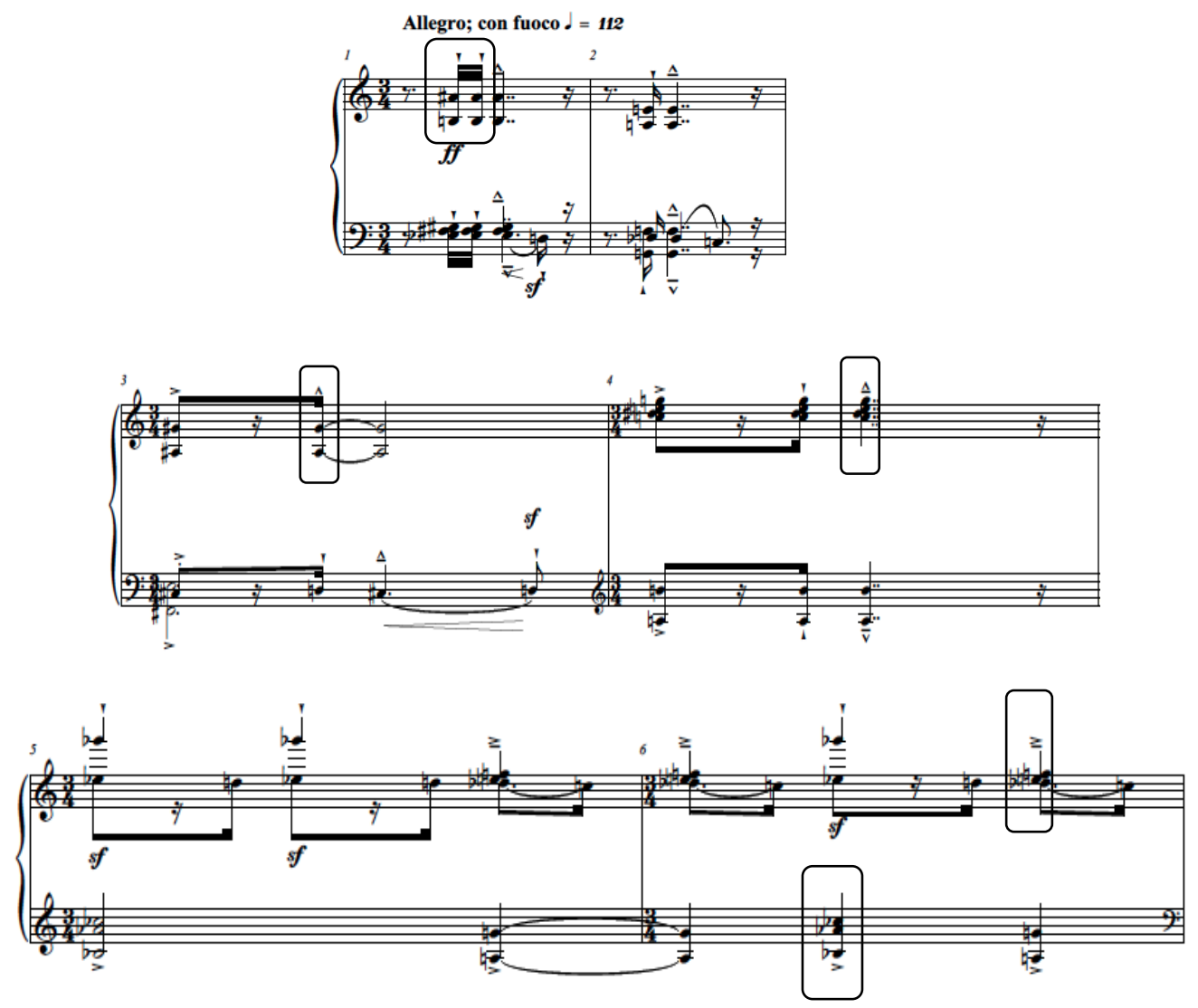

Used by permission.

Copyright by Sugarmusic S.p.A. - Edizioni Suvini Zerboni, Milano (Italy)

In terms of dynamics, this brief movement is marked $f f$ from the beginning to the end with some use of sforzandi, especially in the last five measures. The use of the crescendo sign in this piece is often from one note to the next, which creates a particularly dramatic effect. 
Example 5.2.3 Luigi Dallapiccola Quaderno Musicale di Annalibera: II. “Accenti” mm.1-2 and 3-4
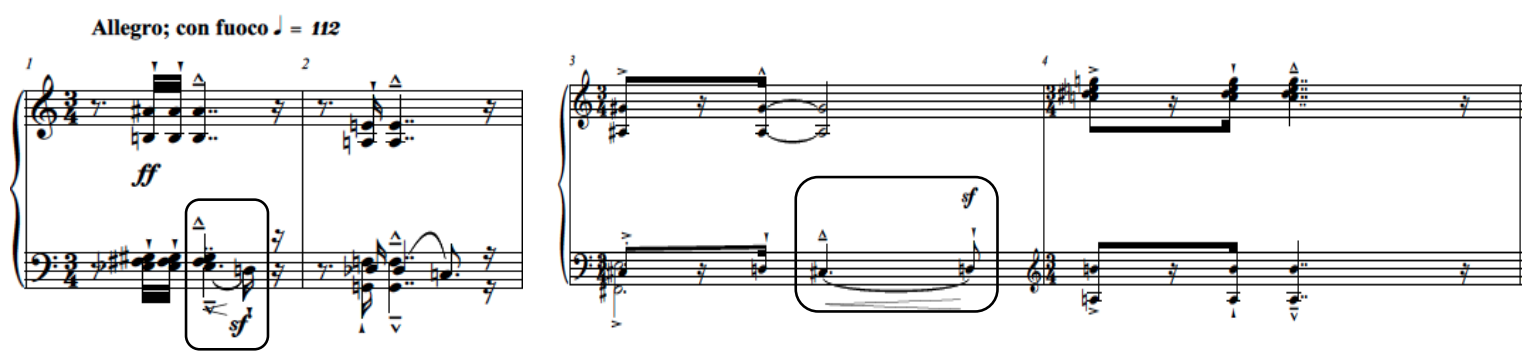

Used by permission.

Copyright by Sugarmusic S.p.A. - Edizioni Suvini Zerboni, Milano (Italy)

The first major pedagogical concern in this piece is the ability to play and delineate the different kinds of articulation and accents, as well as to maintain the energy throughout the movement. The second is the rhythmic accuracy of the dotted rhythm. Thirdly, the interval writing in this piece, such as that seen in measure nine, can be challenging for students with small hands. This movement can also be categorized at the early advanced level.

\section{"Contrapunctus Primus"}

This piece complements the preceding “Accenti.” It is smooth, calm, and lyrical as a resolution to the extreme tension in the previous movement. The structure of "Contrapunctus Primus" (First Counterpoint) is also in binary form. It is a canon at the unison. The A section spans from measures 1 to 8, while the B section lasts from measures 9-18 (two measures longer than the A section). The notation here is quite complicated for students who are having their first experience with three staves. There are several occurrences in which the melodic line is divided over the three voices. 
Example 5.3.1 Luigi Dallapiccola Quaderno Musicale di Annalibera: III. “Contrapunctus Primus" mm.11-12

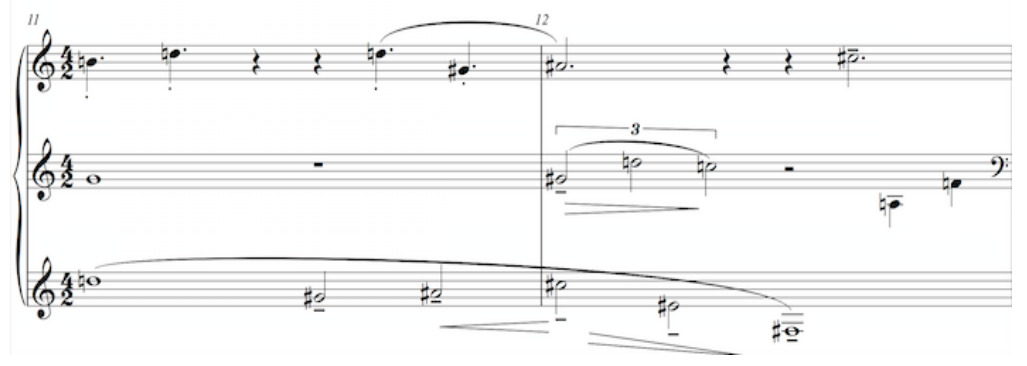

Used by permission.

Copyright by Sugarmusic S.p.A. - Edizioni Suvini Zerboni, Milano (Italy)

The texture in "Contrapunctus Primus" is polyphonic and intertwined like a fabric, with the shifts and changes being very subtle in nature. In terms of the tonal structure of the piece, the composer has a different way of executing each tone row throughout. Instead of writing each note in every voice vertically as in the "Accenti" (see Example 5.3.3a and 3b), he unfolds each note in certain rows in each voice horizontally and independently. The following diagram illustrates the tone rows utilized. ${ }^{53}$

${ }^{53}$ Sue Burnett Petito, "The Piano Works of Luigi Dallapiccola (1904-1975): An analysis for performance" (PhD diss., New York University, 1989), 310. 
Example 5.3.2 Luigi Dallapiccola Quaderno Musicale di Annalibera: III. "Contrapunctus Primus"

\begin{tabular}{|c|c|}
\hline Measures: & Row \\
\hline $1-4$ & $\begin{array}{l}\text { Voice 1: P } 1 \\
\text { Voice 2: P } 1\end{array}$ \\
\hline $5-8$ & $\begin{array}{l}\text { Voice 1:R } 3 \\
\text { Voice 2: R } 3\end{array}$ \\
\hline $9-12$ & $\begin{array}{l}\text { Voice 1+3: RI } 8 \\
\text { Voice 2: R } 6\end{array}$ \\
\hline $13-18$ & $\begin{array}{l}\text { Voice } 1 \text { and 2: P } 4 \\
\text { Voice } 3 \text { and 4: I } 0\end{array}$ \\
\hline
\end{tabular}

Example 5.3.3a Luigi Dallapiccola Quaderno Musicale di Annalibera: III. "Contrapunctus Primus"

mm.1-4

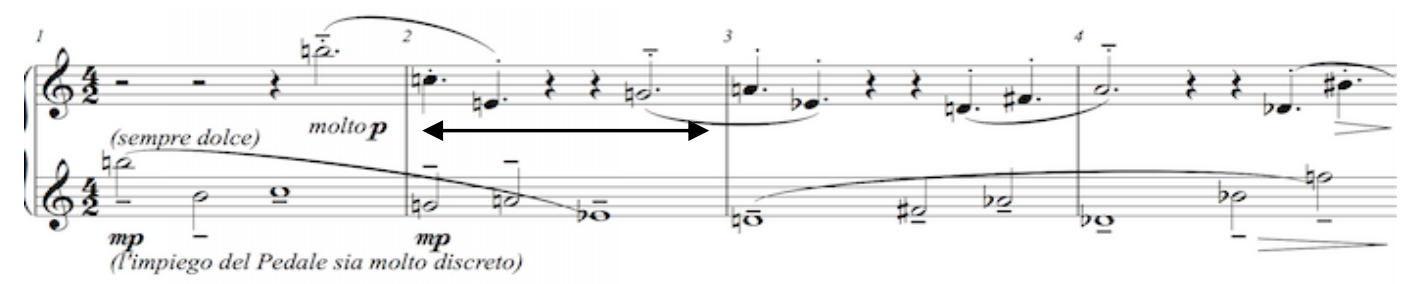

Used by permission.

Copyright by Sugarmusic S.p.A. - Edizioni Suvini Zerboni, Milano (Italy) 
Example 5.3.3b Luigi Dallapiccola Quaderno Musicale di Annalibera: II. “Accenti” mm.1-4

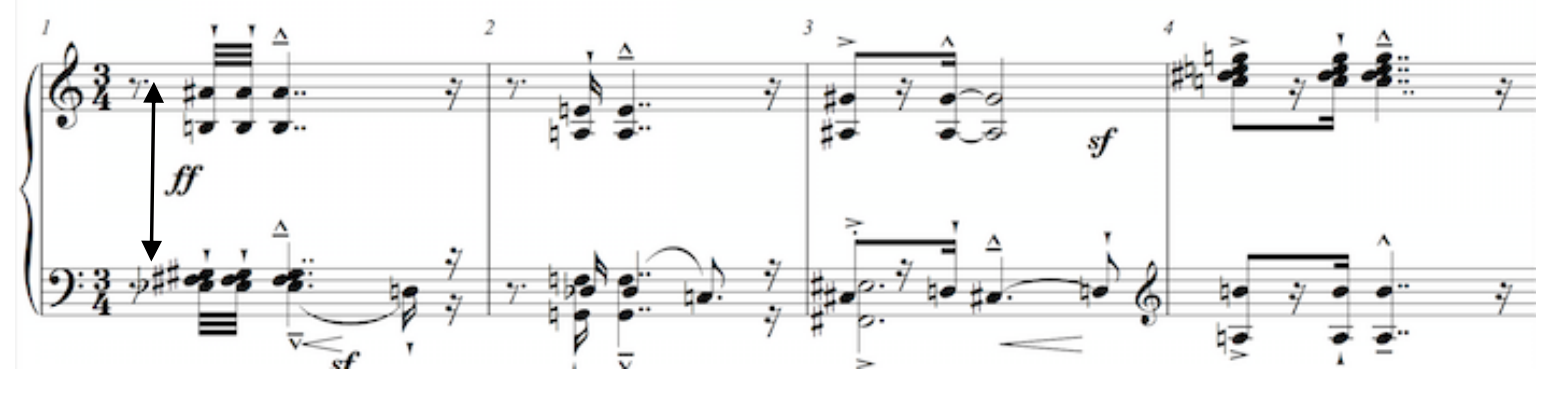

Used by permission.

Copyright by Sugarmusic S.p.A. - Edizioni Suvini Zerboni, Milano (Italy)

The B-A-C-H motif in this movement is presented quite straight forwardly according to the original order of each tone row and the variations (i.e., four chromatic notes). If the original row is used, the B-A-C-H motif will be found on pitches 3, 6, 7, and 10 as a four-note chromatic set. ${ }^{54}$ Considering the fact that they are not immediately next to each other, but have multiple notes in between, it will likely be challenging for the listener to recognize the theme aurally. On the other hand, the rhythmic pattern here helps the BA-C-H motif to be heard more easily, as the notes are placed at the end of the group as well as the beginning of each group.

Example 5.3.4 Luigi Dallapiccola Quaderno Musicale di Annalibera: III. “Contrapunctus Primus” mm.1-4

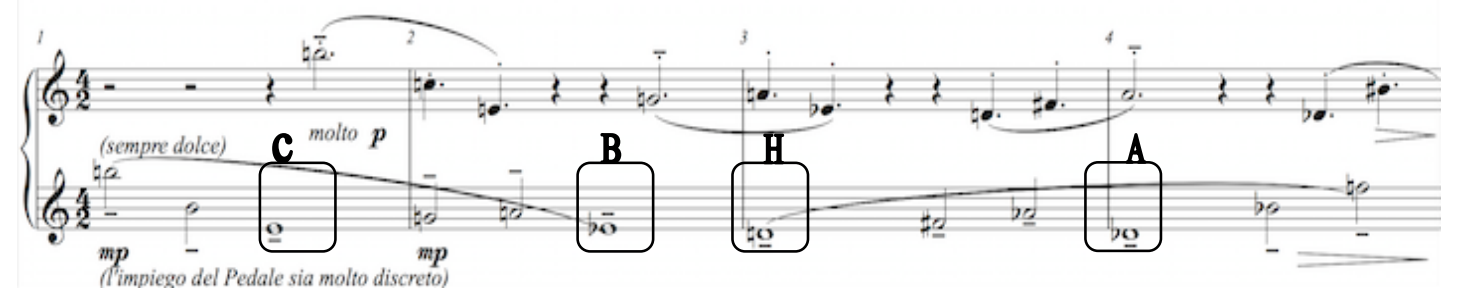

Used by permission.

Copyright by Sugarmusic S.p.A. - Edizioni Suvini Zerboni, Milano (Italy)

\footnotetext{
${ }^{54}$ Sue Burnett Petito, "The Piano Works of Luigi Dallapiccola (1904-1975): An analysis for performance" (Ph. D. diss, New York University, 1989), 310 and 313.
} 
The time signature here is quite simple in $4 / 2$, and the note values are not complicated. The dynamics follow each independent voice and there is some variety of articulation in this work, with the majority of it requiring good legato (highlighted by the use of the tenuto markings) contrasted with portato. Similar to the dynamics, each voice requires different articulation. Examples are portato, staccato, legato, and tenuto.

Pedagogical concerns in this movement are the required independence of the hands and the execution and voicing of each dynamic and articulation distinctively and audibly, which may be challenging for students who have less experience in playing contrapuntal repertoire. Maintenaning of the peaceful, stable, and lyrical nature of this movement from the beginning to the end poses further challenge. This piece can be categorized at the early advanced level.

\section{"Linee"}

The next pair of movements are "Linee" (Lines) and "Contrapunctus Secondus" (Second Counterpoint); "Linee" is, again, a contrast and complement to "Contrapunctus Secondus." The difference here is that the character of these two movements is in the opposite order when compared with the previous pair. "Linee" is a two-voice texture that stresses legato playing. The overall structure is a binary form: section A lasts from measures 1-5 and section B is from measures 6-10. The phrasing is non-traditional with five-measure phrases for each section of this question-and-answer pair. Dallapiccola begins the piece with the accompaniment in the right hand first which he then switches to the left hand in the B section. The eighth-note rocking accompaniment paired with sustained notes is similar to the writing in "Simbolo" and is one of the elements that serves to unify this set of pieces. 
Example 5.4.1a Luigi Dallapiccola Quaderno Musicale di Annalibera: I. "Simbolo" mm.1-4

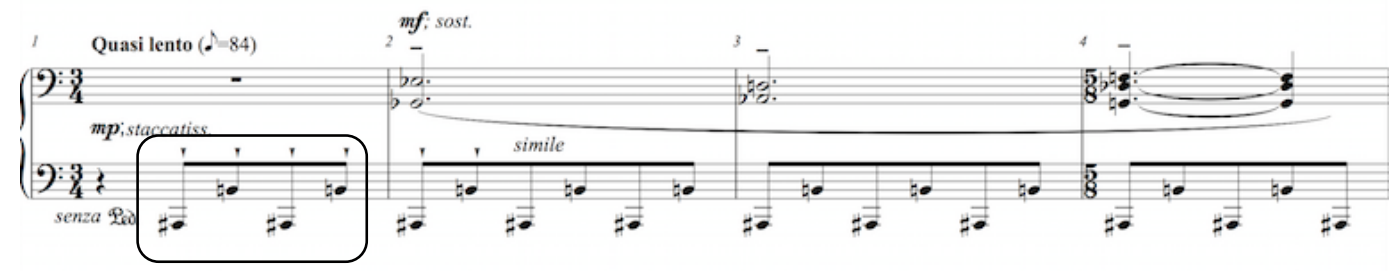

Used by permission.

Copyright by Sugarmusic S.p.A. - Edizioni Suvini Zerboni, Milano (Italy)

Example 5.4.1b Luigi Dallapiccola “Quaderno Musicale di Annalibera: IV. Linee” mm.1-4

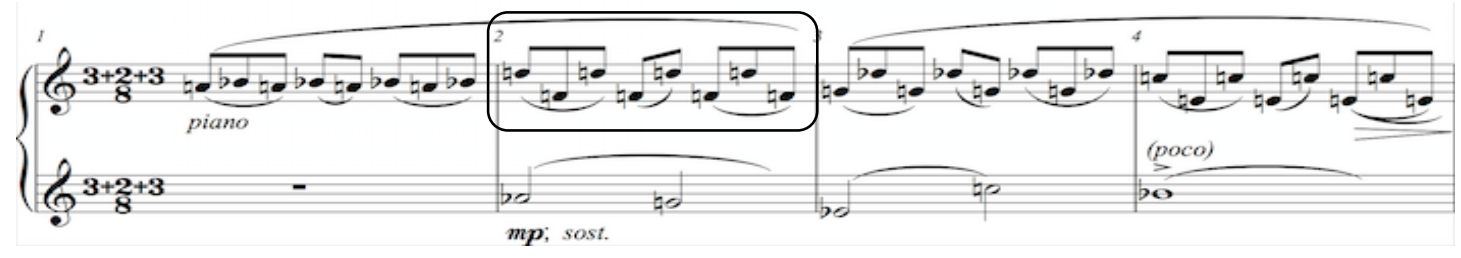

Used by permission.

Copyright by Sugarmusic S.p.A. - Edizioni Suvini Zerboni, Milano (Italy)

Dallapiccola utilizes only two tone rows in this movement. The right hand presents P 11,

whereas the left hand displays I 10. Each row is dodecaphonically independent. D is implied as the tonal center. The B-A-C-H motif here is hidden in the left hand (Eb-E-D flat-D) and is very subtle. $^{55}$

"Linee" is very brief at 10 measures, and uncomplicated considering the slow tempo and sustained pitches. The time signature and rhythmic groupings are quite simple here. The composer incorporates various types of twentieth-century rhythmic writing in this piece. Such examples include mixed rhythm, polyrhythm, polymeter, and irregular rhythm. The piece begins with a polymetric rhythm of $3+2+3 / 8$ in the right hand, simultaneously with $4 / 4$ in the left hand. Dallapiccola concludes the A section by changing time signature to $5 / 8$ in measure five and then

\footnotetext{
${ }^{55}$ Sue Burnett Petito, "The Piano Works of Luigi Dallapiccola (1904-1975): An analysis for performance" (PhD diss., New York University, 1989), 322.
} 
return to the opening in measure six, but this time inverting the lines for the B section. At first glance, these meters may seem complicated, but they actually make the rhythmic groupings clear for the performer. Since the basis is the eighth note and the rhythms are uncomplicated, this piece is quite doable for students.

Most of the dynamics here tend to stay on the soft side. The piece begins with piano for the entire A section. In section $\mathrm{B}$, the tension increases and is therefore marked with $m p$, intense, crescendo, and espressivo. At the end, the dynamic level resolves to piano.

This piece poses little technical or rhythmic challenge for the advanced pianist and is an excellent introduction to Dallapicolla's music. The inversion of the accompanying pattern found in the right hand in the A section to the left hand in the B section requires special attention in order to create a subtle switch of the lines. In addition, as in the other movements, particular control of sound is needed with the emphasis on quiet dynamics. This piece can be categorized as late intermediate.

\section{"Contrapunctus Secondus"}

"Contrapunctus Secondus" (Second Counterpoint) is a contrast in character with the preceding movement. The piece displays pointillistic features as well as a lively, playful character. It is the shortest movement in the whole set at just eight measures and twenty-two seconds. The formal structure of this movement is also a miniature binary form. The A section is from measures 1-4, set apart with a caesura at the end of measure 4; the B section is from measures 5-8.

Dallapiccola utilizes the traditional Baroque compositional technique of canon in this piece. It is a half-beat canon at the interval of a second and also in contrary motion. 
Example 5.5.1 Luigi Dallapiccola Quaderno Musicale di Annalibera: V. "Contrapunctus Secondus" mm.1-2

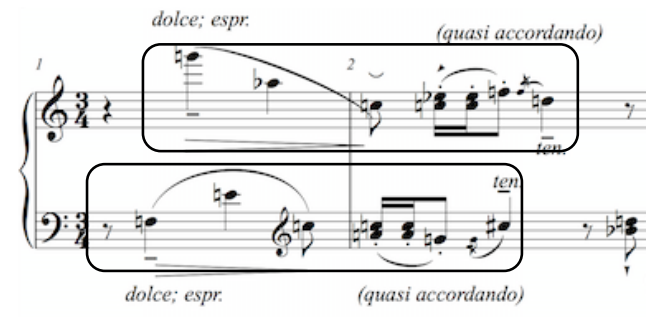

Used by permission.

Copyright by Sugarmusic S.p.A. - Edizioni Suvini Zerboni, Milano (Italy)

There are eight tone rows utilized in "Contrapunctus Secondus." In measures 1-3, the composer uses P 9 in the right hand and I 7 in the left hand. Measures 3-5 have RI 6 and RI 11 written for the right and left hands consecutively. In measures 5-7, the right-hand part contains $\mathrm{P} 0$, and the left-hand part plays I 10. Finally, in measures 7-8, the right hand features R 8 , whereas the left hand features RI $2 .^{56}$ Dallapiccola also incorporates the use of some quasitraditional harmonic progressions here at the end of each phrase (measures 4 and 8 ). There is a V 7 -I 7 cadence implication at the end of the first phrase. The end of the second phrase, from G major 7 to a $\mathrm{C}$ major 7 chord, refers to a V-I progression as well. ${ }^{57}$

The B-A-C-H motif underlines material throughout the entirety of the piece. However, it is not as obvious here as in some of the preceding movements. The accent helps the motif to be more audible. ${ }^{58}$

\footnotetext{
${ }^{56}$ Sue Burnett Petito, “The Piano Works of Luigi Dallapiccola (1904-1975): An analysis for performance" (Ph. D. diss, New York University, 1989), 322.

${ }^{57}$ Ibid., 328.

${ }^{58}$ Ibid., 327
} 
In terms of rhythm, Dallapiccola indicates 3/4 with Poco allegretto; "alla Serenata" here and remain the same throughout the piece. However, non-traditional rhythmic groups and phrasing create syncopation, as do phrases beginning and ending on the anacrusis or across the bar line; thus, it would be helpful for the performer to subdivide into eighth notes while learning this piece. In terms of dynamics, the range again is subtle, from $p p$ to $m f$.

Example 5.5.2 Luigi Dallapiccola Quaderno Musicale di Annalibera: V. "Contrapunctus Secondus" mm. 5-6

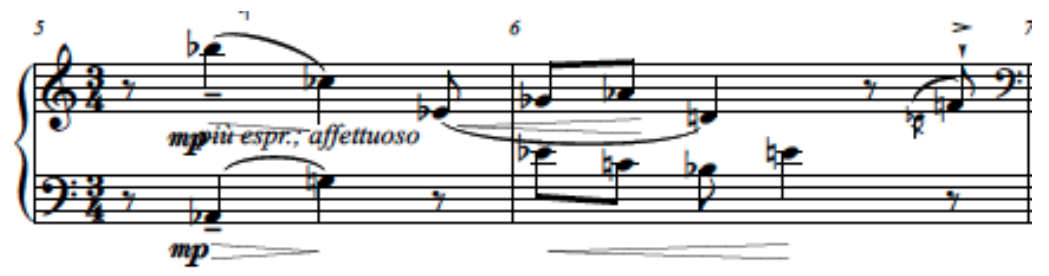

Used by permission.

Copyright by Sugarmusic S.p.A. - Edizioni Suvini Zerboni, Milano (Italy)

This piece stands out among the others as Dallapiccola marks specific Italian terms in every bar throughout the piece, some of which are unusual and require imaginative interpretation: quasi accordando, fuggevole, and scomparendo. Dallapicolla also creates a serenade-like character through several grace notes which give the effect of guitar-like sounds throughout the piece.

\section{"Fregi"}

Similar to Debussy's Arabesque, "Fregi”(Friezes) is also inspired by architecture visual art. This movement is the middle piece of the entire set. Perhaps this is the reason that Dallapiccola named it "Fregi," which is derived from the architectural term frieze, the center of the top part in a building. ${ }^{59}$

\footnotetext{
${ }^{59}$ Petito, op. cit., 330.
} 
Again, like the two previous groups, "Fregi" is paired with "Andantino Amoroso e Contrapuntus Tertius." Dallapiccola marks this movement Molto lento; con espressione parlante (very slow, speaking with expression) as the tempo indication.

The formal structure of "Fregi" is also in binary form. However, the length of each phrase is irregular. Section A is from mm.1-8. Section B is from mm. 8-12. This movement is comprised of six tone rows. The row P 0 is in the right hand from mm. 1-4. Then the left-hand part features I 10 from $\mathrm{mm}$. 3-6, while $\mathrm{R} 7$ enters in $\mathrm{mm}$. 4-8 in the right-hand part. The row I 1 is utilized after I 10 in the left hand in mm. 6-9, with the line then crossing over to the right hand as well. From m. 8 to the end, the right hand is written with pitches from I 4 . However, this row is incomplete. ${ }^{60}$ The last row of this movement enters in the left hand from $\mathrm{m} .9$ until the end. The B-A-C-H motif and its variations are also presented here, but are very subtle and hidden in the melodic line. ${ }^{61}$

Example 5.6.1 Luigi Dallapiccola Quaderno Musicale di Annalibera: VI. "Fregi” mm.1-5

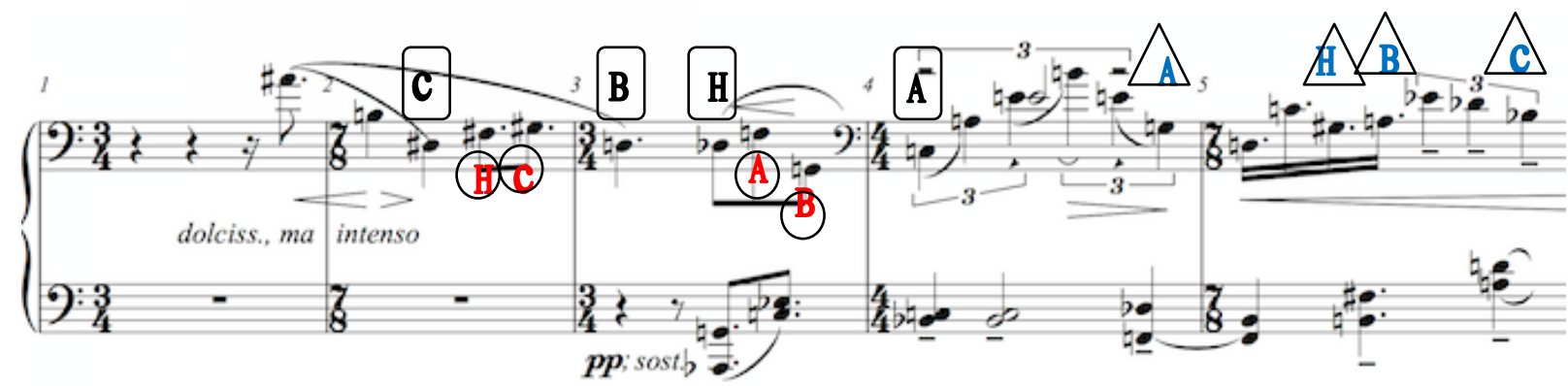

Used by permission.

Copyright by Sugarmusic S.p.A. - Edizioni Suvini Zerboni, Milano (Italy)

\footnotetext{
${ }^{60}$ Petito, op. cit., 322.

${ }^{61}$ Ibid., 333.
} 
There is also a tonal implication here harmonically at both of the cadences. The first place is at the end of the A section in measure 6 where $G$ flat and $F$ are suspended to measure 7 for one and a half bars in the right hand part. This perhaps implies the D tonal center in second inversion. The second place is at the end of the right hand part. $\mathrm{C}$ and $\mathrm{G}$ could be heard to imply the $\mathrm{C}$ major tonality. ${ }^{62}$

Example 5.6.2 Luigi Dallapiccola Quaderno Musicale di Annalibera: VI. "Fregi” measure 7

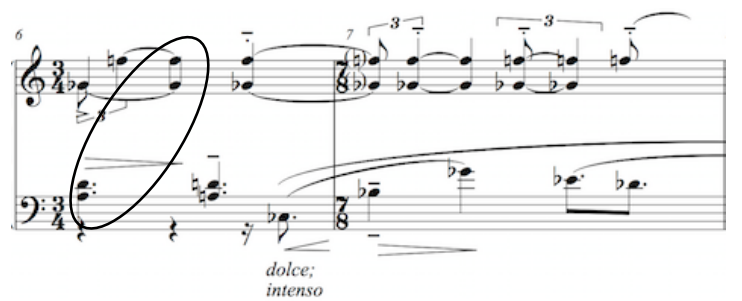

Used by permission.

Copyright by Sugarmusic S.p.A. - Edizioni Suvini Zerboni, Milano (Italy)

Example 5.6.3 Luigi Dallapiccola Quaderno Musicale di Annalibera: VI. "Fregi” measure 8

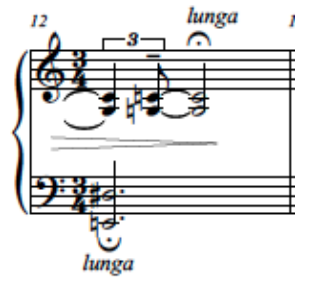

Used by permission.

Copyright by Sugarmusic S.p.A. - Edizioni Suvini Zerboni, Milano (Italy)

In terms of texture, "Fregi" is homophonic with a melody and dyad (two-note) accompaniment, which is alternated in the B section. Each line is dodecaphonically independent as well. It is interesting to note that Dallapiccola notated the entire movement in the bass clef,

${ }^{62}$ Petito, op. cit., 334. 
and it may be noted that later, intentional, the notation of "Contrapunctus Tertius" is all in the treble clef.

The dynamic range is pianissimo throughout the movement with the occasional crescendo and decrescendo. The time signatures in this movement are not complicated, alternating from $3 / 4$ to $7 / 8$, and the slow tempo helps to facilitate realizing the triplet rhythms used throughout. Though it is quite challenging for the performer to keep the tempo very precise, the student should keep in mind the suggestion parlante, which literally means "talking" or "speaking" and which requires good legato even over the large melodic leaps.

One pedagogical issue for this movement is the mood, as students and players will need to project the dark, intense character. The rhythm also requires careful attention with the use of three against two, duplets in 7/8, and dotted notes. Overall this is a late intermediate level work which poses interesting interpretive and technical challenges for the mature student.

\section{“Andantino Amoroso e Contrapunctus Tertius (Canon Cancrizans)"}

"Andantino Amoroso e Contrapunctus Tertius (Canon Cancrizans)" is the third canon of the Quaderno Musical di Annalibera. This time, Dallapicolla uses the cancrizans or "crab" canon. According to Grove Music Online, cancrizans "signifies that a part is to be heard backwards.",63 Paired with "Fregi," the contrasting character of this movement is found immediately in the use of the higher register. Dallapicola marks this movement parlante as in "Fregi," but here adds the Andante Amoroso, which requires a more tender, love-song character.

\footnotetext{
63"Cancrizans." Grove Music Online. Oxford University Press, accessed August 30, 2014, http://www.oxfordmusiconline.com/subscriber/article/grove/music/04723.
} 
Interestingly, Dallapiccola, to make his compositional technique clear for the performer, shows the "crab" canon in red ink at the top of the score. There is a $2^{\text {nd }}$ volta indication as well as a G clef at the end indicating that it should be played backwards the second time. The theme here is presented in dyads, alternating between the hands, which also, perhaps, is reminiscent of the character of a crab walking, or even a conversation between two people, referring to the marking parlante and amoroso.

Example 5.7.1 Luigi Dallapiccola Quaderno Musicale di Annalibera: VII. "Contrapunctus

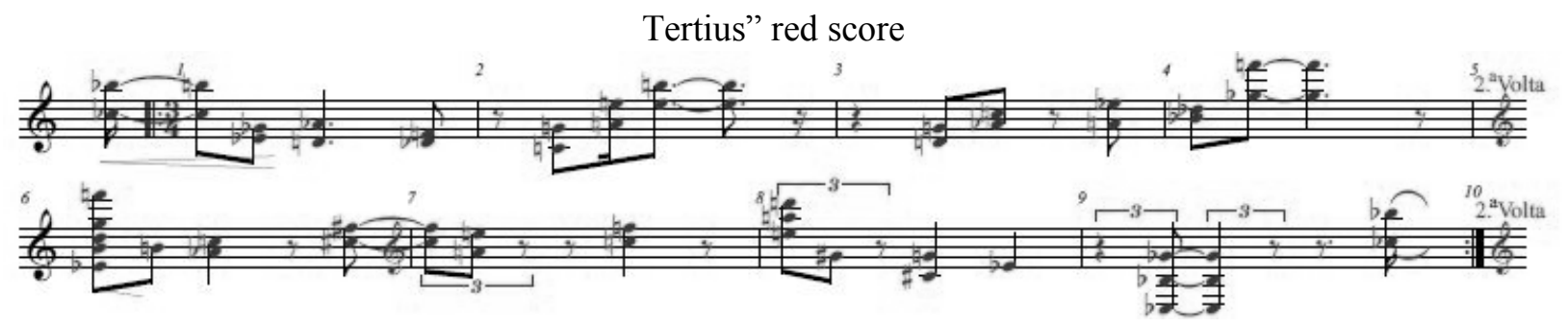

Used by permission.

Copyright by Sugarmusic S.p.A. - Edizioni Suvini Zerboni, Milano (Italy)

The structure here is also in binary form comprised of sixteen bars in total. Each phrase contains four bars. Section A is from mm. 1-8 and section B is from mm. 9-17. The B section is a repetition of the A section with the left hand playing the theme backwards in canon as a second voice. Moreover, both the intervals in the crab-canon as well as the choice of tone row also serve to reference the crab-like character. The intervals in the section that is played backwards is mostly an inversion of the original. The choices of tone rows are an alternation between the original row or inversion and their retrograde rows. Each voice is also dodecaphonically independent. ${ }^{64}$ The B-A-C-H motif here is hidden and hardly audible.

${ }^{64}$ Petito, op. cit., 338 and 372. 
Example 5.7.2 Luigi Dallapiccola Quaderno Musicale di Annalibera:

VII. "Contrapunctus Tertius"

\begin{tabular}{|l|c|c|c|c|c|c|c|c|}
\hline Measures & $1-2$ & $2-4$ & $5-6$ & $7-8$ & $9-10$ & $11-12$ & $13-14$ & $15-17$ \\
\hline Tone Row & P0 & R7 & I5 & RI1 & I1 & RI5 & P7 & R0 \\
\hline Voice & 1 & 1 & 1 & 1 & 2 & 2 & 2 & 2 \\
\hline
\end{tabular}

*Note: in mm. 9-17 voice 1 has the same tone row as in mm. 1-8

Dallapiccola uses 3/4 as the meter here and, like "Fregi," his use of triplet rhythms can be challenging for the student, more so here as the tempo is faster. Control of the sound is also particularly challenging with the dynamics largely piano, and several pianississimo (ppp) along with leggerissimo. Additionally, similar to "Contrapunctus Secondus," Dallapiccola writes several Italian terms as well as articulations that are meant to be followed precisely. The tempo markings here are different between section A and section B where the crab canon enters. Section $\mathrm{B}$ is a little bit slower (quarter note $=52$ ) than section $\mathrm{A}$ (quarter note $=58$ ), which also requires sensitive rhythmic control.

Challenges for the student in this movement include the details of expression which are centered on sound control in the quietest dynamics. The hand crossing that occurs in the B section will also require special attention. However, the most important issue might be a clear illustration of the Andantino Amoroso, depicting the love-song character and sweetly speaking quality. This movement can be categorized as early advanced in level of difficulty. 


\section{"Ritmi"}

"Ritmi" (Rhythms) is the first piece of the last set of Quaderno Musicale di Annalibera before the recapitulation of the whole set with "Quartina." There are three pieces in this final set: "Ritmi," "Colore," and "Ombre." Instead of all movements being binary in their structures, all of them are composed in different forms. "Ritmi" is rondo-like (ABA'B'A'"), whereas "Colore" and "Ombre" are in binary and ternary, respectively. ${ }^{65}$ The character of "Ritmi," as the title infers, is vibrant, energetic, and driving. Moreover, the composer makes full use of the entire keyboard in this exciting movement.

In terms of structure, section $\mathrm{A}$ is from mm. 1-28 and is the longest. Section B is from mm.29- 37 . Then, the next section returns again briefly in $\mathrm{mm} .38-45$ and is followed by B' in mm. 46- 57. Finally, the very brief A'" statement is presented at the end from mm. 58-61 and is only four measures in length. The A and B sections are set up as contrasts to each other in the following ways: the use of opposing dynamics (one is almost entirely loud and one is soft), the use of pointillism, or a disjunct melody in one and contrapuntal writing in the other, and an extremely wide range and homophony in A and a limited range of pitches in B.

\footnotetext{
${ }^{65}$ Petito, op. cit., 332.
} 
Example 5.8.1 Luigi Dallapiccola Quaderno Musicale di Annalibera: VIII. "Ritmi” mm. 1-4

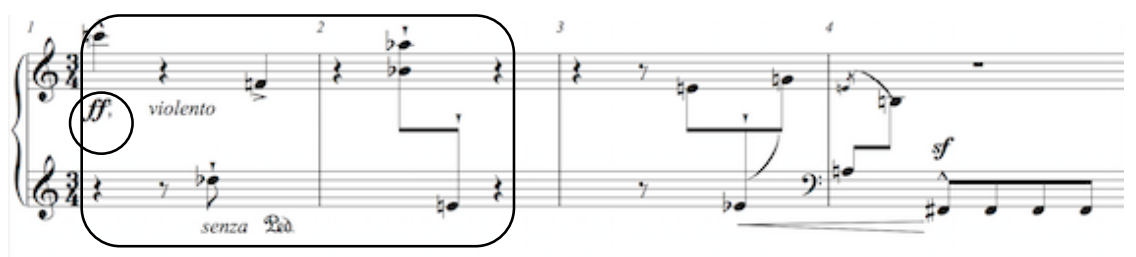

Used by permission.

Copyright by Sugarmusic S.p.A. - Edizioni Suvini Zerboni, Milano (Italy)

Example 5.8.2 Luigi Dallapiccola Quaderno Musicale di Annalibera: VIII. "Ritmi"

mm. $22-25$

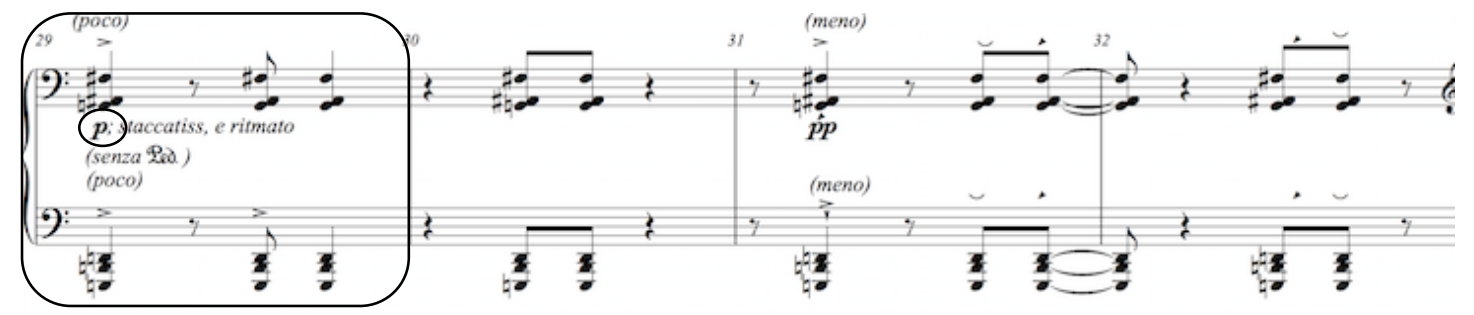

Used by permission.

Copyright by Sugarmusic S.p.A. - Edizioni Suvini Zerboni, Milano (Italy)

The tone row here is presented differently from that in any other piece in Quaderno.

There are approximately 20 combinations of row choices here. ${ }^{66}$ Frequently, they appear in fragmentation (only three or six members out of the12 tones in the row).

The theme of "Ritmi" is one out of, perhaps, five rows in which Dallapiccola make use of every note in the tone row in its entirety. It is located in mm.1-4 with a presence of members from row $\mathrm{P}$ 2. This theme ends with the last note of the row (F sharp) as a pedal point of recurring eighth notes with a sforzando marking. Over that F sharp pedal point, Dallapiccola

${ }^{66}$ Petito, op. cit., 372. 
presents the theme once again in mm. 6-9. However, this time he makes it more interesting by omitting one of the eighth notes and changing the rhythm from 3/4 to the irregular meter of 5/8.

The B-A-C-H motif presented here is very disjunct, so much so that hearing it is challenging. ${ }^{67}$ (See Example 5.8.3)

Example 5.8.3 Luigi Dallapiccola Quaderno Musicale di Annalibera: VIII. "Ritmi" B-A-C-H

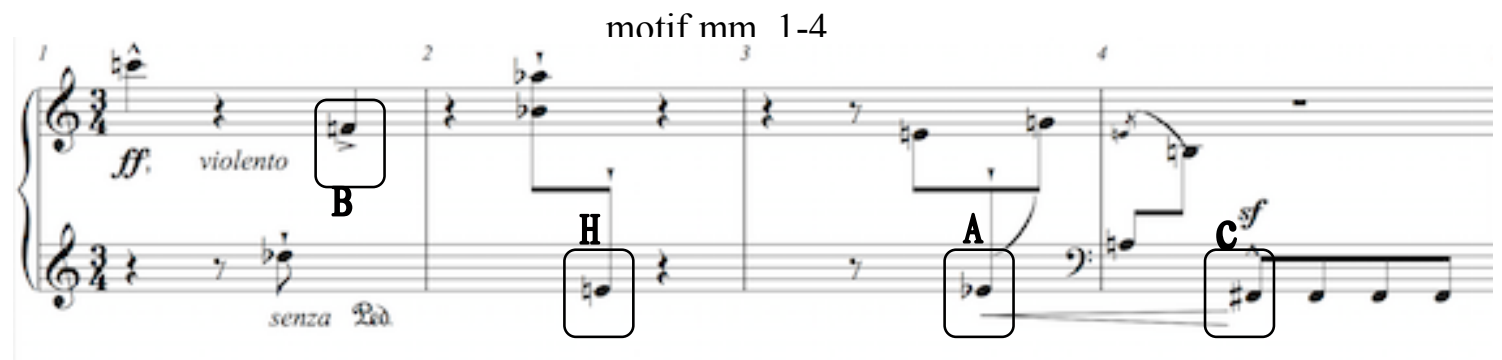

Used by permission.

Copyright by Sugarmusic S.p.A. - Edizioni Suvini Zerboni, Milano (Italy)

Dallapiccola uses a toccata-like style of keyboard writing in this movement. It is the most virtuosic movement of the set. The broad dynamics, articulations with the staccatissimo and accents, repeated-note figures and the fast tempo all contribute to the exciting nature of this piece. (See Example 5.8.4)

Example 5.8.4 Luigi Dallapiccola Quaderno Musicale di Annalibera: VIII. "Ritmi” mm. 29-32

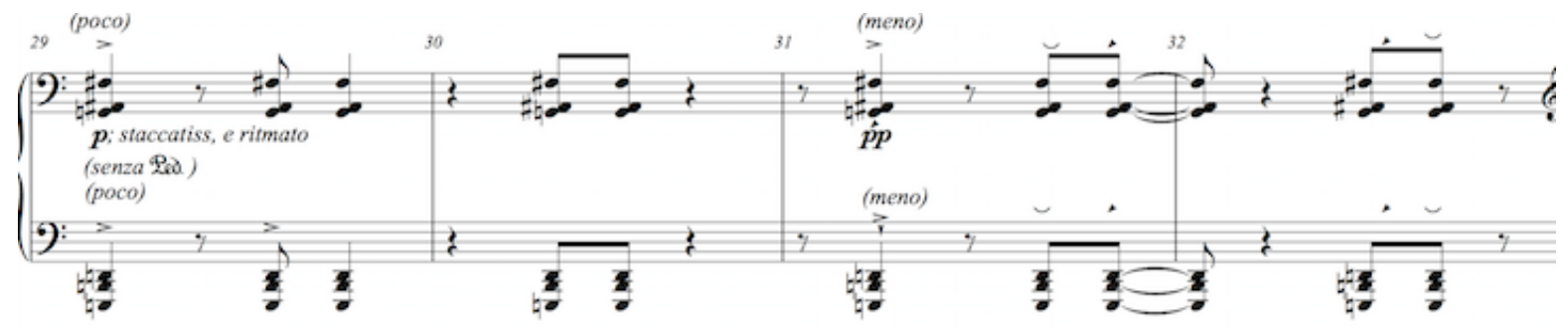

Used by permission.

Copyright by Sugarmusic S.p.A. - Edizioni Suvini Zerboni, Milano (Italy)

${ }^{67}$ Petito, op. cit., 345-346. 
Here again Dallapicolla uses unusual Italian terms in reference to tone quality, including violento (violent), ruvido (rough), and marcatissimo (with very strong accentuation). The rhythmic notation here is also an interesting issue. The composer often manipulates the rhythmic notation by either diminishing or augmenting the time signature of each appearance of the A section motif.

Example 5.8.5 Luigi Dallapiccola Quaderno Musicale di Annalibera: VIII. "Ritmi”" mm. (a) 1, (b) 7, and (c) 45

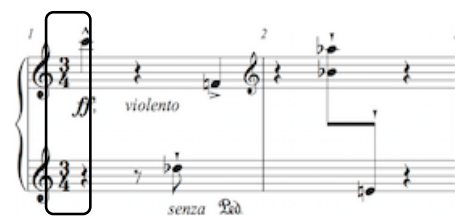

(a)m.1

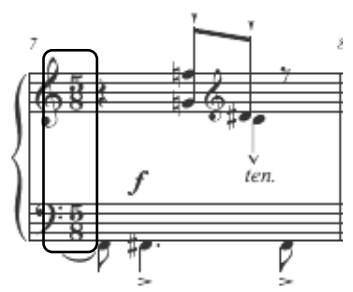

(b) $\mathrm{m} .7$

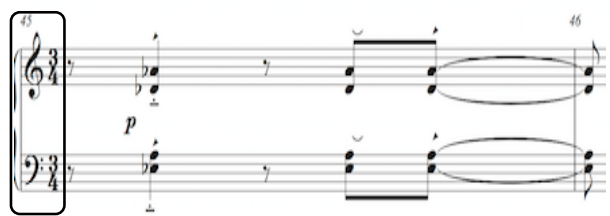

(c) $\mathrm{m} .45$

Used by permission.

Copyright by Sugarmusic S.p.A. - Edizioni Suvini Zerboni, Milano (Italy)

This movement is the most difficult of the Quaderno and requires an advanced technique. As the title suggests, "Ritmi" is an exercise in rapidly changing meters and hand positions, dynamic changes, and a broad range of articulations and use of the keyboard all within a lively Allegro tempo. Teachers could easily treat this not only as a valuable repertoire selection, but also as a highly effective etude for early advanced students. 
"Colore"

"Colore," ("Color") acts as a calm and quiet link among the last three movements. The composer marks this 19-bar work Affettuoso; cullante, and he uses a consistent eighth-note rhythm and moderate tempo to achieve the cullante or "lulling" motion.

Dallapiccola uses binary form with section B being slightly longer (by three measures) than section A. Section A is from mm. 1-8, and section B is from mm. 9-19. Meanwhile, mm.17-19 could be seen as a conclusion of the last five notes from row RI4 in chord form, sustained for two and a half measures.

Dallapiccola also reverts to using a complete row this time. However, measure eight is an exception, as there are only six members from the row of RI 8 present here. The tone-row usage in "Colore" is: 1) P 0: mm. 1-4, 2) R 1: m. 5-7, 3) R I8 (half row): m. 8, 4) I 2: mm. 9-10, 5) I 0: mm. 11-12, and 6) R I4: mm. 13-19. Dallapiccola also makes the B-A-C-H motif very audible here in the melody line. Moreover, the B-A-C-H motif is presented in many forms, including its original motif and its variation. The motifs presented in "Colore" are: 1) mm. 1-4 (F\#, G\#,G,A), 2) mm. 5-8 (F, D, D\#, E), 3) mm. 9-17 (E,D,Eb, Db), 4) D,C,D\#, B), and 5) mm. 13-19 (Eb, F,E, $\mathrm{Gb}){ }^{68}$

The texture in both the A and B sections is homophonic. Section A begins with the melody in the left hand and accompaniment in the right hand. These parts are alternated in section B. The melody and accompaniment parts are not dodecaphonically independent and both hands share the use of the row together. Moreover, both voices are notated in the treble clef, exploring the "color" of the mid and upper registers of the piano.

${ }^{68}$ Petito, op. cit., 356. 
According to Petito, the melody is noted in an arch form ${ }^{69}$ in order to help the B-A-C-H motif sound more intense. The accompaniment here is mostly comprised of an interval of the $7^{\text {th }} .($ See Example 5.9.1)

Example 5.9.1 Luigi Dallapiccola Quaderno Musicale di Annalibera: IX. "Colore” mm. (a) 1 and (b) 9"

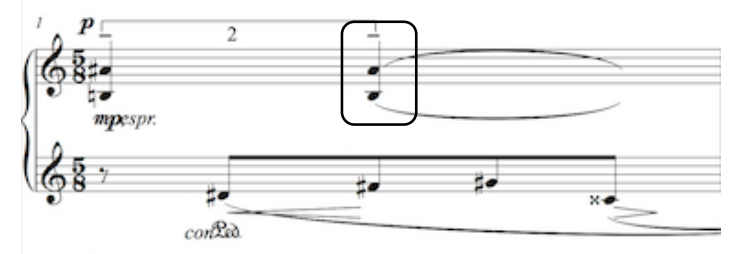

(a): measure 1

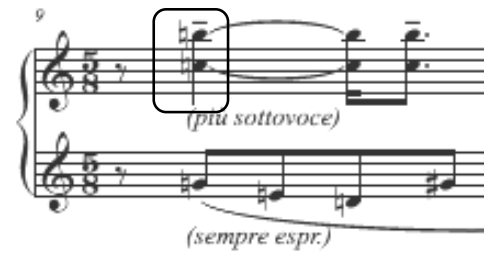

(b): measure 9

Used by permission.

Copyright by Sugarmusic S.p.A. - Edizioni Suvini Zerboni, Milano (Italy)

Dallapiccola uses an eighth-note pulse throughout the movement, which is largely notated in the irregular rhythm of $5 /, 8$ with brief moves to $7 / 8,2 / 8$ and $3 / 8$. Along with the rocking motion of the eighths, Dallapicolla uses duplets; however, as in earlier movements, the slow tempo makes this juxtaposition of rhythms less complicated for the student.

The dynamics utilized here are mostly soft. The piece begins with $m p$ and then becomes softer, all the way down to ppp. As the name infers, color is very important and this is yet

${ }^{69}$ Petito, op. cit., 354. 
another movement where Dallapicolla explores the extreme quiet sounds of the piano. Legato playing and a generous use of the pedal are also necessary here.

The pedagogical and performance issues mainly concern keeping the calm and quiet mood of the piece while articulating the different tone colors. The use of the una corda and damper pedals and employing full and half pedals with both, as well as different articulations (tenuto, portato, and legato) contribute to the challenges of this piece. One other pedagogical challenge is the use of cross rhythms, which is considerably easier than that of the previous piece in Quaderno. This movement can be categorized at the late intermediate level.

\section{"Ombre"}

"Ombre," ("Shadows") is the last piece of this group. It depicts a very grave, sad, and stormy mood and is in contrast to the previous two pieces in mood, character, intensity, and musical texture.

This movement is written in ternary form. The use of fortissimo and accented chords in the low register of the piano in the A section, as well as the alternating tremolo (marked misterioso) in the B section, help to depict the dark character of the piece. Section A is from mm. 1-7, and section B is from mm. 8- 17, with the return of B presented again in mm. 18- 23 . Additionally, according to Petito, Dallapiccola incorporated the "number three concept" throughout the piece. ${ }^{70}$ Such examples are, first, the repetition of the two opening chords for a total of three times. Even more interesting is the fact that Dallapiccola repeated those chords

\footnotetext{
${ }^{70}$ Petito, op. cit., 357.
} 
each time with rhythmic augmentation. The second example could be the pervasive use of triplets throughout the piece, with the third being the fact that the time signature is $3 / 2$.

Example 5.10.1a Luigi Dallapiccola Quaderno Musicale di Annalibera: X. "Ombre"

(a) $\mathrm{mm} \cdot 1-3$

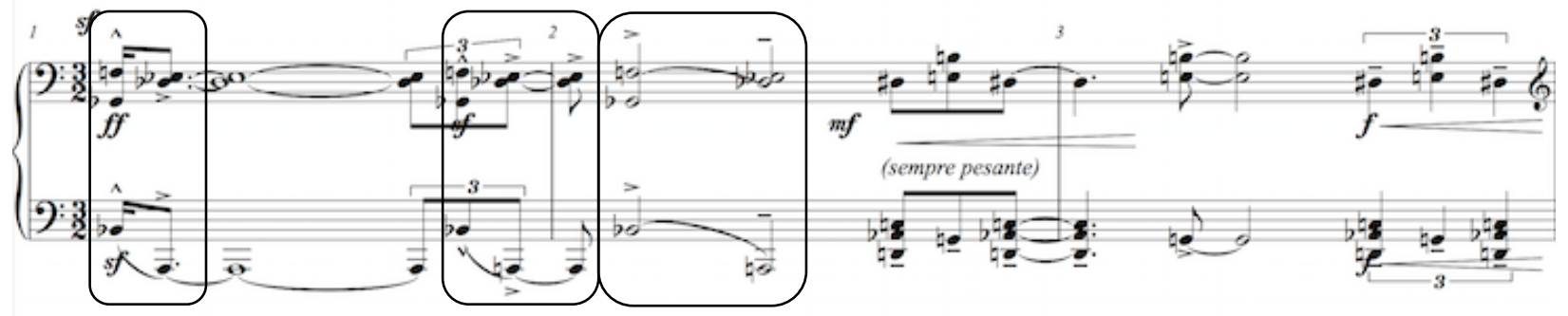

Used by permission.

Copyright by Sugarmusic S.p.A. - Edizioni Suvini Zerboni, Milano (Italy)

Example 5.10.1b Luigi Dallapiccola "Quaderno Musicale di Annalibera: X. Ombre" measure 8

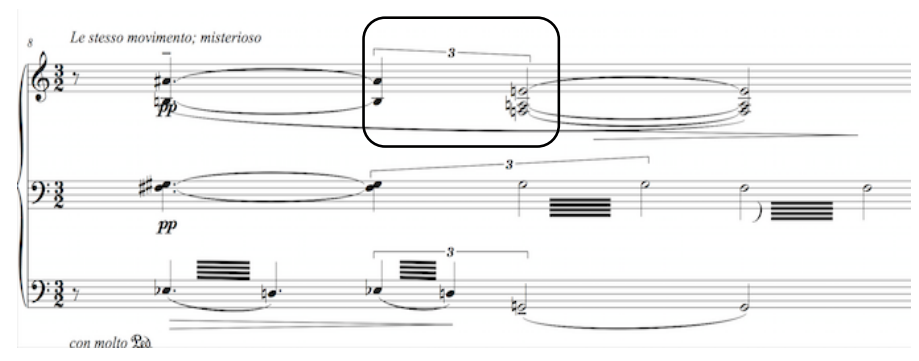

Used by permission.

Copyright by Sugarmusic S.p.A. - Edizioni Suvini Zerboni, Milano (Italy) 
Example 5.10.1c Luigi Dallapiccola "Quaderno Musicale di Annalibera: X. Ombre”

m.1

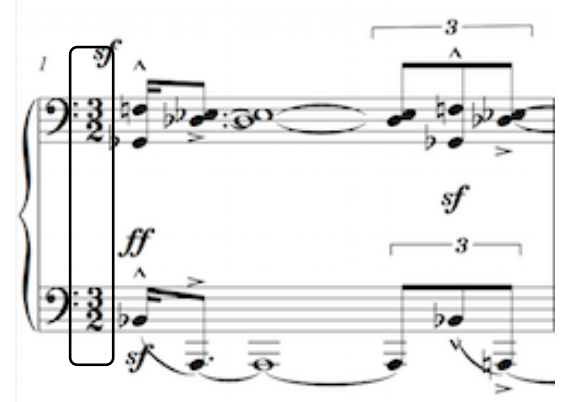

Used by permission.

Copyright by Sugarmusic S.p.A. - Edizioni Suvini Zerboni, Milano (Italy)

Interestingly, the rests in each measure of the B section are augmented from eighth to quarter and then to half rests, again utilizing the rule of three that is present throughout this movement. ${ }^{71}$ (See Example 5.10.2)

Example 5.10.2 Luigi Dallapiccola Quaderno Musicale di Annalibera: X. “Ombre”mm. 8-11

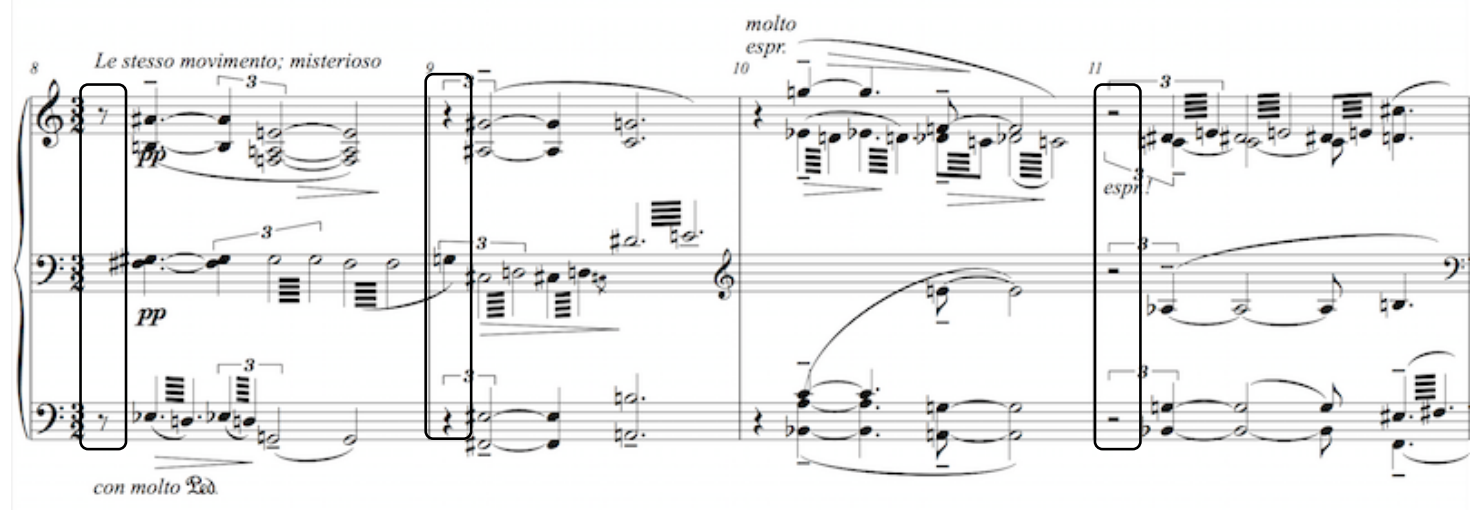

Used by permission.

Copyright by Sugarmusic S.p.A. - Edizioni Suvini Zerboni, Milano (Italy)

${ }^{71}$ Petito, op. cit., 359. 
Though there are many rows utilized here, it is noticeable that Dallapiccola's tone row choice always alternates between the Prime and Inversion rows. The usage of the row in this movement is vertical (a combination of both hands) and does not employ dodechaphonic independence in each line. The rows that Dallapiccola utilizes are: 1) P 7: mm. 1-4, 2) I 7: mm. 5-7 ,P 0: mm. 7-8, I8: m. 9, P 0: m. 10, I 10: mm. 10-12, P 4: m. 13, I 8: m. 14, P 2: m. 15, I 8: mm. 16-17, P 2: mm. 18-20, and I 2: mm. 20-23. ${ }^{72}$

The presence of the B-A-C-H motif here is quite easily audible in comparison to the other movements in Quaderno. Variations of the motif occur simultaneously. ${ }^{73}$ (See examples in Example 5.10.3).

Example 5.10.3 Luigi Dallapiccola Quaderno Musicale di Annalibera: X. "Ombre" B-A-C-H- motif mm.1-3: (a) Gb-F-Ab-G, (b) Db-Eb-D-E, and (c) Bb-A-C-B ”

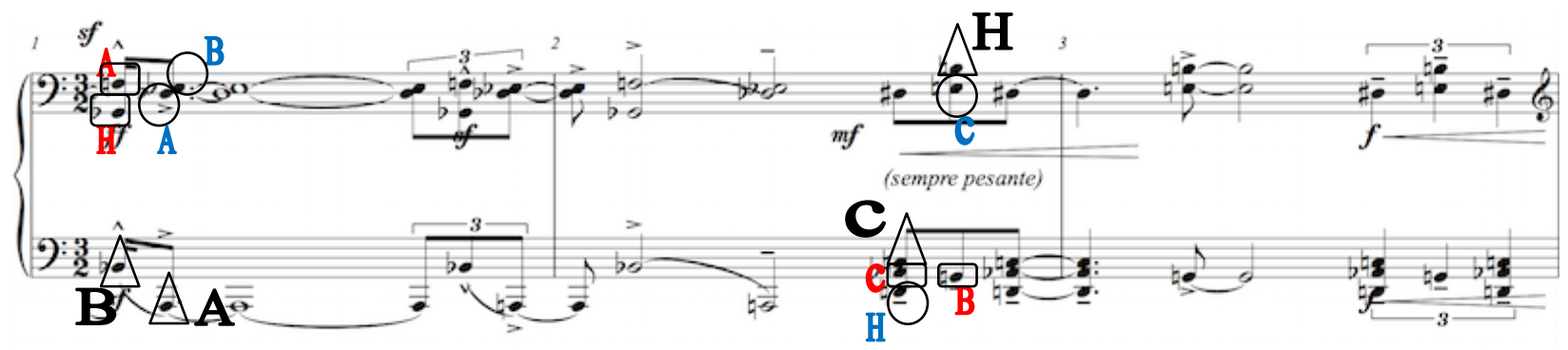

Used by permission.

Copyright by Sugarmusic S.p.A. - Edizioni Suvini Zerboni, Milano (Italy)

\footnotetext{
${ }^{72}$ Petito, op. cit., 372.

${ }^{73}$ Ibid., 358.
} 
Dallapiccola implies the opening theme of "Accenti" in the B section. (See Example 5.10.4a and 4b). However, this time, it is pianissimo.

Example 5.10.4a Luigi Dallapiccola Quaderno Musicale di Annalibera: I. “Accenti”mm.1-4

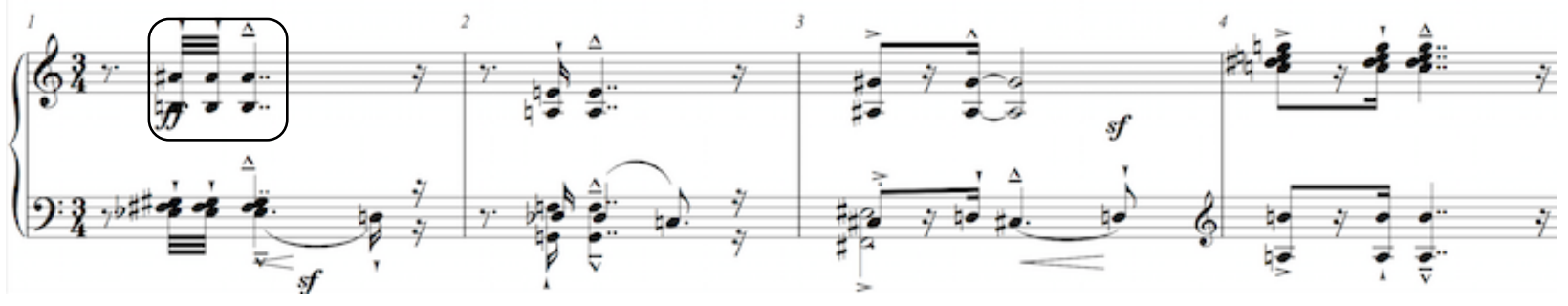

Used by permission.

Copyright by Sugarmusic S.p.A. - Edizioni Suvini Zerboni, Milano (Italy)

Example 5.10.4a Luigi Dallapiccola Quaderno Musicale di Annalibera: X. “Ombre”mm.8-9

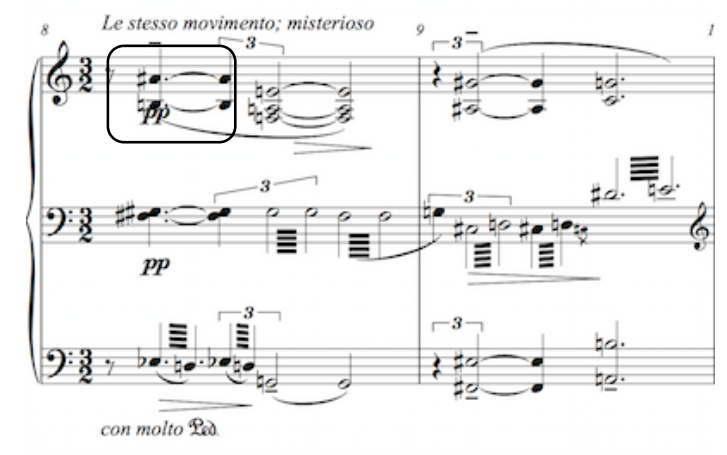

Used by permission.

Copyright by Sugarmusic S.p.A. - Edizioni Suvini Zerboni, Milano (Italy)

Overall, this is a very challenging work, both in the reading and also in the execution. Achieving precise rhythm with the triplets, dotted rhythms and multiple ties combined with meter changes 
and large spans over 3 staves and numerous accidentals make this, along with "Ritmi", one of the most difficult pieces of the Quaderno. This movement is at the early advanced level.

\section{"Quartina"}

Dallapiccola treats Quartina" (“Quatrain”) as a kind of recapitulation or conclusion of the entire Quaderno. This movement is only 18 measures in length, yet it includes references to previous pieces from the set. The structure of this movement, as the title implies, is in four phrases. Each phrase is four bars in length and is written in four voices. In binary form, section A is from mm. 1-8 and section B is from mm. 9-18. Contrasting with "Ombre," Dallapiccola utilizes different rows for the melody and accompaniment. They are dedochaphonically independent. The row choices used in this movement for the melody and accompaniment are as follows: 1) mm. 1-5: I 0 + R 3, 2) mm. 6-9: R 2+R I 8, 3) mm. 10-1 3: R I 8+P 11, and 4) mm. 14-18: P $2+16^{74}$

All variations of the B-A-C-H motif in "Quartina" happen simultaneously as well, similar to the approach used in "Ombre."75 (See Example 5.11.1)

\footnotetext{
${ }^{74}$ Petito, op. cit., 372.

${ }^{75}$ Ibid., 364-5.
} 
Example 5.11.1 Luigi Dallapiccola Quaderno Musicale di Annalibera: XI. “Quartina”

B-A-C-H motif mm.10-13"

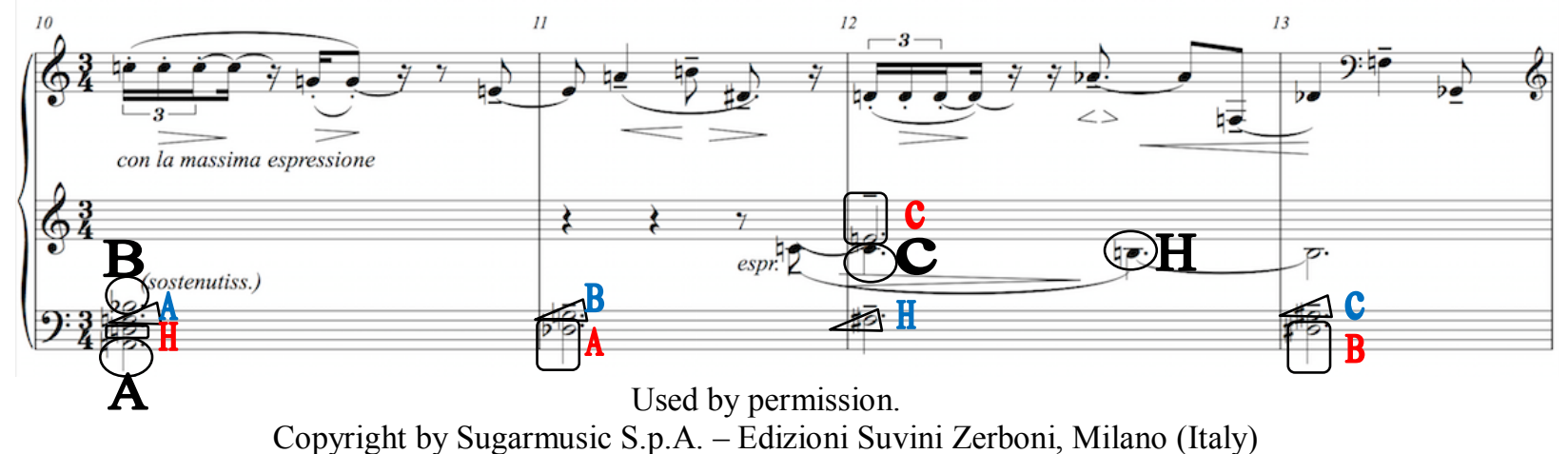

According to Petito, Dallapiccola presents a literal spelling of the B-A-C-H motif at the end of the movement (mm.14-18): H-C-A-B (B, C, A, Bb). Theses pitches are the retrograde version of the B-A-C-H theme. This is used, perhaps, for the purpose of emphasizing the final closure.

Example 5.11.2 Luigi Dallapiccola Quaderno Musicale di Annalibera: XI. "Quartina”

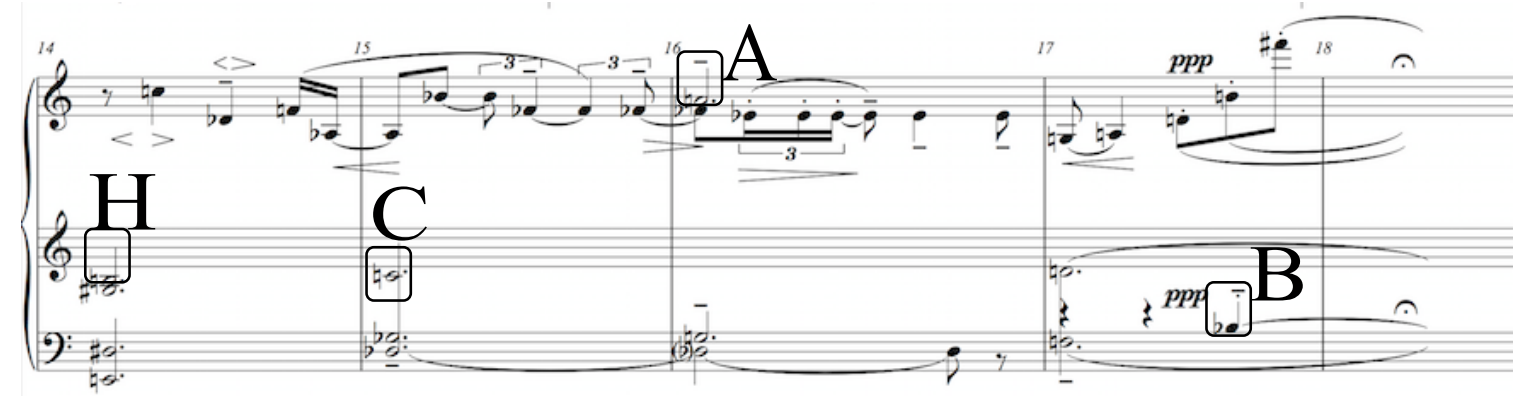

Used by permission.

Copyright by Sugarmusic S.p.A. - Edizioni Suvini Zerboni, Milano (Italy) 
"Quartina" features a lyrical, expressive singing melody in the right hand with an accompaniment of chordal texture in the left-hand part. The middle staff is shared between the melody and accompaniment parts. Even though Dallapiccola notated this movement on three staves, it is very clear to read and not as complicated as the reading of "Contrapunctus Primus." The time signature here is $3 / 4$, with a marking of molto lento; fantastico. The rhythm here is also not complicated and begins with an eighth note upbeat that is tied over to the second bar. The B section is a little bit more active in the melody line as a result of a pervasive use of triplets. (See Example 5.11.3)

Example 5.11.3 Luigi Dallapiccola “Quaderno Musicale di Annalibera:

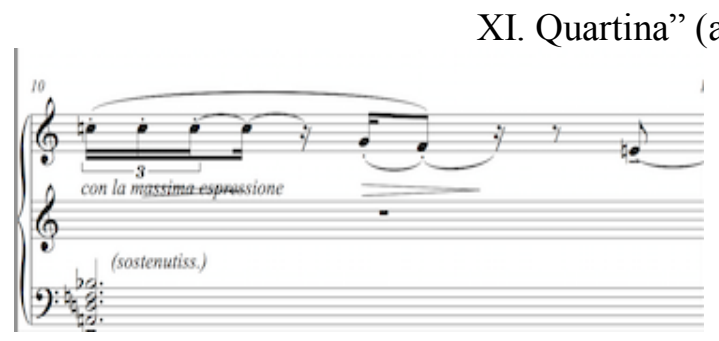

(a) $\mathrm{m} .10$

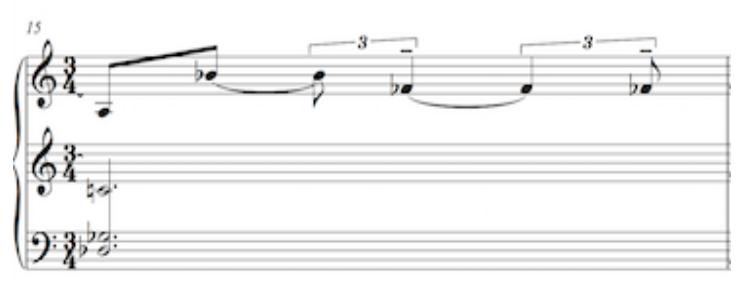

(b) m. 15

Used by permission.

Copyright by Sugarmusic S.p.A. - Edizioni Suvini Zerboni, Milano (Italy)

Articulation is, again, not as complicated as in the previous piece. There are also many tenuto markings. The most noticeable and challenging marking here is, perhaps, a fermata over the last measure to indicate the ending. The character of this last movement is calm, peaceful, and lyrical. Dallapiccola writes this piece within a soft dynamic range, from $p$ to $p p p$, from the beginning to the end. 
The pedagogical issues here include, first, to convince the listener that this is the ending movement of the whole Quaderno. Secondly, it is necessary for the performer to convey a sense of expressiveness through the continuity of the melody and through articulation and rhythmic accuracy in the frame of $p$ to $p p p$ dynamics, which requires control of dynamic shading. Similar to the previous movement, three-staves reading is one more aspect of which to be aware when students first access this piece. Finally, the chordal accompaniment part should not interrupt the flow of the fantasy-like melodic line here. Overall, Quartina could be placed in early advanced difficulty level.

In conclusion, the Quaderno Musicale di Annalibera by Dallapiccola is an effective repertoire choice for teachers to assign to their early advanced students. The Quaderno Musicale di Annalibera is an excellent introduction to twelve-tone music for piano students, as it is accessible and appealing. According to Petito, when Dallapiccola first thought of twelve-tone music, the element of melody initially attracted him, and he believed that the twelve-tone method was a language of many possibilities." ${ }^{, 76}$ The skills piano students will develop from learning this work include gaining important tonal control and mastering complex rhythms between the hands. Even though Dallapiccola indicated that the work should be performed in its entirety, students may take their time in learning one movement after another in a progressive order. Additionally, this work has a high level of correlation with works from the $17^{\text {th }}$ and $18^{\text {th }}$ centuries, which reinforces the connection of this material to more familiar works by Bach and other Baroque composers. It could also serve as an alternative to M. Ravel's Valses nobles et sentimentales.

\footnotetext{
${ }^{76}$ Petito, op. cit., 397.
} 


\section{CHAPTER SIX}

\section{A Child's Exercise Book, Op. 69 by Dmitri Shostakovich (1906-75)}

Dmitri Shostakovich (1906-75), a Russian composer born in St. Petersburg, wrote not only symphonies, but also works in many other genres, including string quartets, concerti, instrumental works, vocal repertoire, and piano works. From a family with a musical background, Shostakovich was a child prodigy. He first began his piano studies with his mother, later studying at a private music school in Glyasser, and was subsequently accepted into the Petrograd Conservatory in 1919.

Shostakovich entered the conservatory as a double major, studying piano with Leonid Nikolayev and composition with Maximilian Steinberg, Nikolai Rimsky-Korsakov's son-inlaw. ${ }^{77}$ The composer lived and worked under the principles of official Soviet policy. ${ }^{78}$ During Stalin's reign, Shostakovich often had to become a camper in his own staircase with his bags packed and ready to leave, as the "secret police" from the government might be looking for him, suspecting him as an insurrectionist. The restrictions that the communist regime at the time imposed on freedom of speech prompted Shostakovich to develop some "secret codes,",79 and he used satire, parody, and grotesque elements throughout his musical language. ${ }^{80}$

\footnotetext{
${ }^{77}$ David Fanning and Laurel Fay, “Shostakovich, Dmitry.” In Grove Music Online (accessed January 25, 2014) http://www.oxfordmusiconline.com/subscriber/article/grove/music/52560pg1?q=shostakovich\&search=quick\&pos= 3\&_start=1\#firsthit//

${ }^{78}$ Stewart Gordon, A History of Keyboard Literature: Music for the Piano and Its Forerunners (Belmont, CA: Schirmer, 1996), 444

${ }^{79}$ Stephen Jackson, back cover of Dmitri Shostakovich: An Essential Guide to His Life and Works (London: Pavillion Books Limited, 1998)

${ }^{80}$ Timothy Joshua Martin, abstract to "The Identification and Interpretation of Irony in Dmitri Shostakovich's Solo Piano Music," (DMA diss., The University of Alabama, 2006), viii.
} 
Shostakovich was influenced by Mahler. They both portray their ideas through the symphonic forms and utilized the code-like language in their musical idioms. The example of Shostakovich's code can be the code of his name "DSCH (D-Eb-C-B)". This code also utilized in his works such as String Quartet No. 8, Symphonies No. 10, and $15 .{ }^{81}$ Shostakovich compositions during the war years often reveal the conflict between his inner unhappy mood versus his role in the outside world. Therefore, Shostakovich's music sometimes contains a hint of a "mock-heroic" character which overcomes the phantom, or the bad character. The second cello concerto and the eighth and fifteenth symphonies are often interpreted as examples that give hints of despair, distantness, and shame. ${ }^{82}$

The quantity of Shostakovich's piano music is quite small in comparison to his output in other genres. His most well-known works for piano include Twenty-Four Preludes and Fugues, Op. 87 (1950-51), Twenty-Four Preludes, Op. 34 (1932-33), two Sonatas, Op. 12 (1926), and Op. 61 (1942), and piano Concerti, Op. 35 (1933) and Op. 102 (1957). Among these piano works are pieces that he dedicated to his children, Galina and Maxim: A Child's Exercise Book, op.69, Concertino for Two Pianos, Op. 94, and Piano Concerto No.2, Op. 102. His piano music is written in a twentieth-century neoclassical style, which features the use of extended composition techniques such as quartal harmony, pandiatonicism, and twelve-tone technique.

Shostakovich had two children with his first wife Nina Varzar: Galina Dmitrievna Shostakovich (b. 1936) and Maxim Shostakovich (b. 1938). During World War II, the children

\footnotetext{
81 "DSCH" In Oxford Music Online (accessed March 5, 2015) http://www.oxfordmusiconline.com.www.libproxy.wvu.edu/subscriber/article/grove/music/25666?q=maxim+shosta kovich\&search=quick\&pos=1\&_start=1\#firsthit

${ }^{82}$ Stephen Jackson, Dmitri Shostakovich: An Essential Guide to His Life and Works (London: Pavillion Books Limited, 1998), 14-15.
} 
were taken care of by Nina's parents at Kuibyshev. Finally, in 1944, the Shostakovich family was reunited in Moscow. ${ }^{83}$ However, Nina passed away suddenly in Armenia on December 4, 1954, requiring Shostakovich to care for his children through this difficult period of their youth by himself. Years later, Galina pursued her degree in Biology at Moscow University, while Maxim studied at the Central Music School and dreamed of becoming a pianist. ${ }^{84}$

Shostakovich wrote three piano pieces for both of his children, Maxim and Galina. $A$ Child's Exercise Book, Op.69 (1944-1945), the first of his teaching exercises, was written for his daughter Galina when she was eight years old and about to carry on the family tradition set by Sofia, Shostakovich's mother, of beginning music study. Later, in 1954, right after he composed the tenth Symphony, Shostakovich wrote Concertino for Two Pianos, Op.94 for his son, followed by his Piano Concerto No. 2, Op. 102 three years later in 1957. Shostakovich wrote both of these pieces to encourage Maxim to pursue a career in music. Maxim performed the Piano Concerto No. 2, Op. 102 for an audition at the Moscow Conservatory and passed the entrance requirement with this performance.

Later at the conservatory, Maxim Shostakovich developed his interest in conducting. He then continued to study conducting with such teachers as Rabinovich, Gauk, Rozhdestvensky, and Markevich. He became an assistant conductor and then principle conductor of the Moscow Philharmonic Orchestra (1963), USSR State Symphony Orchestra (1966), and State Radio

\footnotetext{
${ }^{83}$ Dmitri Sollertinsky, Pages from the life of Dmitri Shostakovich (Harcourt Brace Jovanovich, 1980), 119.

${ }^{84}$ Elizabeth Wilson, Shostakovich: A Life Remembered, (Princeton University Press, 1994), 266.
} 
Symphony Orchestra consecutively. In 1981, Maxim become a political refugee and therefore resided in the USA with his son Dmitry Maximovich Shostakovich who was also a pianist. ${ }^{85}$

A Child's Exercise Book, Op.69, (1944-1945) was written as a birthday present, as well as for pedagogical purposes, for Galina. It was originally comprised of six short pieces, each with a descriptive title: March, Waltz, Sad Tale, Merry Tale, The Bear, and Clockwork Doll. A Child's Exercise Book, Op. 69 was not originally assigned any opus number. Op. 69 was originally assigned for String Quartet No. 2, which has since become Op.68. However, in 1945, Shostakovich added a seventh piece, Birthday, in the set for Galina's ninth birthday (May 30, 1945) and labeled it as Op. $69 .{ }^{86}$ Moreover, this set has several titles after being translated differently from the original Russian, Детская Тетрадь, Ор. 69. Such titles are Children's Pieces, Op.69, A Collection of Children's Pieces, Op.69, and Seven Pieces for Piano, Op.69. However, in this paper A Child's Exercise Book, Op. 69 is utilized following the title in the Novoe sobranie sochineniü (New Collected Works) by Dmitriŭ Dmitrievich by Moskva Publisher. The first piece of the set, March, was premiered by Galina at a public concert of music for children held by the Union of Composers in Moscow. ${ }^{87}$ For the same concert, Shostakovich also followed Galina at the keyboard to present another piece in the set, Waltz. During June 1945, Shostakovich, who was newly hired as an editor-in-chief for a children's radio show about

\footnotetext{
${ }^{85}$ Noël Goodwin, “Shostakovich, Maxim (Maksim).” In Grove Music Online (accessed March 5, 2015) http://www.oxfordmusiconline.com.www.libproxy.wvu.edu/subscriber/article/grove/music/25666?q=maxim+shosta kovich\&search=quick\&pos=1\&_start=1\#firsthit

${ }^{86}$ Allan B. Ho and Dmitry Feofanov, The Shostakovich Wars, 81 (accessed February 25, 2014) http://www.siue.edu/ aho/ShostakovichWars/SW.pdf 81.

${ }^{87}$ Derek C. Hulme, Dmitri Shostakovich Catalogue: The First Hundred Years and Beyond, (Maryland: Scarecrow Press, Inc., 2010) 277.
} 
music, discussed the importance of music in general, as well as this particular set, during his first broadcasts. ${ }^{88}$

A Child's Exercise Book, Op.69, Op.69 is presented in order of progressive difficulty in a two-voice texture with occasional contrapuntal textures, disjunct melodic lines and accidentals. Overall, this set can be categorized as early intermediate with some of the pieces falling under the middle-intermediate level in difficulty. The discussion below illustrates an overall survey of each piece in this set, including analysis (i.e., tonality, structure, dynamics, and tempi) and special pedagogical issues.

\section{"March"}

The set starts with "March", one of the most famous of Shostakovich's A Child's Exercise Book, Op. 69 It is written in the key of C major, at the early intermediate level. "March" features a simple rhythm and melody, but also requires various techniques of piano playing, including sudden changes in dynamics and independence of the hands. This piece is subsequently followed by six more pieces, each gradually increasing in difficulty. ${ }^{89}$

The structure of this work is a simple, short ternary, or ABA', form that is only 24 measures in length. Section A (mm. 1-8) features a trumpet-like march tune in the right hand and a simple, one-note bass line in the intervals of a fourth and fifth (see Example 6.1.1).

88 Laurel E. Fay, Shostakovich: A Life, (New York: Oxford University Press, 2000), 149.

${ }^{89}$ Dmitri Sollertinsky, Pages from the life of Dmitri Shostakovich (Harcourt Brace Jovanovich, 1980), 119. 
Example 6.1.1 Dmitri Shostakovich, A Child's Exercise Book, Op. 69 “I. March" mm. 1-4

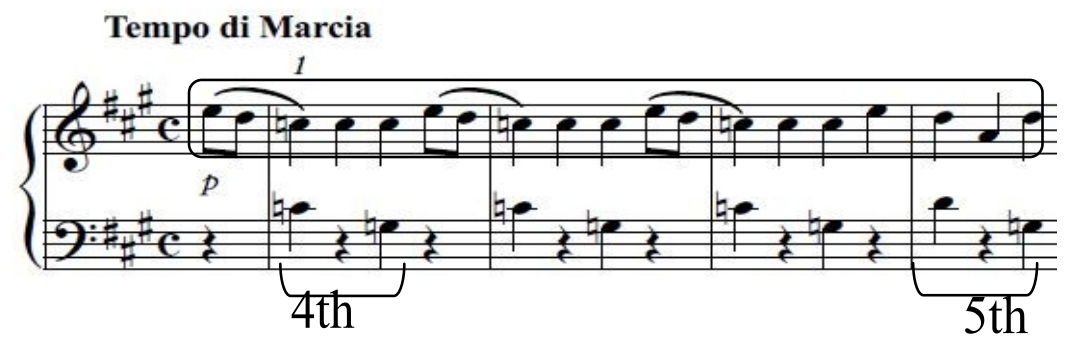

Copyright (C) 1945 (Renewed) by G. Schirmer, Inc. (ASCAP)

International Copyright Secured. All Rights Reserved.

Used by permission of G. Schirmer, Inc. (ASCAP)

In section B (mm. 9-16), a "wrong note" dissonance written in sequences (mm. 9-12, and mm.

13-16) piques the listener's interest (see Example 6.1.2).

Example 6.1.2 Dmitri Shostakovich, A Child's Exercise Book, Op. 69 "I. March" mm. 9-12

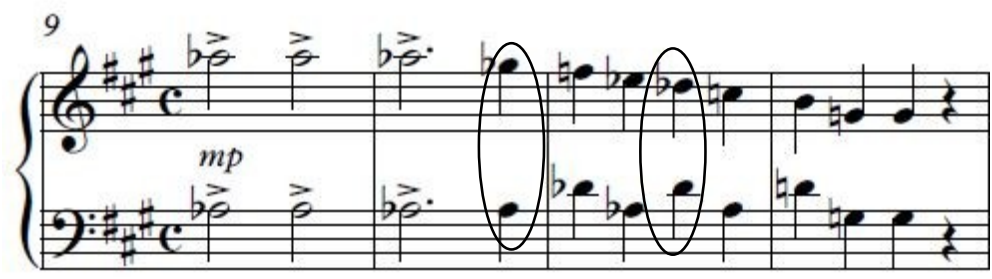

Copyright (C) 1945 (Renewed) by G. Schirmer, Inc. (ASCAP) International Copyright Secured. All Rights Reserved. Used by permission of G. Schirmer, Inc. (ASCAP)

The return of the A section begins at measure17 and lasts until 24. This time, the main theme returns in measure 17 with a little change. The composer incorporates an imitative element beginning first with right hand and then left hand. After that, in the last beat of measure 21 , the left hand takes over the main theme, whereas the right hand changes its role to serve as a countermelody, thus helping students to develop independence of their hands. 
Example 6.1.3 Dmitri Shostakovich, A Child's Exercise Book, Op. 69 “I. March” mm. 18-22

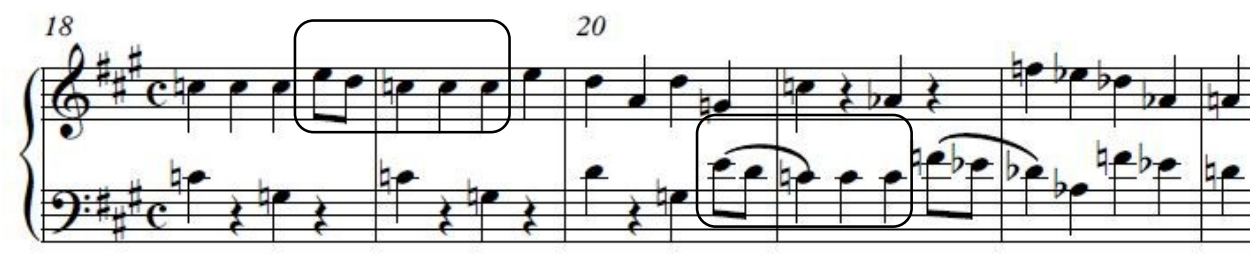

Copyright (C) 1945 (Renewed) by G. Schirmer, Inc. (ASCAP) International Copyright Secured. All Rights Reserved. Used by permission of G. Schirmer, Inc. (ASCAP)

Tempo di Marcia in 4/4 time is marked at the beginning of the piece. However, there is no exact metronome marking. This is a good introductory piece for students to develop rhythmic control and the March style in piano playing. The dynamic range in this movement requires a significant contrast between the loudest and softest moments, which is one of the challenges of this piece. Shostakovich also utilizes accent signs in section B, encouraging students to bring out the new motif, and further develop their ability to execute a range of dynamics.

One of the most fundamental pedagogical concerns in this piece pertains to the fingerings, especially in the last three measures. Several jumps and hand displacements (i.e., from mm. 8-9 and mm. 12-13) also require special attention. The two-voice melody lines in m. 15 and $\mathrm{mm} .20-24$ and the different articulations throughout the piece are also important elements for students to develop. Attention to these details enables the performer to illustrate accurately the intended character of the piece. 


\section{"Waltz"}

"Waltz,", the second movement of the set, was written after Galina had finished learning and performing "March," which took her some months. "Waltz" is written in the key of A minor at the early intermediate level, with the melody in the right hand and a simplified waltzstyle accompaniment in the left hand.

The formal structure of "Waltz" is a simple binary form, with the A section lasting from mm. 1-17, and the B section lasting from mm. 17-33. The right hand melody with the left hand accompaniment is presented in canonic rhythm, with the left hand one bar behind, in a kind of question and answer structure (See Example 6.2.1).

Example 6.2.1 Dmitri Shostakovich, A Child’s Exercise Book, Op. 69 “II. Waltz" mm.1-4

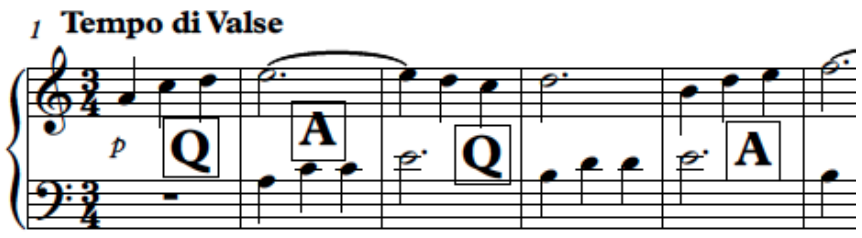

Copyright (C) 1945 (Renewed) by G. Schirmer, Inc. (ASCAP) International Copyright Secured. All Rights Reserved. Used by permission of G. Schirmer, Inc. (ASCAP)

An imitation in a similar rhythmic pattern also appears in the B section (mm. 17-33), however, this time with $\mathrm{Eb}$ as the tonal center. The dynamic range in this piece is not very large in comparison to "March," the first movement of the set. However, the crescendo and diminuendo signs are marked in the music, which will help students develop these gradual changes in dynamics.

\footnotetext{
${ }^{90}$ Laurel E. Fay, Shostakovich: A Life, (New York: Oxford University Press, 2000), 149.
} 
This movement can also be considered a good introductory piece, in this case for playing and projecting the rhythm in the waltz style. It can be a challenge for students to feel the waltz rhythm in one pulse per bar. Another challenge in this piece is shaping the melodic line in the right hand. Teachers and students should be aware of not accenting the second beat after the tie as it would disrupt the shape of the phrase (See Example 6.2.2) Moreover, teachers should also be aware of the fingering issues for achieving legato as the range of the melody and the spacing of the notes make it difficult for students with small hands to play this movement (see Example 6.2.3).

Example 6.2.2 Dmitri Shostakovich, A Child's Exercise Book, Op. 69 "II. Waltz" mm. 1-4

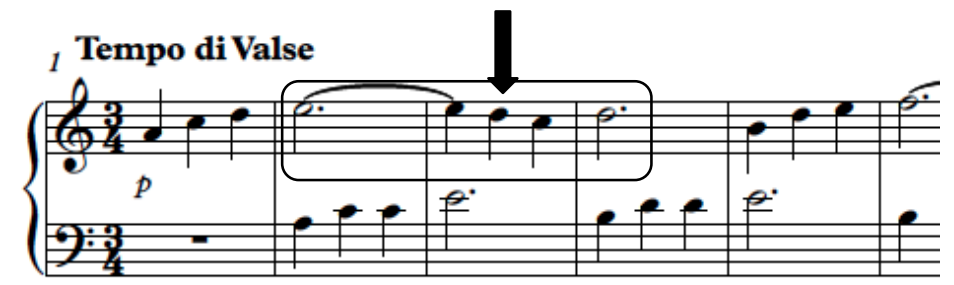

Copyright (C) 1945 (Renewed) by G. Schirmer, Inc. (ASCAP) International Copyright Secured. All Rights Reserved. Used by permission of G. Schirmer, Inc. (ASCAP)

Example 6.2.3 Dmitri Shostakovich, A Child's Exercise Book, Op. 69 "II. Waltz" mm. 9-10

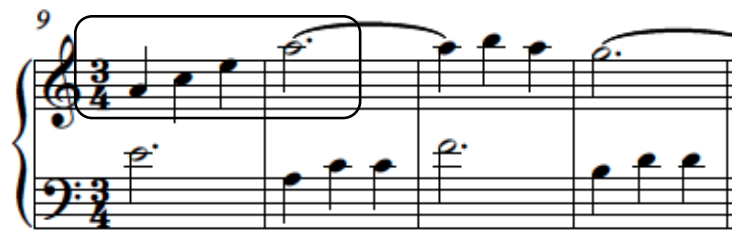

Copyright (C) 1945 (Renewed) by G. Schirmer, Inc. (ASCAP) International Copyright Secured. All Rights Reserved. Used by permission of G. Schirmer, Inc. (ASCAP) 


\section{"The Bear"}

"The Bear" is in the key of D major and at the middle intermediate level. Here Shostakovich depicts the image of a bear by starting the piece with a two-voice texture an octave apart, sounding somewhat like a "walking bear" motif (see Example 6.3.1). The movement becomes more complicated through the use of occasional four-voice writing.

This movement is comprised of three parts and could be identified as A B Coda: A (mm.1-16), B (mm.17-32), and Coda (mm. 33-48). The piece begins with an antecedent-andconsequent phrase (mm. 1-8) starting with the "walking bear" theme (mm. 1-4). The antecedent phrase of the "walking bear" motif is presented in open fourths and octaves (see Example 6.3.1).

Example 6.3.1 Dmitri Shostakovich, A Child's Exercise Book, Op. 69 "III. The Bear" mm.1-4

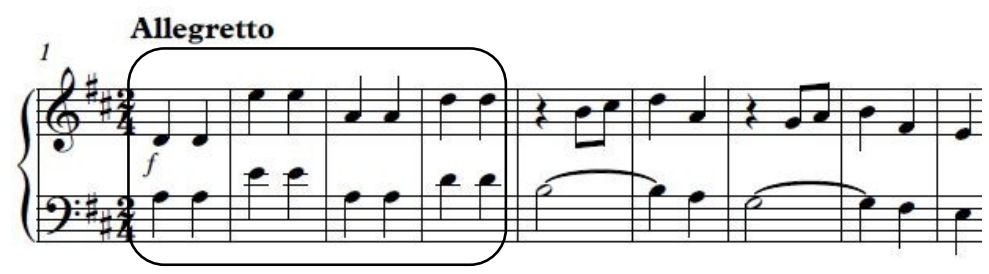

Copyright (C) 1945 (Renewed) by G. Schirmer, Inc. (ASCAP) This arrangement copyright $(\mathcal{C} 1986$ by Edwin F. Kalmus \& Co., Inc. All Rights Reserved.

Then, in measures 5-8, the vertical "walking bear" tune is transformed into the lyrical consequent phrase. (See Example 6.3.2) 
Example 6.3.2 Dmitri Shostakovich, A Child's Exercise Book, Op. 69 “III. The Bear” mm.5-8

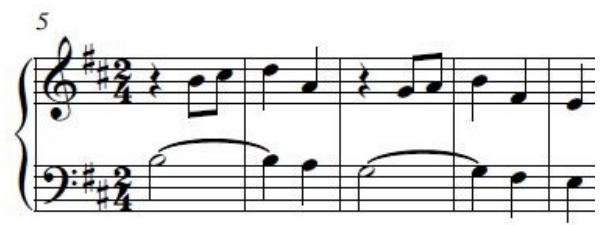

Copyright (C) 1945 (Renewed) by G. Schirmer, Inc. (ASCAP) This arrangement copyright (C) 1986 by Edwin F. Kalmus \& Co., Inc.

All Rights Reserved.

An inversion of the "walking bear" motif in section A is presented in section B, the next part of the piece (see Example 6.3.3).

Example 6.3.3 Dmitri Shostakovich, A Child's Exercise Book, Op. 69 "III. The Bear" mm. 17-23

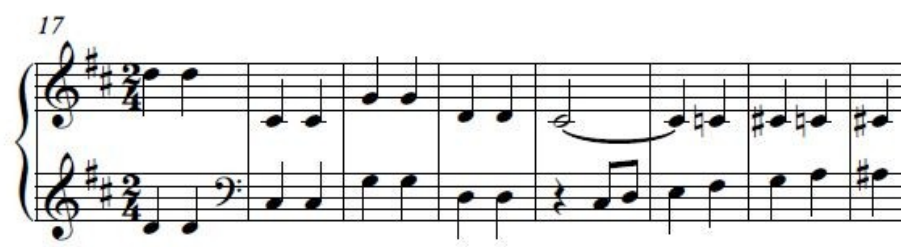

Copyright (C) 1945 (Renewed) by G. Schirmer, Inc. (ASCAP) This arrangement copyright (C) 1986 by Edwin F. Kalmus \& Co., Inc. All Rights Reserved.

The end of the B section comes in measure 32, where the composer has written a quasiending cadence that concludes the section in the key of D major. However, the piece continues with the coda, featuring a new motif in four parts with a piano marking, followed by the "walking bear" motifs. Those motifs are repeated again in the last eight bars, but the second time are specifically stated an octave lower. The tempo of this movement is marked Allegretto in 2/4 time and has a larger dynamic contrast (between piano and forte) in comparison with the prior movement.

There are two main issues to be aware of in terms of pedagogical concerns. The first issue is the disjunct sounds that utilize a wide range of keyboard. Students need to be careful when navigating those jumps. The second involves the familiarity of those disjunct and dissonant 
sounds. It would be helpful for teachers to provide the students with a recording of this particular movement to help them become familiar with Shostakovich's interesting musical language.

\section{"A Happy Fairy Tale"}

The fourth piece in the set, "A Happy Fairy Tale" is again in D major and at the middle intermediate level. This movement has more than one title resulting from different translations as well and is sometimes called "A Funny Story" It is also in a two-voice texture and is comprised of more technically demanding passages than the previous movements in this set.

The form of this movement is ternary (ABA'). Each section is asymmetrical in terms of length. Section A (mm. 1-16) features a conversational, two-voice style with the theme in the right hand being comprised of triads in a descending sequence (mm. 1-4) (see Example 6.4.1).

Example 6.4.1 Dmitri Shostakovich, A Child's Exercise Book, Op. 69, "IV. Happy Fairy Tale" mm. 1-4

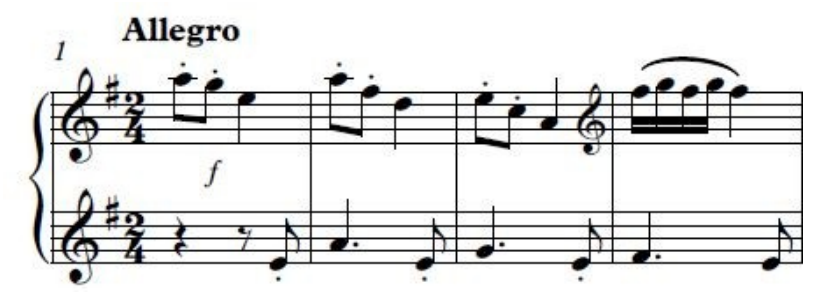

Copyright C 1945 (Renewed) by G. Schirmer, Inc. (ASCAP) International Copyright Secured. All Rights Reserved. Reprinted by Permission.

This is then followed by triads in an ascending sequence in $\mathrm{mm}$. 5-8, with a trill-like ending in both mm. 4 and 8 (see Example 6.4.2). 
Example 6.4.2 Dmitri Shostakovich, A Child's Exercise Book, Op. 69, "IV. Happy Fairy Tale" mm.5-8

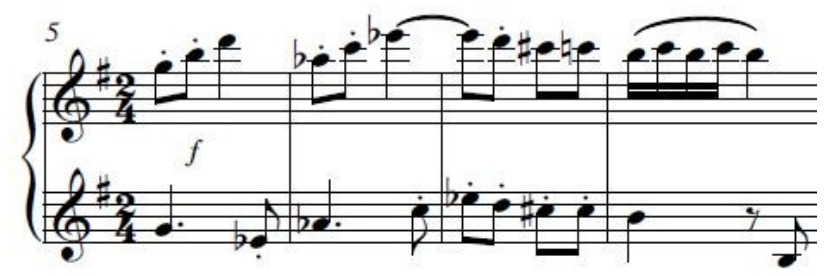

Copyright $\mathbb{C} 1945$ (Renewed) by G. Schirmer, Inc. (ASCAP) International Copyright Secured. All Rights Reserved. Reprinted by Permission.

The main theme comes back once again in measure 9 and leads to the temporary tonal center of $\mathrm{E}$ at the end. Section B (mm. 17-32) has A major as its tonal center and has the character of a chasing game, with the right hand playing a syncopated rhythm that complements the left hand part (see Example 6.4.3).

Example 6.4.3 Dmitri Shostakovich, A Child's Exercise Book, Op. 69, "IV. Happy Fairy Tale” mm. 17-21

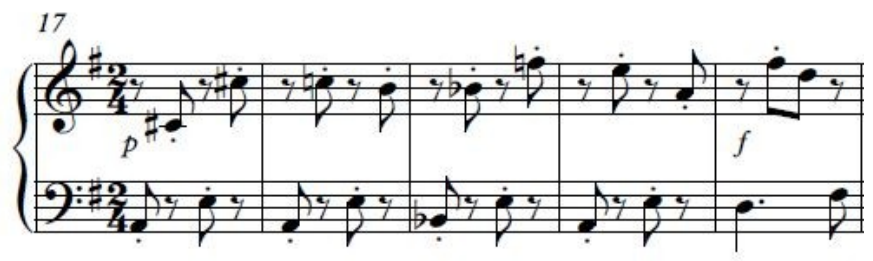

Copyright $($ C 1945 (Renewed) by G. Schirmer, Inc. (ASCAP) International Copyright Secured. All Rights Reserved. Reprinted by Permission.

There is a new pattern containing sixteenth notes in measure 29 , toward the end of the piece, that ushers in the arrival of $\mathrm{A}^{\prime}$ (see Example 6.4.4). 
Example 6.4.4 Dmitri Shostakovich, A Child's Exercise Book, Op. 69, IV. "A Happy Fairy Tale" mm. 29-31

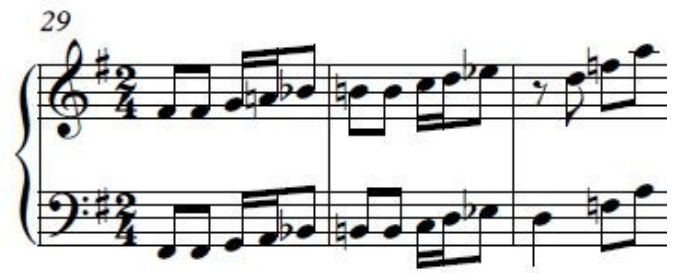

Copyright (C) 1945 (Renewed) by G. Schirmer, Inc. (ASCAP) International Copyright Secured. All Rights Reserved. Reprinted by Permission.

Finally, section A' (mm. 33-40), brings back a fragment of the motifs from both the A and B sections in mm. 33-36 and then in m. 37, subsequently. However, this time the return of $\mathrm{A}$ is presented with the melody in the left hand instead of the right hand (see Example 6.4.5a and $5 b)$.

Example 6.4.5a Dmitri Shostakovich, A Child’s Exercise Book, Op. 69, "IV. Happy Fairy Tale" mm. 33-35

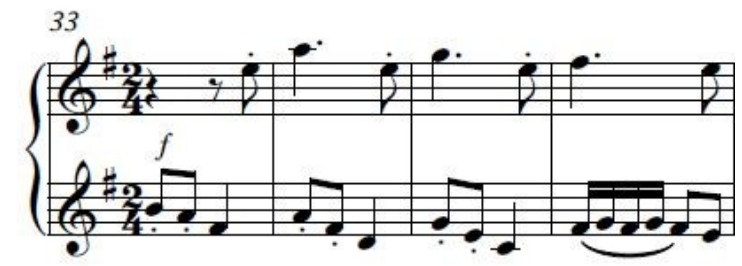

Copyright (C) 1945 (Renewed) by G. Schirmer, Inc. (ASCAP) International Copyright Secured. All Rights Reserved. Reprinted by Permission. 
Example 6.4.5b Dmitri Shostakovich A Child's Exercise Book, Op. 69, "IV. Happy Fairy Tale” m. 37

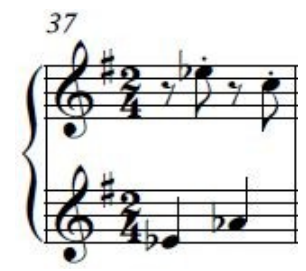

Copyright (C) 1945 (Renewed) by G. Schirmer, Inc. (ASCAP) International Copyright Secured. All Rights Reserved. Reprinted by Permission.

In addition, some of the rhythmic figurations between the two voices which complement each other also resemble the composer's mature compositional style. Such examples could be seen in his Concertino for Two Pianos, Op. 94 and Piano Concerto No. 1, Op.35, (fourth movement) (see Example 6.4.6a and $\mathrm{b}$ and 6.4.7a and $\mathrm{b}$ ).

Example 6.4.6a Dmitri Shostakovich, A Child's Exercise Book, Op. 69, "IV. Happy Fairy Tale" measure (a) 4 and (b) 22

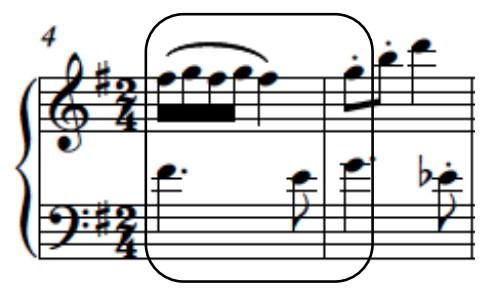

(a)

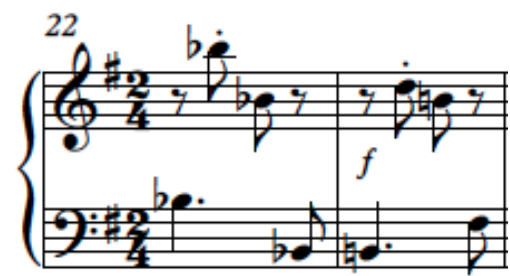

(b)

Copyright (C) 1945 (Renewed) by G. Schirmer, Inc. (ASCAP) International Copyright Secured. All Rights Reserved. Reprinted by Permission. 
Example 6.4.6b Dmitri Shostakovich, Concertino for Two Pianos, Op. 94, mm. 59-60, and Piano

Concerto No. 1, Op.35, (fourth movement) measure 469

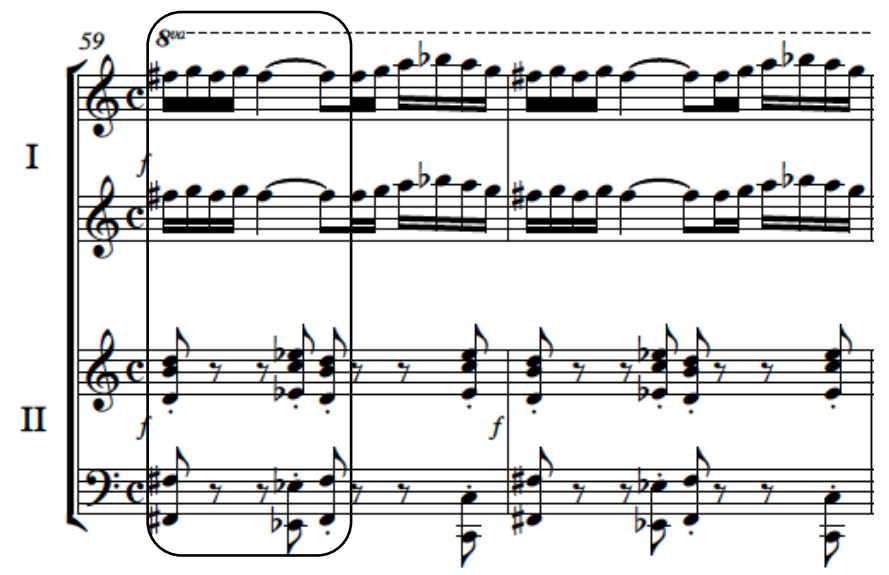

Copyright (C) 1955 (Renewed) by G. Schirmer, Inc. (ASCAP) International Copyright Secured. All Rights Reserved. Used by Permission.

(a)

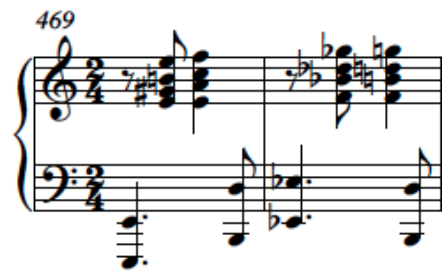

Copyright (C) 1934 (Renewed) by G. Schirmer, Inc. (ASCAP) International Copyright Secured. All Rights Reserved.

Used by Permission.

Warning: Unauthorized reproduction of this publication is prohibited by Federal Law and is subject to criminal prosecution

(b)

With its many accidentals, "A Happy Fairy Tale" is a good piece for middle intermediate students to develop their reading abilities. The triad patterns and hand displacements which create disjunct sounds spanning a wide range of the keyboard are other challenging issues in this movement. Further, it is essential that teachers help students find effective fingerings based on 
the musical patterns. Lastly, developing the crisp articulations in this piece is also important to help the students depict the "cheerful" character of "A Happy Fairy Tale."

\section{"Sad Fairy Tale"}

"Sad Fairy Tale" is written in the key of G major. This piece provides an effective example illustrating that minor keys are not always related to the "sad" emotion. In this case, Shostakovich has chosen an adagio tempo in 2/4 time, as well as legato markings and gradual changes in dynamics to help convey the sad mood.

This movement is written in a two-voice texture, its mood contrasting with that of the prior movement. Ternary (ABA') form is the structure of “A Sad Fairy Tale." Section A (mm. 116) begins with three and a half measures of introduction in the left hand. The first eight measures are reminiscent of a promenade-like theme. This walking character contributes to the sad nature of this piece and uses a rhythm that permeates this entire movement (see Example $6.5 .1)$

Example 6.5.1 Dmitri Shostakovich A Child's Exercise Book, Op. 69, "V. Sad Fairy Tale" mm. 1-8

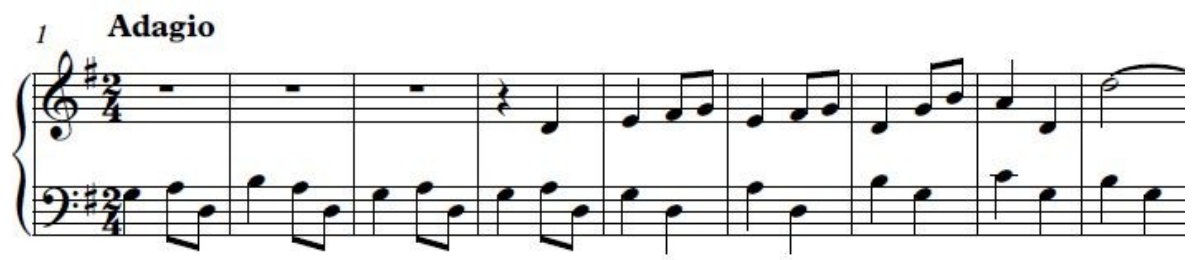

Copyright (C) 1945 (Renewed) G. Schirmer, Inc. (ASCAP) International Copyright Secured. All Rights Reserved. Used by permission of G. Schirmer, Inc. (ASCAP)

Section B (mm. 17-36) begins with a promenade-like theme in the left hand, which is similar to section A. Then, a very short interlude of conversational themes between the left and right hand 
follows in measure 25 before the composer brings back the material from section $\mathrm{A}$ in measure 37 (see Example 6.5.2).

Example 6.5.2 Dmitri Shostakovich A Child's Exercise Book, Op. 69, "V. Sad Fairy Tale" mm. 25-29

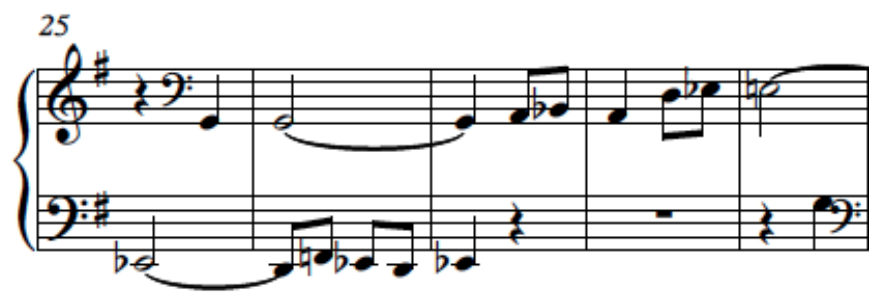

Copyright (C) 1945 (Renewed) G. Schirmer, Inc. (ASCAP) International Copyright Secured. All Rights Reserved. Used by permission of G. Schirmer, Inc. (ASCAP)

The material from section A returns with the start of A', beginning in measure 37 and lasting through measure 60 , where the material from the introduction appears once again.

One pedagogical concern in this movement involves the expressive mood of the piece in the Adagio tempo. Students need to be able to play lyrically and with legato in order to convey the "sadness." A non-traditional harmonic progression, along with the presence of accidentals and a wide use of the keyboard's range, require very accurate and careful notereading when students begin to learn the piece, as their ears may take a while to adjust to the "wrong notes" and dissonant sounds. This piece is at the middle intermediate level.

\section{"The Mechanical Doll"}

"The Mechanical Doll", written in the key of B minor. This movement also has more than one title resulting from different translations and is sometimes called "Clockwork Doll." It is in the style of F. Burgmüller's famous “Arabesque” from 25 Études faciles et progressives, Op. 100. However, this movement is more difficult. It requires a moderately fast tempo and clean articulation to depict the "mechanical doll" character (see Example 6.6.1). 
Example 6.6.1 Dmitri Shostakovich, A Child's Exercise Book, Op. 69, "VI. Mechanical Doll” mm. 1-8
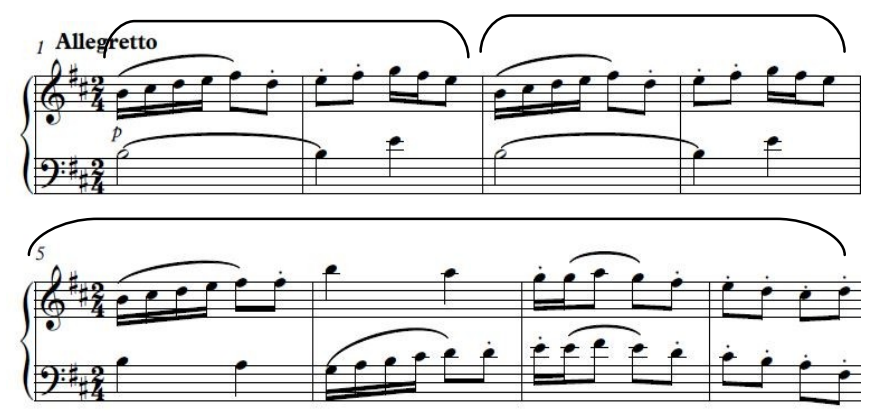

Copyright (C) 1945 (Renewed) G. Schirmer, Inc. (ASCAP) International Copyright Secured. All Rights Reserved. Used by permission of G. Schirmer, Inc. (ASCAP)

The opening rhythmic figurations in this movement are also similar to motives in

Shostakovich's bigger works such as the Piano Concerto No. 1, Op. 35 as well as the Concertino for Two Pianos, Op. 94.

Example 6.6.2a Dmitri Shostakovich A Child's Exercise Book, Op. 69, "VI. Mechanical Doll” mm. 1-2

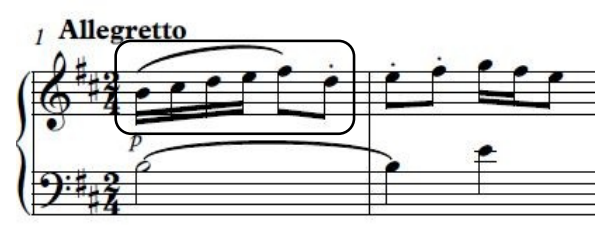

Copyright (C) 1945 (Renewed) G. Schirmer, Inc. (ASCAP) International Copyright Secured. All Rights Reserved. Used by permission of G. Schirmer, Inc. (ASCAP) 
Example 6.6.2b Dmitri Shostakovich Concertino for Two Pianos, Op. 94, measure 125, and Piano Concerto No. 1, Op.35, $4^{\text {th }}$ mvt. measure 326

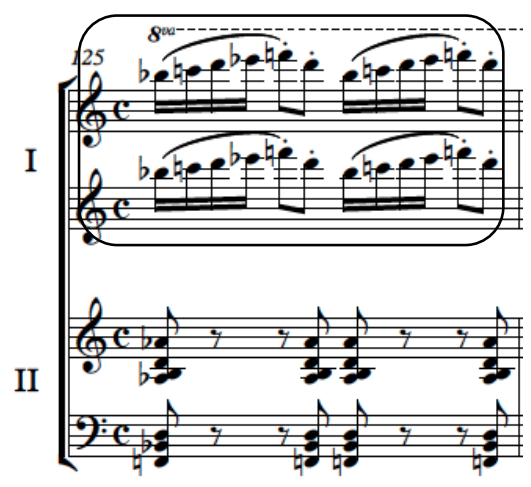

Copyright (C) 1955 (Renewed) by G. Schirmer, Inc. (ASCAP) International Copyright Secured. All Rights Reserved. Used by Permission.

(a)

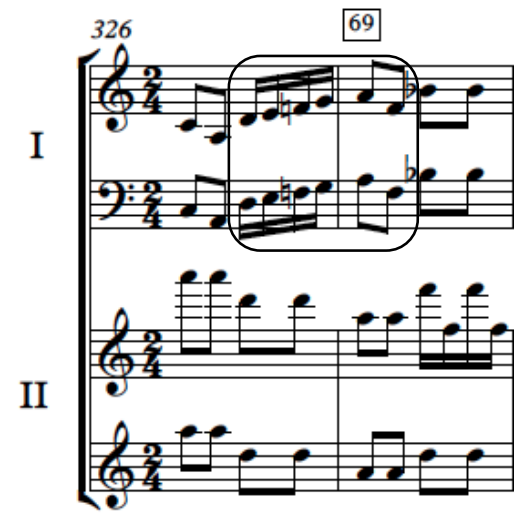

Copyright (C) 1934 (Renewed) by G. Schirmer, Inc. (ASCAP) International Copyright Secured. All Rights Reserved. Used by Permission.

Warning: Unauthorized reproduction of this publication is prohibited by Federal Law and is subject to criminal prosecution

(b)

"The Mechanical Doll” is in ternary form (ABA'), with section A in measures 1-16. The piece opens with a two-bar motif of sixteenth and eighth notes with $2+2+4$ phrasing. Section $B$ (mm. 17-29) is built from an open fifth droning in G, as if the doll is dancing (see Example 6.6.3). 


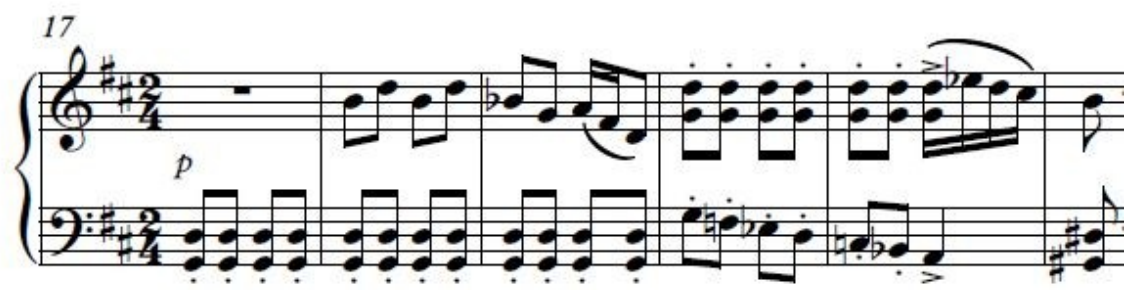

Copyright (C) 1945 (Renewed) G. Schirmer, Inc. (ASCAP) International Copyright Secured. All Rights Reserved. Used by permission of G. Schirmer, Inc. (ASCAP)

Section $A^{\prime}$ (mm. 30-45) returns after the dynamic surprise in $\mathrm{m} .29$, but this time the left hand has the $16^{\text {th }}$-note melody. (See Example 6.6.4)

Example 6.6.4 Dmitri Shostakovich A Child's Exercise Book, Op. 69, "VI. Mechanical Doll” mm. 30-31

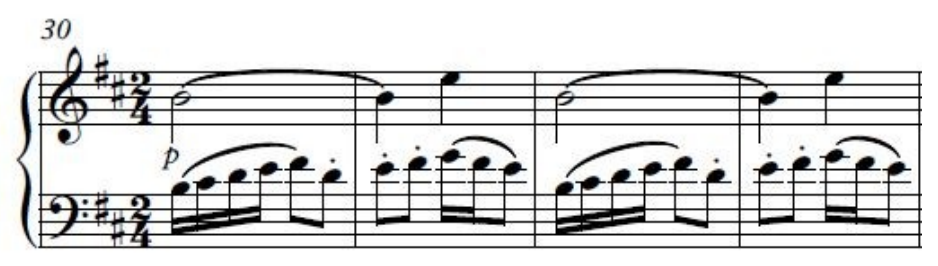

\section{Copyright (C) 1945 (Renewed) G. Schirmer, Inc. (ASCAP) International Copyright Secured. All Rights Reserved. Used by permission of G. Schirmer, Inc. (ASCAP)}

This particular movement can help students to develop dexterity with the five-finger patterns. Evenness of touch as well as independence of the fingers is required to project the clean articulation. This works makes an effective etude.

\section{"Birthday"}

The last piece of the set, "Birthday," was added to the set one year after Shostakovich had completed the other six pieces in A Child's Exercise Book, Op. 69 as Galina's ninth birthday present. This can be a good alternative to the conventional Happy Birthday song as students will 
not only be playing this for a special occasion, but perhaps also as a first twentieth-century piano composition.

"Birthday" is written in A major without a tempo marking at the top of the score.

Shostakovich wrote this movement in a through-composed structure, with an introduction in the beginning and a coda at the end. The introduction (mm. 1-6) features a triplet figure similar to a trumpet fanfare, as used for celebrations (see Example 6.7.1). Interestingly, this opening theme is reminiscent of the composer's Festive Overture, Op. 96, and Peter I. Tchaikovsky's ballet suite, The Nutcracker, Op. 71a, "March of the Toy Soldiers." This is probably because both "Birthday" and "Christmas" are festive occasions. In section A (mm. 7-16), Shostakovich brings back a waltz-like left hand accompaniment similar to the material from the prior movement, "Waltz."

Example 6.7.1 Dmitri Shostakovich, A Child’s Exercise Book, Op. 69, "VII. Birthday,” mm. 1-6

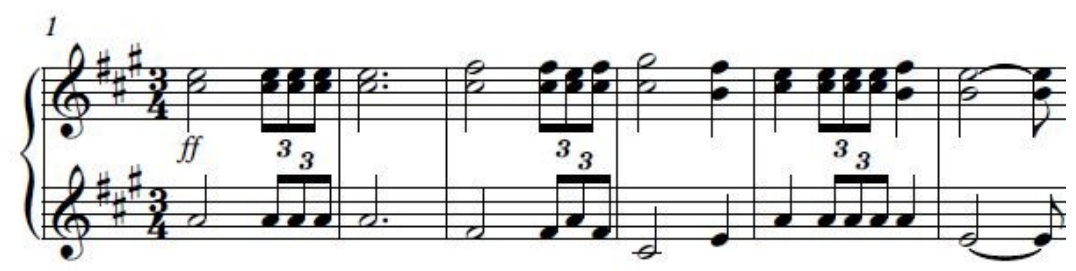

Copyright (C) 1945 (Renewed) by G. Schirmer, Inc. (ASCAP) This arrangement copyright (C) 1986 by Edwin F. Kalmus \& Co., Inc.

In section B (mm.17-24), the composer sporadically brings the triplet figuration back. However, the left hand still maintains a waltz-like accompaniment. 
Example 6.7.2 Dmitri Shostakovich, A Child's Exercise Book, Op. 69, "VII. Birthday," mm. 24-25

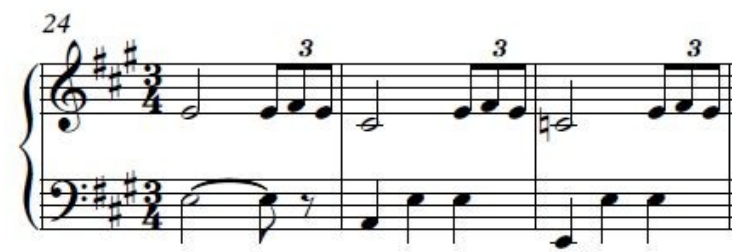

Copyright (C) 1940 (Kenewed) by (i. Schirmer, Inc. (ASCAP)

This arrangement copyright (C) 1986 by Edwin F. Kalmus \& Co., Inc.

Next, a group of four sixteenth notes is presented for the first and only time in this piece, which leads the section to its conclusion in measure 32 (see Example 6.7.3).

Example 6.7.3 Dmitri Shostakovich, A Child's Exercise Book, Op. 69, "VII. Birthday," mm. 29-30

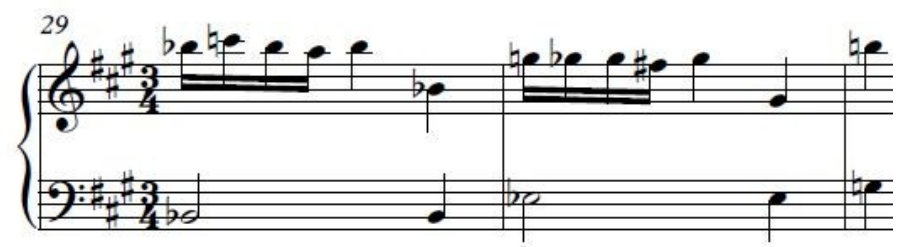

Copyright (C) 1945 (Renewed) by G. Schirmer, Inc. (ASCAP) This arrangement copyright (C) 1986 by Edwin F. Kalmus \& Co., Inc.

The next section, section D (mm. 33-40), boasts open fifths triplets that are featured in the right hand (see Example 6.7.4).

Example 6.7.4 Dmitri Shostakovich, A Child's Exercise Book, Op. 69, "VII. Birthday," mm. 33-36

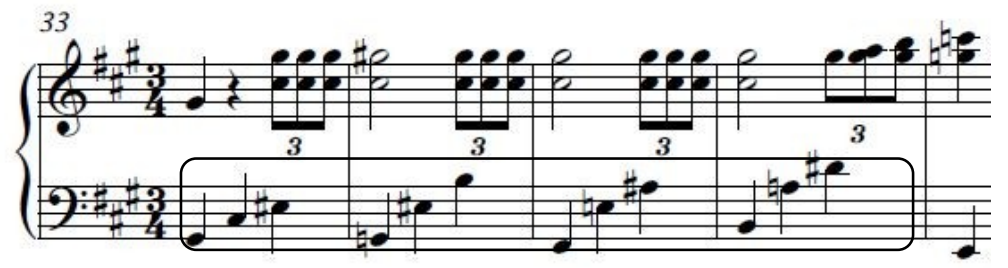

Copyright $\mathbb{C} 1945$ (Renewed) by G. Schirmer, Inc. (ASCAP) This arrangement copyright $(\mathcal{1} 1986$ by Edwin F. Kalmus \& Co., Inc.

This left-hand spacing figuration is also typical of Shostakovich's larger works such as Piano Concerto No. 1, Op.35. (see Example 6.7.5). 
Example 6.7.5 Dmitri Shostakovich, A Child's Exercise Book, Op. 69, "VII. Birthday," measure 17

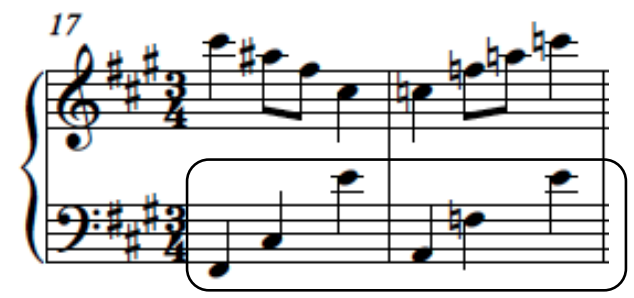

Copyright $\mathbb{C} 1945$ (Renewed) by G. Schirmer, Inc. (ASCAP)

This arrangement copyright (C) 1986 by Edwin F. Kalmus \& Co., Inc.

Example 6.7.5a Dmitri Shostakovich, Piano Concerto No. 1, Op.35, (fourth movement). mm. 391-394

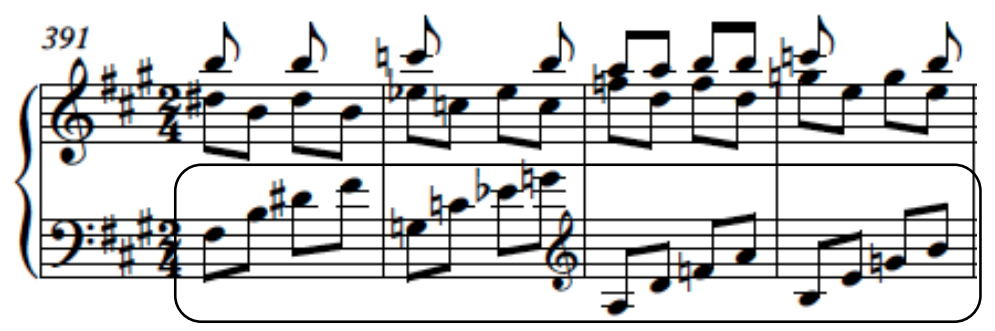

Copyright (C) 1934 (Renewed) by G. Schirmer, Inc. (ASCAP) International Copyright Secured. All Rights Reserved. Used by Permission.

Warning: Unauthorized reproduction of this publication is prohibited by Federal Law and is subject to criminal prosecution

In the penultimate section $\mathrm{E}(\mathrm{mm} .41-48)$, the melody is presented in the right hand while the left hand plays a complimentary rhythm on the second and third beats in mm. 41-44 (See

Example 6.7.6), then vice versa in mm. 45-48 (see Example 6.7.6).

Example 6.7.6 Dmitri Shostakovich, A Child's Exercise Book, Op. 69, "VII. Birthday," mm.41-44.

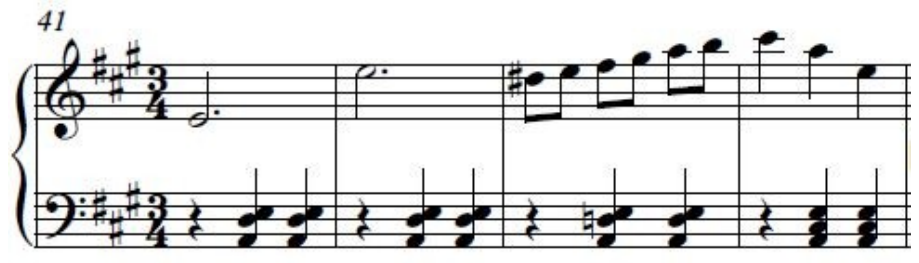

Copyright (C) 1945 (Renewed) by G. Schirmer, Inc. (ASCAP) This arrangement copyright (C) 1986 by Edwin F. Kalmus \& Co., Inc. 
Example 6.7.7 Dmitri Shostakovich, A Child's Exercise Book, Op. 69, "VII. Birthday,” mm.45-46.

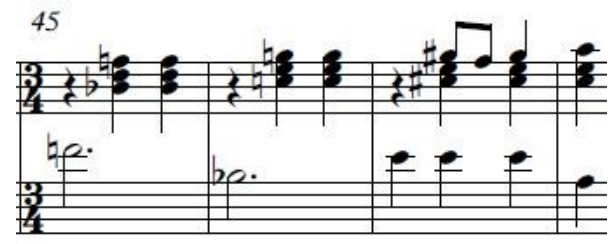

Copyright (C) 1945 (Renewed) by G. Schirmer, Inc. (ASCAP)

This arrangement copyright $(C) 1986$ by Edwin F. Kalmus \& Co., Inc.

Finally, the composer brings back the triplet fanfare once again in the coda (mm. 48-53)

. (See Example 6.7.8)

Example 6.7.8 Dmitri Shostakovich A Child's Exercise Book, Op. 69, "VII. Birthday," mm. 49-53

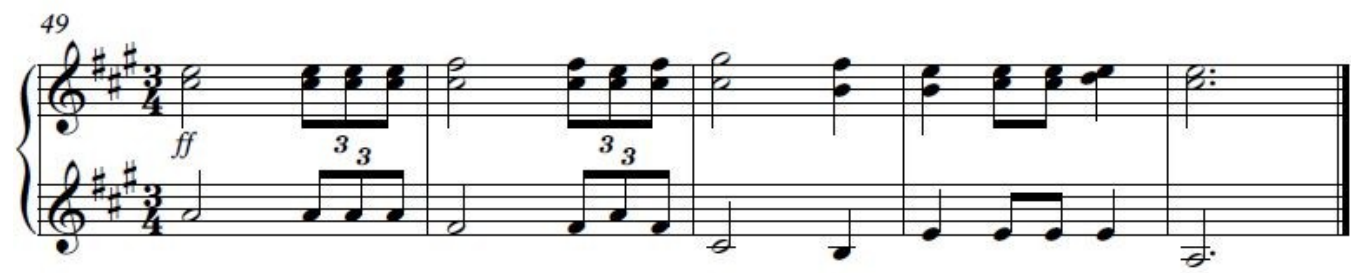

Copyright $(1) 1945$ (Renewed) by G. Schirmer, Inc. (ASCAP) This arrangement copyright (C) 1986 by Edwin F. Kalmus \& Co., Inc.

This movement is also at the middle intermediate level like the previous pieces, provides an excellent introduction to Shostakovich's music. A Child's Exercise Book represents a particularly effective collection for developing students' reading abilities, hand independence and musical maturity. 


\section{CHAPTER SEVEN}

\section{Sonatine for Yvette by Xavier Montsalvatge (1912-2002)}

A Spanish composer and critic, Xavier Montsalvatge was born in Barcelona, Spain in March 1912. He is one of the most important figures in the Catalan musical tradition. Catalonian music is one of the oldest musical traditions in Europe, dating from the Middle Ages. However, due to the emergence and flourishing of the Germanic musical tradition from the $17^{\text {th }}$ century until the late $19^{\text {th }}$ century, Catalonian music faded out of common knowledge during this time. According to Roger Evans in reference to Jan Morris, "Catalonia (is) one of several nations long since embedded in the side of Spain, but still recognizably master of their own character."91 Evans mentioned that a person's name sometimes tells a significant part of his/her story, and this is true with Montsalvatge:

"XAVIER (approximately pronounced $c h u b b-Y A Y$ ): for the great Francis Xavier, 'Apostle to the Indies.' Besides being one of the most eminent historical figures that the Iberian Peninsula has ever exported, he was a model of the person who gets a lot done with little fuss. In that sense the name was prophetic for our composer, who would pass on the name, received from his father, Francesc Xavier Montsalvatge i Iglésias, his own son, Xavier Montsalvatge i Pèrez.

MONTSALVATGE (approximately pronounced moon-suhl-BOT-zyuh): meaning 'wild mountain,' it is a name that fairly shouts "I am a Catalan," since it bears distinctive orthographical marks and phonological sounds of that language." 92

Unfortunately, at the age of nine, Montsalvatge experienced the death of his father,

Francesc Xavier Montsalvatge i Iglésias. He then went to stay with his maternal grandfather in

Barcelona. His unmarried aunt, Candalaria, who also lived in the same house, was a pianist, and Montsalvatge accompanied her, quite often, to the opera house. This was the way in which his

\footnotetext{
${ }^{91}$ Roger Evans, Xavier Montsalvatge: A Musical Life in Eventful Times (Hillsdale, NY: Pendregon Press, 2012$), 1$.

${ }^{92}$ Ibid, 5.
} 
musical path was initially paved. ${ }^{93}$ A few years later, he was fortunate to relocate to Girona, a Catalonian city north of Barcelona. There he attended the Montessori school.

Montsalvatge received a "child-size" violin during his pre-school years, and by age eleven, while at the Montessori school, his progress on the violin was remarkable in that he could play “de menera infantile," a Handel andante. Therefore, his family sent him to Barcelona's Municipal School of Music (Barcelona Conservatory), which required attendance three times per week, in addition to his attendance at the Montessori school. ${ }^{94}$

Montsalvatge attended the Barcelona Conservatory until he was 24 and studied with such teachers as Lluis Millet (1867-1941, solfege), Francesc Costa (1891-1959, violin), Enrique Morera (1865-1942, composition), and Jaume Pahissa (1880-1969, composition). Montsalvatge later realized that he was not suitable to be a concert violinist. Therefore, he shifted his focus to composition. Both of his composition teachers were the successors of Felipe Pedrell (18411922), a notable Spanish-Catalan composer and musicologist. ${ }^{95}$ Later in his career, Montsalvatge was awarded several prizes for his compositions during his time at the Barcelona conservatory. Those awards include the conservatory's Rebell Prize (for his Impromptus for piano) and Pedrell Prize (for his Suite burlesca). Later, in 1936, Montsalvatge was engaged more in theatrical works and had begun composing several works for ballet. Those works include $E l$ ángel de la guarda (unpublished), and La muerte enamorada (1943), Manfred (1945), and La Venus de Elna (1946) for the Goubé-Alexander company of Monte Carlo. Regarding his

\footnotetext{
${ }^{93}$ Evans, op. cit., 20.

${ }^{94}$ Ibid, 21.

${ }^{95}$ Martha Lynne Watson Violette, "The Solo Piano Music of Xavier Montsalvatge" (DMA diss., The University of Iowa, 1990), 23.
} 
teaching career, Montsalvatge taught at the San Jorge Academy, the Destino Seminary, and the conservatory. ${ }^{96}$

The compositional style of Xavier Montsalvatge is a balanced mixture between nationalism and traditionalism that incorporates twentieth-century techniques. ${ }^{97}$ When examining nationalistic elements, it is noticeable that Montsalvatge features such Spanish elements as Antillanismo with the use of habañera, and Andalusian as well as Catalonian folk music. Noteable compositions that incorporate such elements include the Habañera from the Costa Brava (1965), the second movement of Sonatine for Yvette (1960), and Microrhapsody for Cello and Piano (1976), respectively. ${ }^{98}$ Traditionalist elements in Montsalvatge's music include the use of genres from the past, such as the sonata, concerto, and partita. Works that make use of these genres include Sonatine for Yvette (1960), Concerto Poem for Violin (1950-1951), and Partita 1958 for Orchestra. ${ }^{99}$ The twentieth-century compositional techniques that Montsalvatge utilizes in his music include polytonality, clusters and micro tonality, and serialism, as well as unusual rhythmic combinations. ${ }^{100}$

Montsalvatge's overall compositional output covers a wide variety of settings, including works for the stage, film, and concert pieces. Some of his most notable are works for the piano. The time-span which Montsalvatge composed music for solo piano covers more than fifty years. His piano works are small in quantity; however, they all represent music from his different stylistic periods. Montsalvatge's solo piano works are:

\footnotetext{
${ }^{96}$ Richard Peter Paine, Montsalvatge, Xavier http://www.oxfordmusiconline.com/subscriber/article/grove/music/19042?q=montsalvatge\&search=quick\&pos=1\& start=1\#firsthit (accessed September 29, 2014).

${ }^{97}$ Violette, op. cit.,26.

${ }^{98}$ Ibid, 26-35.

${ }^{99}$ Ibid, 35-40

${ }^{100}$ Ibid, 40.
} 
- Tre Impromptus (score lost)

- Rhythms (1942) (reappeared as the final movement in the West-Indian Quartet, 1952)

- Ballet Suite for piano (1952)

- Tres Divertimentos (1941)

- Divagación (1950) (transcription of Puss-in-Boots opera, 1948)

- Sonatine for Yvette (1960)

- $\quad$ Sketch (1960)

- Alegoría a la Memoria de Joaquín Turina (Allegory to the Memory of Joaquin Turina) $(1982-1985)$

- Tres Obras para la Mano Izquierda (Three pieces for the left hand):

○ Si, a Mompou (Yes, Mompou) 1983

- Berceuse a la Memoria de Oscar Espla (Lullaby to the Memory of Oscar Espla) 1987

- Una Pagina para Rubinstein (A Page for Rubinstein) 1987.

Sonatine for Yvette was composed in 1960 for Yvette, his daughter, and was published two years later by the French music publisher Salabert. ${ }^{101}$ Although Montsalvatge wrote this piece for his daughter, he did not mention that he intended for his daughter to play this piece herself. Rather, one scholar, Martha Lynne Watson Violette, mentions what Montsalvatge wrote in the program notes of the premiere of this work explaining the purpose of the composition:

"Its title refers to the wish for an agile and youthful piece written with my daughter, Yvette, in mind. A popular children's song is included in the last movement. Nevertheless, the work, neither

${ }^{101}$ Violette, op. cit., 100. 
in its construction in the "sonata" form nor in its style, approximates what we understand as children's music." 102

Sonatine for Yvette is written in a three-movement sonata form, with traditional fastslow-fast outline. Following is a survey of each movement regarding structure, rhythm, and pedagogical issues.

\section{"Vivo e Spirito"}

The first movement presents in a basic sonata-allegro form. However, being a Sonatine (an abbreviated form of sonata) as well as contemporary, this movement diverts from a traditional sonata form. The exposition occurs from measures 1-52, without a repeat sign marked. The development is from measures 53-129, and the recapitulation is from measures 130158 with a repeat sign. Additionally, the composer has marked $d u$ signe au mot FIN as a second repeat from measures 53-92. This probably could be interpreted as the coda taken from the development section.

Montsalvatge presents two main themes in the exposition. The first theme allegremente (cheerfully) occurs in mm. 3-10 and the second theme calmato (calmly) is mm. 23-27. These two themes are not different in terms of tonality; in fact, they both utilize $\mathrm{E}$ as the tonal center for the right hand. However, the character of these two themes is the defining element that separates them. According to Violette, the first theme features a folkloristic quality (Gallega, Galician folksong) accompanied by a broken triad. ${ }^{103}$ This accompaniment part suggests the sense of polytonality in the theme. The theme itself has two parts. The first one is a step-wise figuration and the other one is comprised of triadic figurations (see Example 7.1.1).

\footnotetext{
${ }^{102}$ Violette, op. cit., 100.

${ }^{103}$ Ibid., 102.
} 
Example 7.1.1 Xavier Montsalvatge: Sonatine for Yvette, first movement, mm.3-10
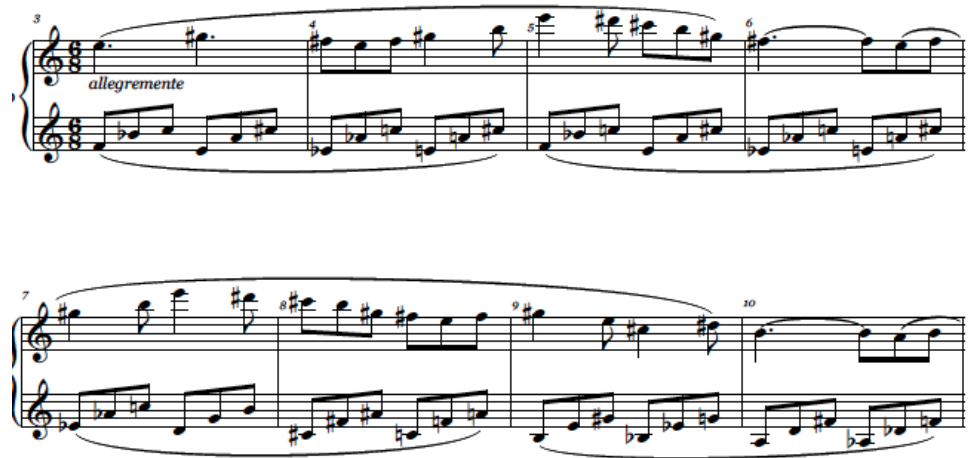

With kind permission of Editions Salabert/ Universal Music Publishing Classical

The calmato is twice as short. However, Montsalvatge utilizes a wider range of pitch choices. This section is more disjunct and dissonant, compared to the first theme. Additionally, it is accompanied by a chordal texture of triads in first inversion.

Example 7.1.2 Xavier Montsalvatge: Sonatine for Yvette, first movement mm. 23-27

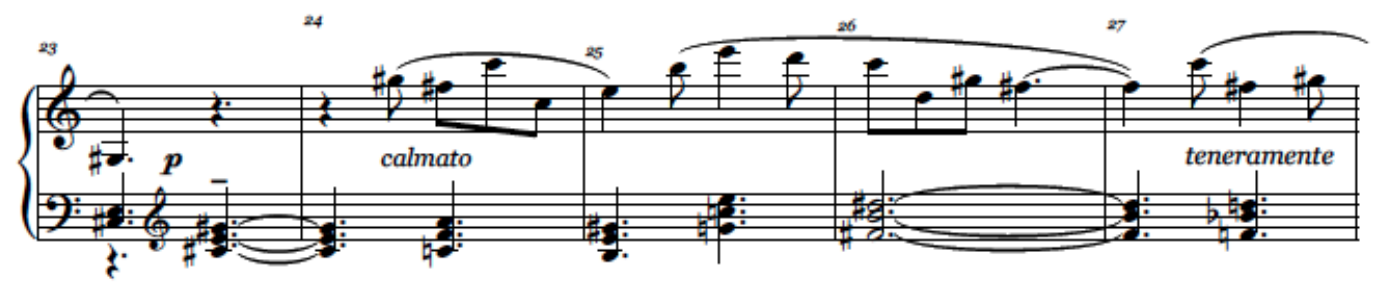

With kind permission of Editions Salabert/ Universal Music Publishing Classical

In mm. 38-42, Montsalvatge presents descending parallel octaves as a transition to the closing section of the exposition, mm. 43-52, where broken D-sharp augmented triads arpeggiate over the G-sharp pedal point, suggesting D as the tonal center (over G-sharp) (see Example 7.1.3). 
Example 7.1.3 Xavier Montsalvatge: Sonatine for Yvette, first movement mm. 38-42

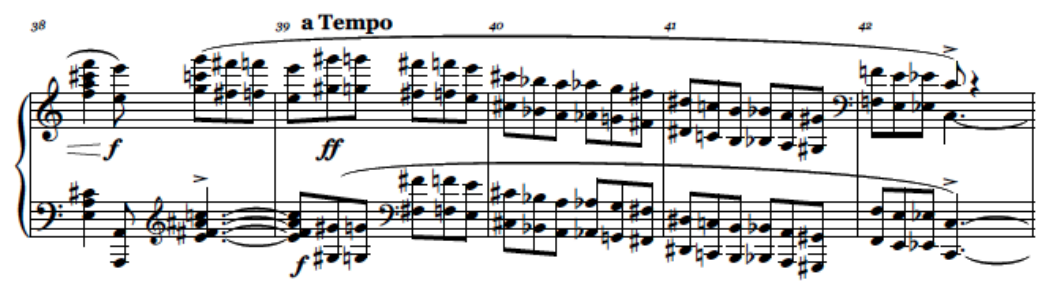

With kind permission of Editions Salabert/ Universal Music Publishing Classical

(b) mm. 43-52, closing section of the exposition
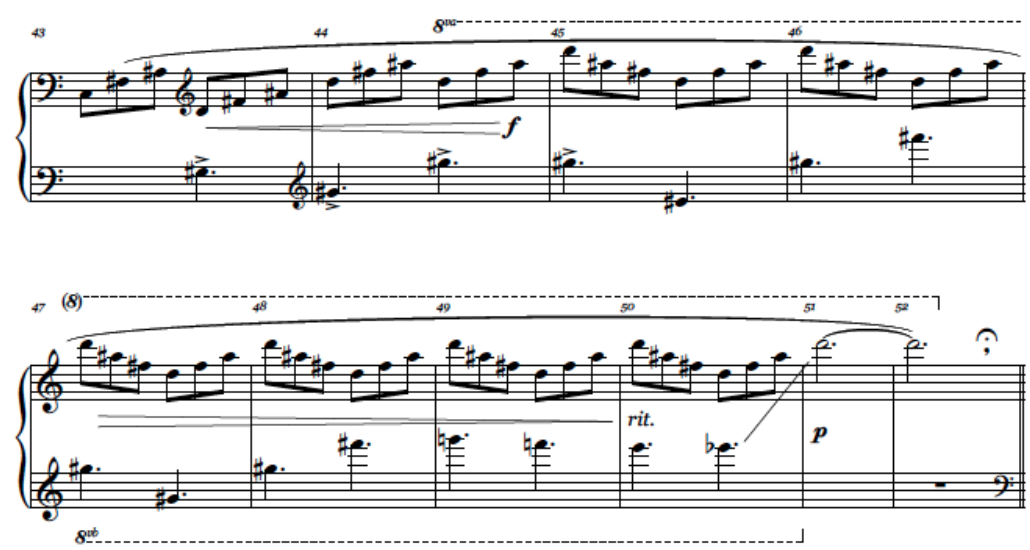

With kind permission of Editions Salabert/ Universal Music Publishing Classical

The development section is from measures 53-129. There are three main sections in the development. The first part occurs from mm.53-82, the second part is from mm. 83-92, and the final section is from mm. 93-129.

The first section of the development features new material that depicts a toccata-like quality. However, the left-hand part, such as that found in measures 53 and 59, perhaps suggests an inversion of the first two notes of the first (allegremente) theme. 
Example 7.1.4 Xavier Montsalvatge: Sonatine for Yvette, first movement, (a) mm. 53-61
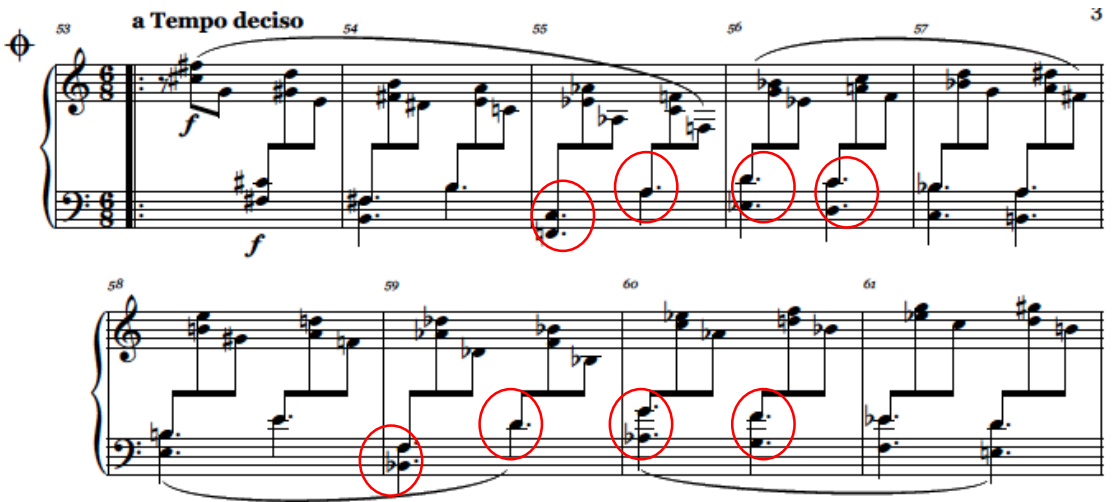

With kind permission of Editions Salabert/ Universal Music Publishing Classical

(b) mm.3-4

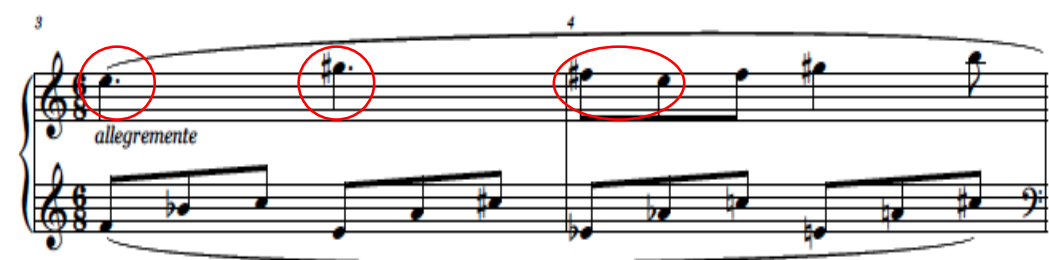

With kind permission of Editions Salabert/ Universal Music Publishing Classical

The second part of the development (mm. 83-92) features the second calmato theme, and the final part of the development, from mm. 93-129, begins with the first allegremente theme in its inversion. Additionally, there is an interesting usage of sustained pedal effects over the bar lines in $\mathrm{mm} .72-75$. 
Example 7.1.5 Xavier Montsalvatge: Sonatine for Yvette, first movement mm. 72-75

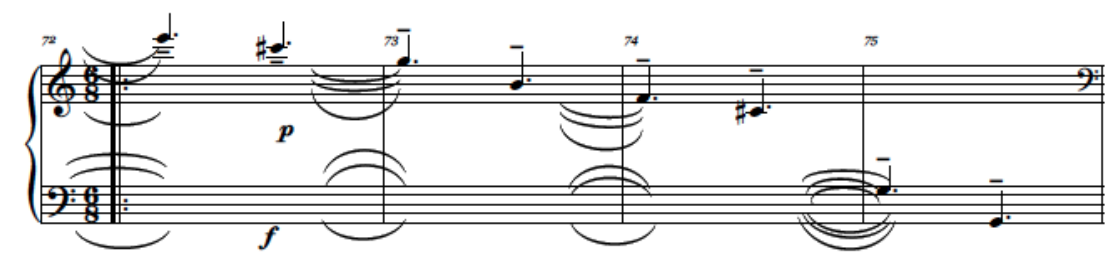

With kind permission of Editions Salabert/ Universal Music Publishing Classical

The recapitulation here is very short. The first theme recurs in measure 134 while the broken-chord accompaniment part is presented for four measures, which is twice as long as the presentation in the exposition. Instead of presenting the first theme in the tonic, the composer features the recapitulation in the G major tonality (right hand), which is a mediant relationship to E major.

Example 7.1.6 Xavier Montsalvatge: Sonatine for Yvette, first movement mm. 134-140

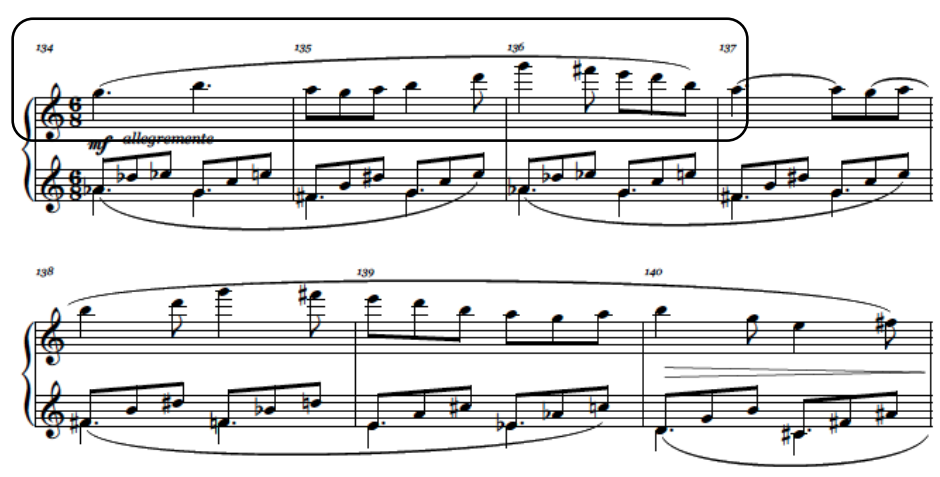

With kind permission of Editions Salabert/ Universal Music Publishing Classical

The second theme recurs in mm. 149-153 and the right hand part is in the same tonal center $(\mathrm{G}$ major) as the first theme. Montsalvatge brings the first movement to a close by writing a repeat, or coda, from measure 53 to measure 92. 
Example 7.1.7 Xavier Montsalvatge: Sonatine for Yvette, first movement mm. 149-153

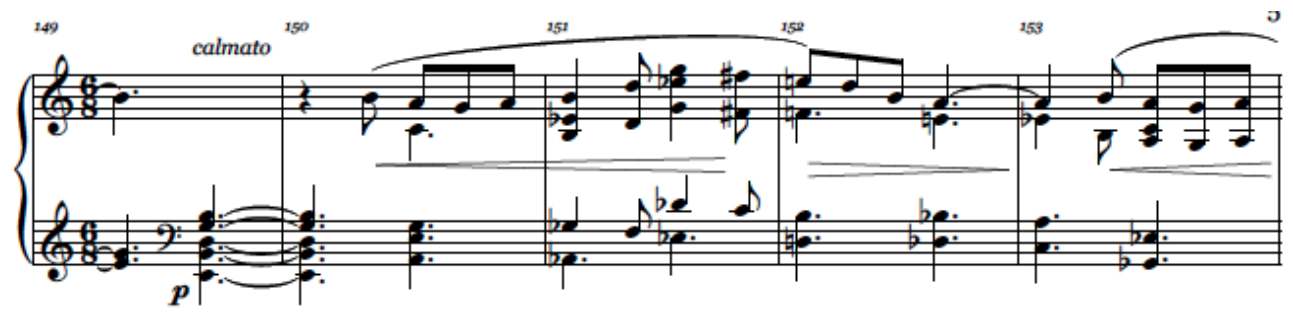

With kind permission of Editions Salabert/ Universal Music Publishing Classical

Interestingly, the recapitulation is completed by the repeat sign, together with the nontraditional indication of $d u$ segne au mot FIN. Most performers, such as Alicia de Larrocha and Mac McClure, perform this through one full time and a half time again, which brings the piece back to the first part of the development (mm. 53-82), and gives the new material in the development the effect of acting as a coda-like section.

The harmonic progression in Sonatine is nontraditional. The harmonies are chromatic in nature and employ some interesting dissonances which create a vibrant color throughout. The triads in the accompaniment do not imply a definite functional harmony. ${ }^{104}$ In terms of rhythm, Montsalvatge focuses on the compound rhythm of 6/8 in different groupings with a cheerful and vibrant character for the performer to depict.

Pedagogical concerns of the first movement mostly concern a virtuosic quality in piano playing. Students might want their first access to this movement to be hands separate, so that they will become accustomed to the sounds of this piece, which can tend to be especially challenging when first put together; as throughout this work, the sound is very polytonal in nature. Another concern is the physical reading of the piece. Montsalvatge begins the movement with two treble clefs, and the clefs in the left hand change frequently throughout the piece. The

\footnotetext{
${ }^{104}$ Violette, op. cit., 112.
} 
descending octaves as well as hand crossing in the closing section of the exposition (mm. 48-52) also pose a challenge. The cheerful, swinging $6 / 8$ rhythm and toccata-like figuration for alternating hands in the development are the other areas that require facile technique. The former is quite challenging in terms of speed as well as the accurate depiction of the character. The balance between voices and hands is critical as well. Moreover, the acrobatic movement throughout the entire range of the keyboard in the first movement is also challenging. Overall, this movement can be categorized at the early advanced level.

\section{II. "Moderato Molto"}

"Moderato molto" links the two outer movements together in part by its ambiguous tonality ( $\mathrm{E}$ and $\mathrm{A}$ ), which allows this movement to link the $\mathrm{E}$ tonal center of the previous movement as well as the A tonal center of the following movement. ${ }^{105}$ The structure of this movement is divided into three main parts. The first part (A) is from mm. 1-27. The second part (B) is from mm. 27-48 and the last part (A') is from mm. 49-59 and is also the shortest.

"Moderato Molto" begins with a guitar-like figuration which represents the rasgueado, ${ }^{106}$ "a term used to describe the technique of strumming the strings of the guitar in a downward or upward direction with the thumb, or other fingers of the right hand." ${ }^{107}$ A pattern similar to this appears again at the end of the third movement as a unification element for the entire Sonatine.

\footnotetext{
${ }^{105}$ Violette, op. cit., 133.

${ }^{106}$ Ibid, 121.

${ }^{107}$ Robert Strizich and JameTyler, Rasgueado http://www.oxfordmusiconline.com.www.libproxy.wvu.edu/subscriber/article/grove/music/22914?q=rasgueado\&se arch=quick\&pos=1\&_start=1\#firsthit (accessed 10/20/14)
} 
Example 7.2.1 Xavier Montsalvatge: Sonatine for Yvette, second movement, m. 1

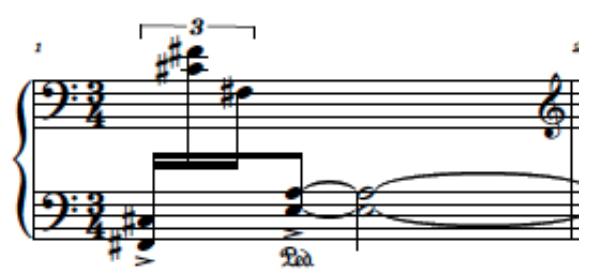

(b) third movement, measure 106

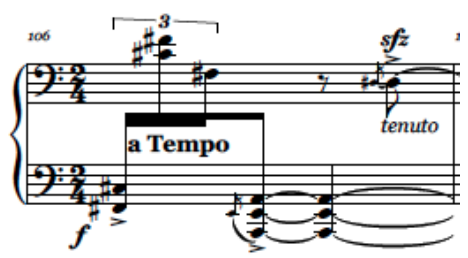

With kind permission of Editions Salabert/ Universal Music Publishing Classical

There are two main contrasting themes featured in this second movement. The first theme is presented in the A section and suggests a cante jondo like melody. According to Grove Music Online, Cante jondo (Cante hondo) is the traditional Andalusian song. ${ }^{108}$

This theme is very expressive and is complemented by cluster chords in rhythmic patterns throughout the movement.

108 "Cante hondo or Cante jondo." The Oxford Dictionary of Music, 2nd ed. rev.. Oxford Music Online. Oxford University Press, accessed October 20, 2014, http://www.oxfordmusiconline.com/subscriber/article/opr/t237/e1778. 
Example 7.2.2 Xavier Montsalvatge: Sonatine for Yvette, second movement mm. 4-8

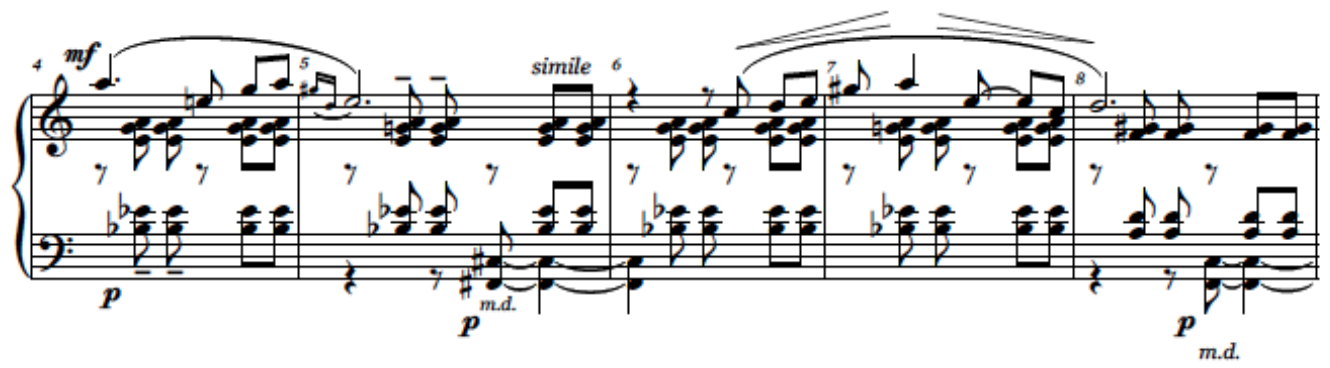

With kind permission of Editions Salabert/ Universal Music Publishing Classical

The second theme is presented in the B section. It begins and ends with an arpeggiation figure that moves from the left to the right hand and leads to a melodic idea in octaves outlining an A-flat pentatonic scale beginning from measure 29 and E pentatonic beginning from measure 37.

Example 7.2.3 Xavier Montsalvatge: Sonatine for Yvette, second movement mm. 29-30

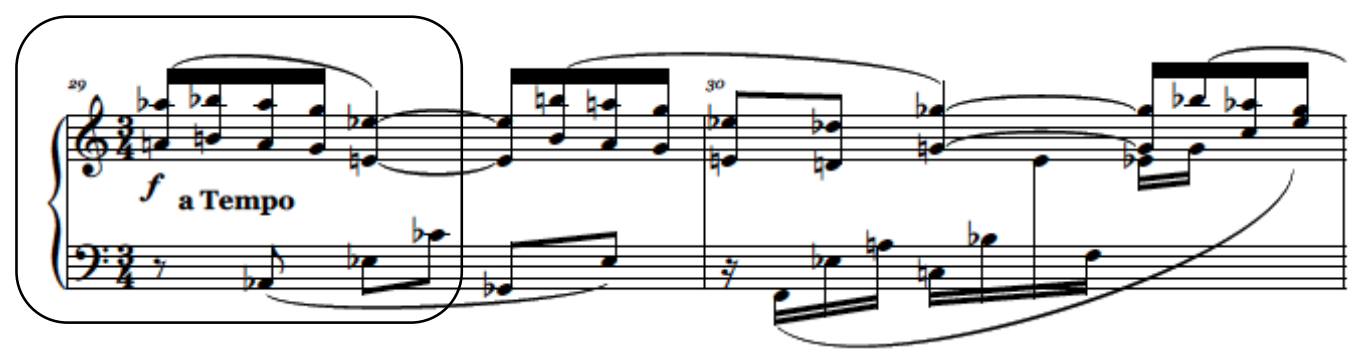

With kind permission of Editions Salabert/ Universal Music Publishing Classical 
mm. 38-39

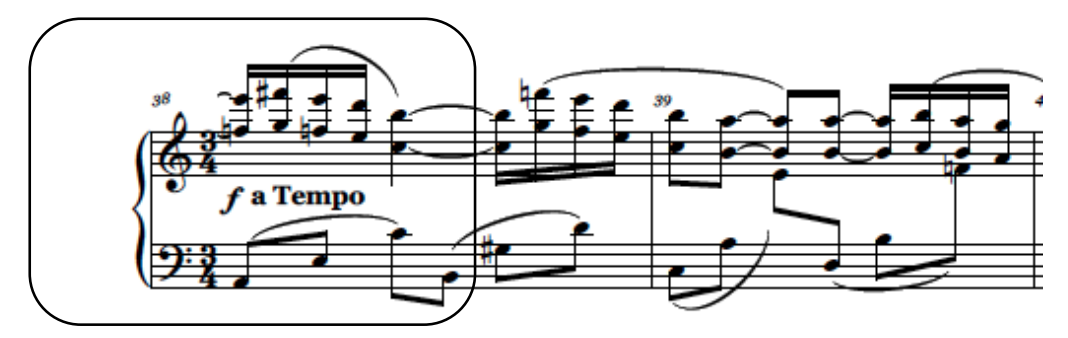

With kind permission of Editions Salabert/ Universal Music Publishing Classical

The first theme returns again in measure 49 suggesting a very brief A' section. The harmony in this second movement is chromatic and very expressive. An ostinato pattern is used as an accompaniment to the first theme. Here the composer also marks staccato notes, which resembles the plucking sound of strings, perhaps reminiscent of a guitar.

Example 7.2.4 Xavier Montsalvatge: Sonatine for Yvette, second movement mm. 2-5

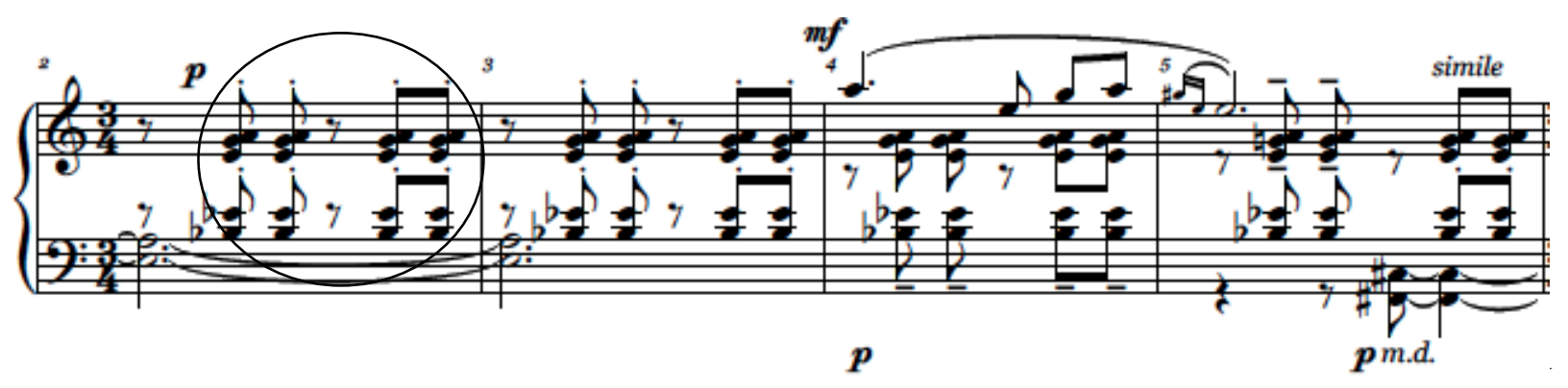

With kind permission of Editions Salabert/ Universal Music Publishing Classical

atmosphere. Montsalvatge writes the beginning of the movement in two bass clefs and expands the movement to the upper range of the keyboard 
Example 7.2.4 Xavier Montsalvatge: Sonatine for Yvette, second movement m. 1

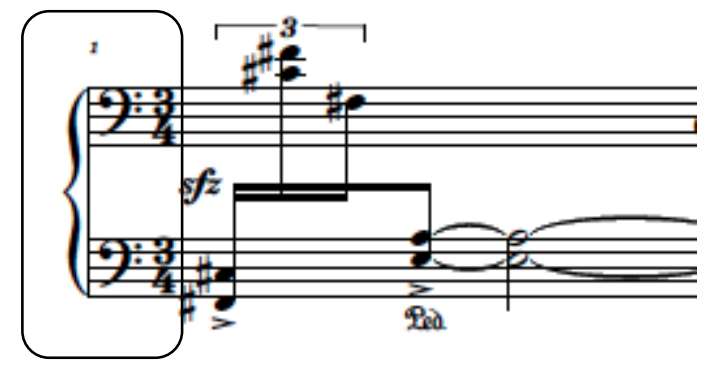

With kind permission of Editions Salabert/ Universal Music Publishing Classical

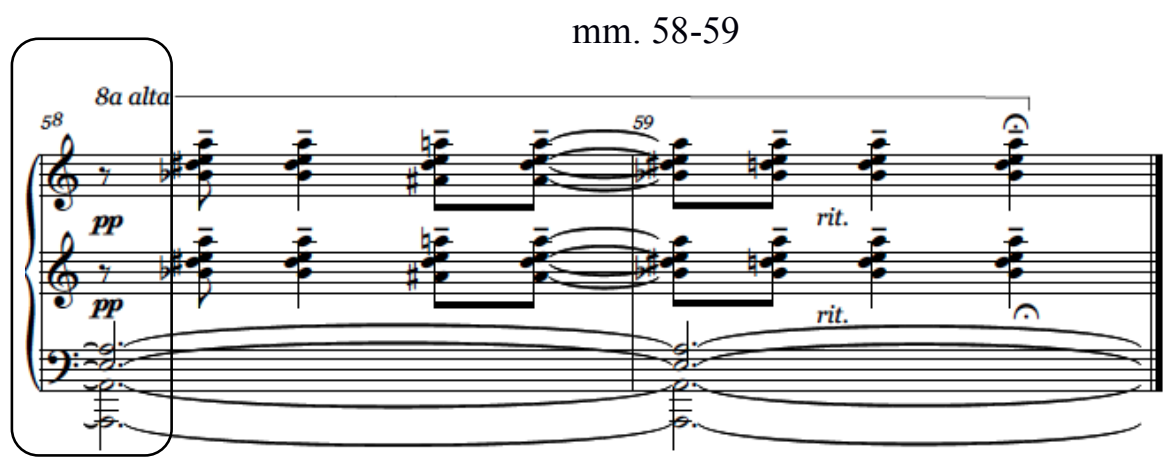

With kind permission of Editions Salabert/ Universal Music Publishing Classical

Montsalvatge uses 3/4 as the meter for this movement, along with uncomplicated rhythms. However, there is some syncopated playing, tied groupings, and a number of triplet markings.

The pedagogical issues of this movement mainly concern the expressive elements of the piece. Those elements include tempo rubato, voice balancing, sonorities, and Spanish folk elements and atmosphere. The rhythmic issues, such as playing syncopation, tied figures, and different rhythmic groupings, also present some technical challenges in terms of balance and sustained sounds. Moreover, expressive markings such as tenuto, accent, sforzando, and pesante are marked very specifically in order to suggest certain qualities of sound that the composer had 
in mind. Additionally, in the Salabert Edition, there is a usage of Spanish indications as to which register to play (such as 8a baja and 8a alta) instead of the more traditional use of Italian terms. Overall, this is an excellent movement for students to access and discover Spanish influences in a twentieth-century piece. It is at the early advanced level as well.

\section{III. "Allegretto"}

The third movement of the Sonatine is considered the most popular movement of the three with the use of a famous tune, Ah vous dirais-je, maman, or Twinkle, Twinkle Little Star. Montsalvatge features Antillanismo influences in this movement in the introduction, which features Spanish rhythmic figurations.

Like the second movement, the structure of "Allegretto" is in three parts. This movement opens with 26 measures that act as an introduction preceding the famous children's folk tune from Ah, vous dirais-je, maman. The introductory passage is from mm. 1-26. The A section is from $\mathrm{m} .26-61$, and the B section is from $\mathrm{mm} .62-103$.

"Allegretto" depicts joyful and cheerful moments through the presentation of the children's folk tune Ah, vous dirais-je, maman. This movement opens with a virtuosic figuration of the Tresillo ${ }^{109}$ rhythm. This Tresillo rhythm is a kind of triplet figuration. The grouping of this rhythmic figuration is long-long-short, or $3+3+2$ groupings of $16^{\text {th }}$ notes.

${ }^{109}$ Violette, op. cit., 107. 
Example 7.3.1 Xavier Montsalvatge: Sonatatine for Yvette third movement mm. 1-2

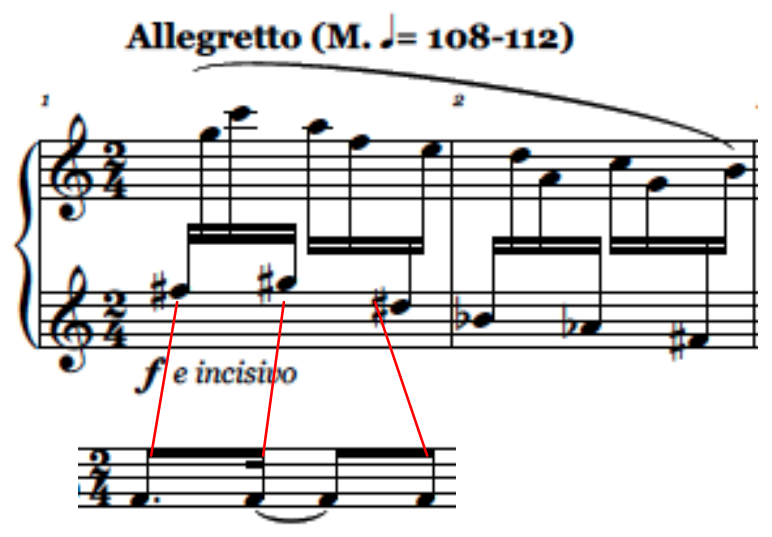

With kind permission of Editions Salabert/ Universal Music Publishing Classical

In fact, Montsalvatge writes this opening figuration simply in two groups of eight sixteenth notes. However, the composer utilizes different combinations of the hands, which creates a rhythmic effect by accentuation in the left hand and by the spacing on the keyboard. This is also similar to the piano part of the opening of his other pieces: Cinco Canciones Negras and Concerto Breve. ${ }^{110}$

To lead into the next unexpected section, Montsalvatge features a three octave whole-tone scale followed by a five-and-a-half octave glissando to the A below the bass clef in order to set up the tonal center of A. This is followed by the famous tune of Ah vous dirais-je, maman or Twinkle, Twinkle Little Star.

There are several pianists today who have recorded and performed this piece, one of whom is Montsalvatge's close friend, Alicia de Larrocha. According to Violette, de Larrocha

\footnotetext{
${ }^{110}$ Violette, op. cit., 108-109.
} 
provided an interview before her performance on March 15, 1989, published in the Denver Post as following:

"(Montsalvatge) wrote very little for piano. He has this he wrote for his daughter... and it is very well done. In the last movement the audience always laughs because suddenly comes out the theme of “Ah, vous dirais-je, Maman?"... and it is always so unexpected that people laugh."111

In this A section, Montsalvatge quotes the famous tune and narrates it in his own voice using different variations in the rhythm, re-arranging motifs in broken octaves, and changing the tune's register.

Example 7.3.3 Xavier Montsalvatge: Sonatine for Yvette, third movement

(a) $\mathrm{mm} .29-32$

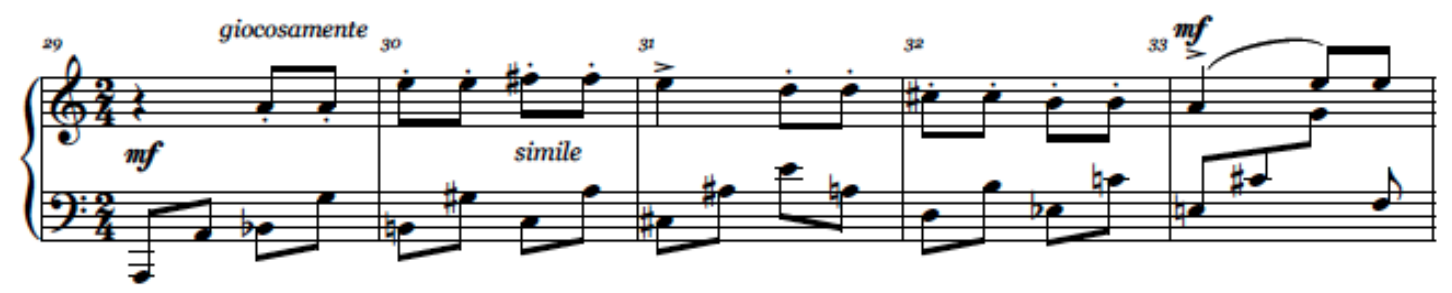

With kind permission of Editions Salabert/ Universal Music Publishing Classical

(b) mm. 35-38

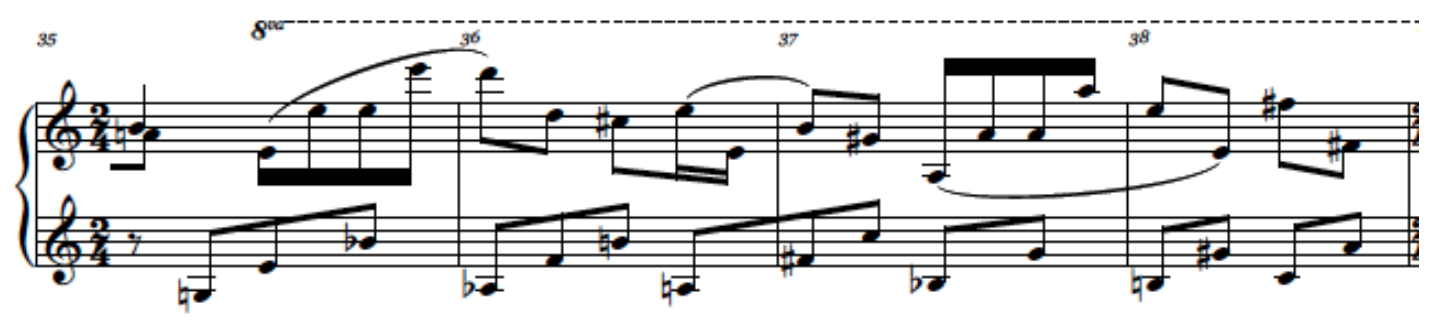

With kind permission of Editions Salabert/ Universal Music Publishing Classical

${ }^{111}$ Violette, op. cit., 119. 
(c) mm. $42-45$

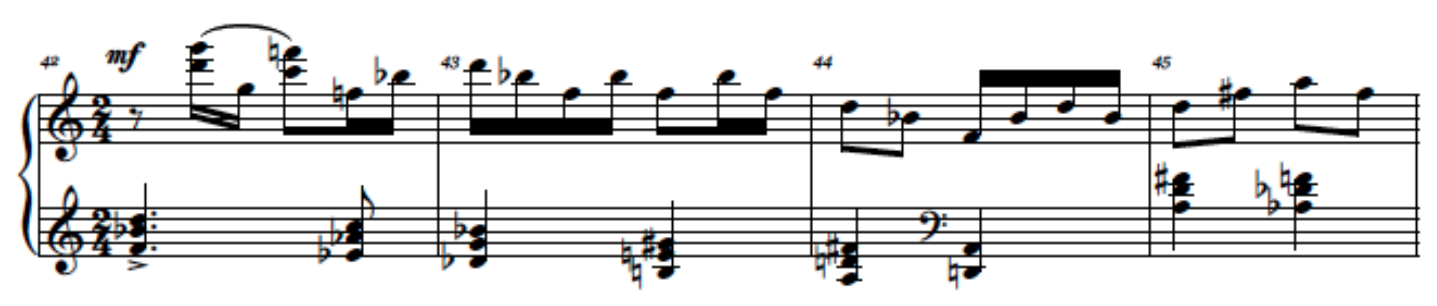

With kind permission of Editions Salabert/ Universal Music Publishing Classical

The following B section, section B, is marked meno mosso. The beginning is an inversion of the previous Ah vous dirais-je Maman. The ending of this section is similar to the beginning of the second movement, rasgueado.

Example 7.3.4 Xavier Montsalvatge: Sonatine for Yvette, third movement

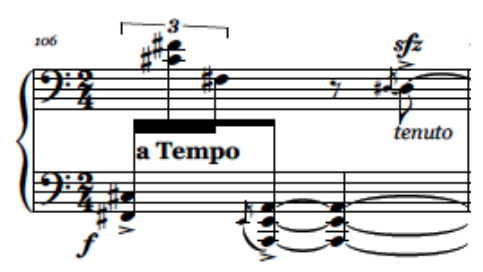

(a) $3^{\text {rd }}$ movement

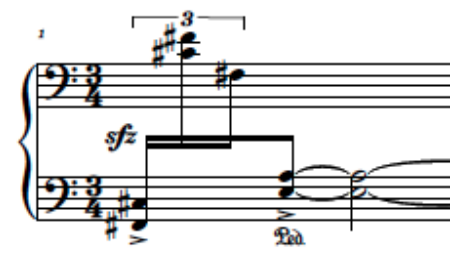

(b) $2^{\text {nd }}$ movement

With kind permission of Editions Salabert/ Universal Music Publishing Classical

In terms of rhythmic figurations, the triplet idea from the introduction returns in the $\mathrm{B}$ section in the accompaniment part. However, this time the figure is an even grouping of two sextuplets. 
Example 7.3.5 Xavier Montsalvatge: Sonatine for Yvette, third movement

(a) mm. 62-63

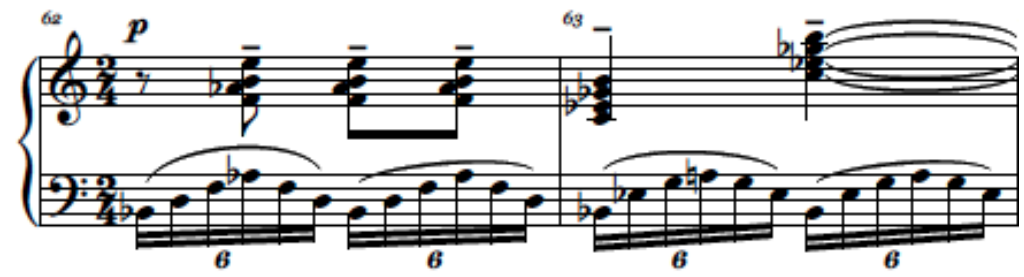

(b) mm. 73-74

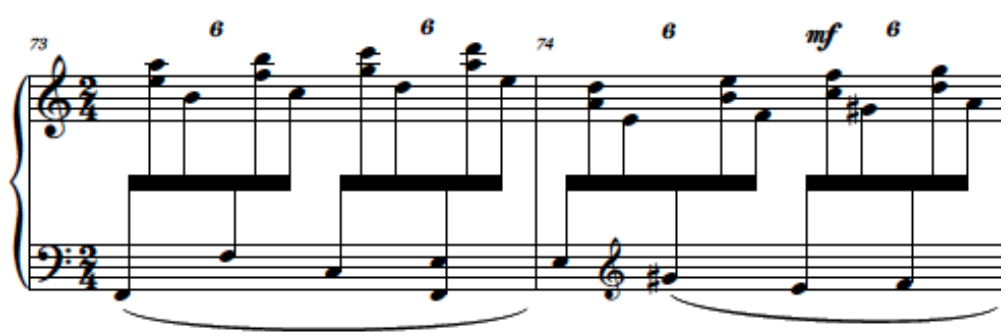

With kind permission of Editions Salabert/ Universal Music Publishing Classical

Pedagogical concerns for this movement center on the virtuosic elements: the rhythmic figurations and syncopations, and the quick speed. Students may want to try the toccata-like opening theme as well as the sextuplet figurations in the B section by blocking them together first until they are accustomed to the hand positions. Overall, this movement could be categorized as early advanced.

In summary, the whole of Sonatine is a charming, medium-length piece for students to consider as an effective recital or study piece. This piece could also be an alternative piece to the famous Sonatine by Maurice Ravel, due to its similarity in the difficulty and exuberant style. As with Dallapiccola's Quaderno musicale di Annalibera, students are encouraged to learn these movements separately and progressively. The most accessible movement to learn first would be the second movement, followed by the first, and then the third movement. Montsalvatge used 
several twentieth-century musical concepts and compositional techniques in these three movements, creating a writing style which includes lyricism, polytonality, and references to his Spanish heritage. ${ }^{112}$ He also features traditional folk elements such as Gaita Gallega music and Cante Jondo to resemble the innocence of childhood. ${ }^{113}$ According to Violette's quote from Manuel Valls, this piece is an "evanescent and refined evocation of Ravel returning fleeting to formal rule."

\footnotetext{
${ }^{112}$ Violette, op. cit., 26-35.

${ }^{113}$ Richard Paine, Hispanic Traditions in Twentieth- Century Catalan Music (NewYork: Garland Publishing, 1989), 155.
} 


\section{CHAPTER EIGHT}

\section{Family Album for piano four hands by Norman Dello Joio (1913- 2008)}

The notable and prolific twentieth-century American composer, organist, pianist, and professor Norman Dello Joio was born on January 24, 1913, in New York. Dello Joio descended from a musical Italian family. His predecessors were organists in a village church in a small town near Naples, Italy. ${ }^{114}$ Since 1829 , Dello Joio's family continued this tradition for three generations, and Norman's father, Casimiro Dello Joio (1881-1963), was the third and final family member to do so. ${ }^{115}$ Casimiro later moved to the United States and settled down first in Pittsburgh and then in New York, where he married one of his American-born Italian piano students, Antoinette Garramone (1890-1952). Their only child was Norman. ${ }^{116}$

As a family tradition, Casimiro gave Norman lessons in piano and organ as well as harmony, using the Naples Conservatory curriculum, starting when he was about five years old. ${ }^{117}$ Norman's childhood was filled with music, musicians and music-related activities, as his father was an organist, choir master, and opera coach, as well as a composer. Casimiro would observe Norman during his practice regularly and also taught him to play four-hand piano works that included everything from arrangements of classical symphonies to twentieth-century works such as Stravinsky's Petrushka. ${ }^{118}$ According to the scholar Joseph Machlis, Norman was able

\footnotetext{
${ }^{114}$ Joseph Machlis, “14. Norman Dello Joio” In American Composers of Our Time” (New York: Thomas Y. Crowell Company, 1963), 162.

${ }^{115}$ Thomas A. Bumgardner, Norman Dello Joio (Boston: Massachusetts, Twayne Publihers,1986), 1.

${ }^{116}$ Ibid, 2.

${ }^{117}$ Ibid.

${ }^{118}$ Joseph Machlis, “14. Norman Dello Joio” In American Composers of Our Time” (New York: Thomas Y. Crowell Company, 1963), 162.
} 
"to read anything at sight"119 by the age of fifteen. Around this time, he was also starting his organ lessons with his godfather Pietro Yon, who was the organist at St. Patrick's Cathedral.

Dello Joio struggled when it came time for him to contemplate his future. His possibilities ranged from becoming a professional ball player to a priest to a musician/ composer. ${ }^{120}$ His passion for music won, and he entered the Juilliard School of Music in $1939^{121}$ as a scholarship student to pursue studies in piano, organ, and composition. His composition teacher was Bernard Wagenaar (1894-1971). Dello Joio pursued his musical training in the Juilliard Graduate School as a composition major from 1939-1941. ${ }^{122}$ While he was in graduate school, he also worked as an organist at St. Anne's church in New York. However, D. J. made a decision to follow his own path after his graduation by resigning from the church-organist position at St. Anne's and ending the family tradition in order to begin his composition career. ${ }^{123}$ After he graduated, D. J. attended the Berkshire Music Center at Tanglewood, Massachusetts. While there, he met the famous German composer Paul Hindemith, who inspired him and influenced his attitude on composition as well as his perspective on the twentieth-century music world. After his time at Tanglewood, Norman commuted to Yale University to take lessons with Hindemith for one year.

\footnotetext{
${ }^{119}$ Machlis, op. cit., 162

${ }^{120}$ Ibid., 164.

121 “Norman Dello Joio Biography,” dellojoio.com. http://www.dellojoio.com/biography.htm (accessed November 1, 2014)

${ }^{122}$ Thomas A. Bumgardner, Norman Dello Joio (Boston: Massachusetts, Twayne Publihers,1986), 8.

${ }^{123}$ Ibid, 11
} 
Norman's compositional style was influenced by Italian opera, church music (Gregorian chant and other Roman Catholic liturgical music), jazz, and neoclassicism. ${ }^{124}$ His overall compositional output is large and of a wide variety, including works for choir, orchestra, band, solo voice, organ, and chamber ensembles. He also wrote concertos for piano, flute, and harp, a concertante for clarinet, a concertino for harmonica, operas, ballets, and television scores. ${ }^{125}$ His first published work is Ballad of Thomas Jefferson for voice, $1943 .{ }^{126}$

Norman Dello Joio received numerous awards both nationally and internationally, including the Elizabeth Sprague Coolidge Award, the Town Hall Composition Award, two Guggenheim Fellowships, a grant from the American Academy of Arts and Letters, The New York Music Critics' Circle Award in 1948 and again in 1962, the Pulitzer Prize in 1957, and an Emmy Award. Moreover, in 1958, CBS featured him in a one-hour television special, "Profile of a Composer." ${ }^{127}$ Furthermore, he was awarded honorary doctorates from four colleges and universities. ${ }^{128}$

Besides being a composer, Norman also taught at Sarah Lawrence College and the Mannes College of Music and was appointed as the Dean of the Fine and Applied Arts School of Boston University. He was also in charge of directing the Ford Foundation's Contemporary Music Project from 1959-1973.

\footnotetext{
${ }^{124}$ Edward Downes “the Music of Norman Dello Joio," The Musical Quarterly Vol. XLVIII, No. 2 ( April 1962): 151. 
Dello Joio's piano composition output is quite small, especially for solo piano works. ${ }^{129}$ His piano works can be organized into three categories: 1) sonatas, 2) character pieces, and 3) pedagogical works. His solo piano works include three sonatas, two nocturnes, two preludes, two suites, two songs without words, a Capriccio, Introduction and Fantasies on a Chorale Tune, Diversions, Short Intervallic Etudes, and Concert Variants. Dello Joio also wrote Fantasy and Variations for Piano and Orchestra. Additionally, Norman also wrote several pieces for pedagogical purposes both for two and four hands, some of which were written for the musical development of his three children. ${ }^{130}$

Dello Joio married twice. His first marriage (1942-1973) was to Grace Baumgold. They had two sons and one daughter (Justin, a composer, Norman, a champion equestrian jumper, and Victoria Dello Joio, a martial arts master and teacher. After they divorced, he was married again from 1974 until his death, to Barbara Bolton, with whom he had no children.

Dello Joio began writing music for young pianists more prominently during his last two decades. He wrote such pieces as Family Album (1962) and Five Images (1966) especially for his own children in order to aid their musical development. The other pedagogical pieces that were not written specifically for his own children are Suite for the Young (1964), Lyric Pieces for the Young (1971), Diversions (1975), and Stage Parodies for piano duet (1974). ${ }^{131}$

Family Album was composed in 1962 for one piano, four hands. This set, together with Five Images for piano four hands, is dedicated to his own children and wife, as indicated in the score "To G. and V. and J. and N. Jr.," The pieces were meant to illustrate a typical, ordinary day

\footnotetext{
${ }^{129}$ Thomas A. Bumgardner, Norman Dello Joio (Boston: Massachusetts, Twayne Publihers, 1986), 93.

130“Norman Dello Joio Biography," dellojoio.com. http://www.dellojoio.com/biography.htm (accessed November 1, 2014).

${ }^{131}$ Bumgardner, op. cit., 101.
} 
as spent with the family. It is comprised of five charming character pieces with descriptive titles that are easy enough for a beginner to access and are composed in such a way that they fit well for small hands. The latter set, Five Images (1966), however, is more challenging, as his children's musical abilities had been developing over this four-year period. Dello Joio gave an interview about his composition for children as follows:

"Would you talk about how you compose for children and what it means to you?

Well, as a father I decided to give children the opportunity, instead of listening to me, to make music themselves. My oldest boy, Justin, was very musical by nature because he responded very much to music without being able to play. He was about three years old, but I could tell that he obviously had talent. So, I had him play with me as I wrote the first piece in the group I did for children, which was called the Family Album. After a few lessons, he was playing already quite well. So I even got my second son, who was much younger, into it and he just did his voice. It was kind of cute the two of them talking to one another and then me getting into the act as a father. We played the music very well, and the recording went well, and it was published. I became entranced with the idea of writing for children because I began to see the problems of a little hand, which I never encountered before. I started making a bit more advanced music for them and, to my great surprise, the publishers of these works were delighted because there seemed to be great market for this, which had never occurred to me from the point of view of sales, But they're still selling an enormous amount of music for children. It's something I've had no difficulty writing. It was so simple and I enjoyed it, and they did too."132

"This CD is called Family Album. Was the idea that members of a family could listen to, or sit at one piano, to play some of this music? Was this concept behind what you were doing?

Well, yes. It was very cute because I would get fan letters from children. One very amusing letter from a little girl stands out in my mind. I had written a jazzy little piece and she wrote, "I play this music with my grandmother, and I like it but she doesn't." That is the kind of wonderful attitude they have. I can't think off-hand of how many pieces I did, but I wrote a good quantity of work for children. Now that they're all grown up, I stopped doing it for children." 133

\footnotetext{
${ }^{132}$ Norman Dello Joio, Booklet for Complete Works for Piano "Family Album, " vol. 3, performed by Debra Torok and Marylene Dosses, Albany Records Troy 468, (CD), 2001.

${ }^{133}$ Ibid.
} 
Following is a survey of Family Album with a brief analysis of each movement and pedagogical recommendations.

\section{"Family Meeting"}

The structure of the first movement is a brief ternary form lasting 14 measures_with a repeat of the A section marked by a repeat sign. Section A lasts from mm.1-6, section B from mm.6-10, and section C from mm. 11-14. The phrasing here is four bars $(4+4+4)$.

\section{Example 8.1.1 Norman Dello Joio: Family Album, "I. Family Meeting,"}

mm. 2-5, primo and secondo.

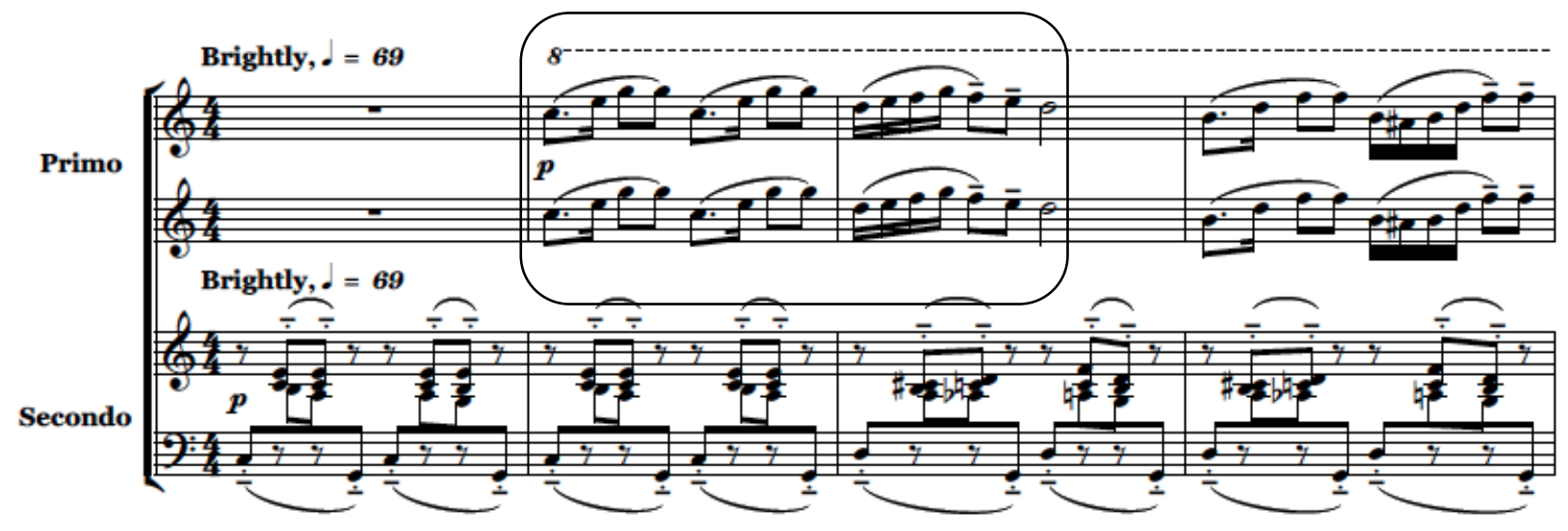

Copyright (c) 1962 Edward B. Marks Music Company

Copyright Renewed

Used by Permission

Dello Joio begins the movement with a one-measure introduction by the secondo. Next, the melody in a four-bar phrase enters in measure two in the primo. Dello Joio then exchanges the melody between the primo and secondo in measure seven. Finally, the melody returns again in measure 11. 
Example 8.1.2 Norman Dello Joio: Family Album, "I. Family Meeting," mm. 7-8, primo and secondo.

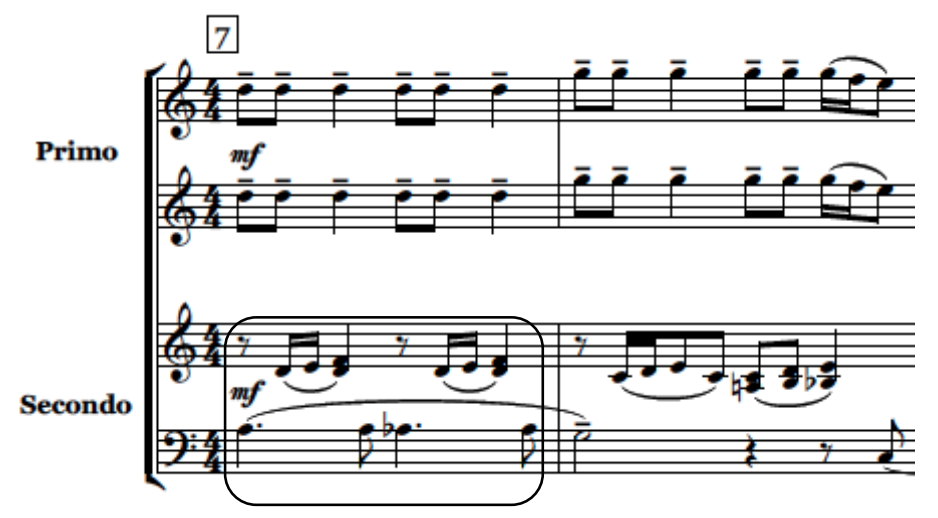

Copyright (c) 1962 Edward B. Marks Music Company Copyright Renewed Used by Permission

The composer writes in a simple $4 / 4$ time signature and the basic tonality of $\mathrm{C}$ major. However, there is some use of the extended musical language of the twentieth century such as major seventh chords and a brief use of secundal harmony.

Example 8.1.3 Norman Dello Joio: Family Album, "I. Family Meeting," mm. 2-3, secondo.

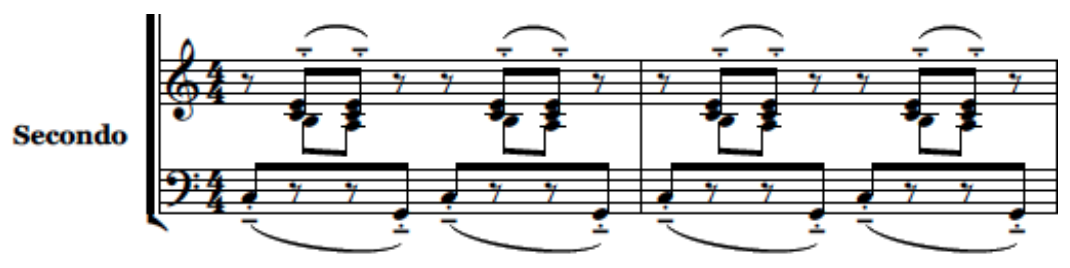

Copyright (c) 1962 Edward B. Marks Music Company

Copyright Renewed

Used by Permission

In the primo, Dello Joio uses a simple five-finger pattern, a brief extension of this

pattern, and some scale passages. The articulation here is also simple with the use of simple slur patterns as well as staccato. Perhaps, this is included in order to depict different characters 
throughout this movement. The texture here is homophonic with the melody being played by the primo in unison, and the accompaniment part played by the secondo.
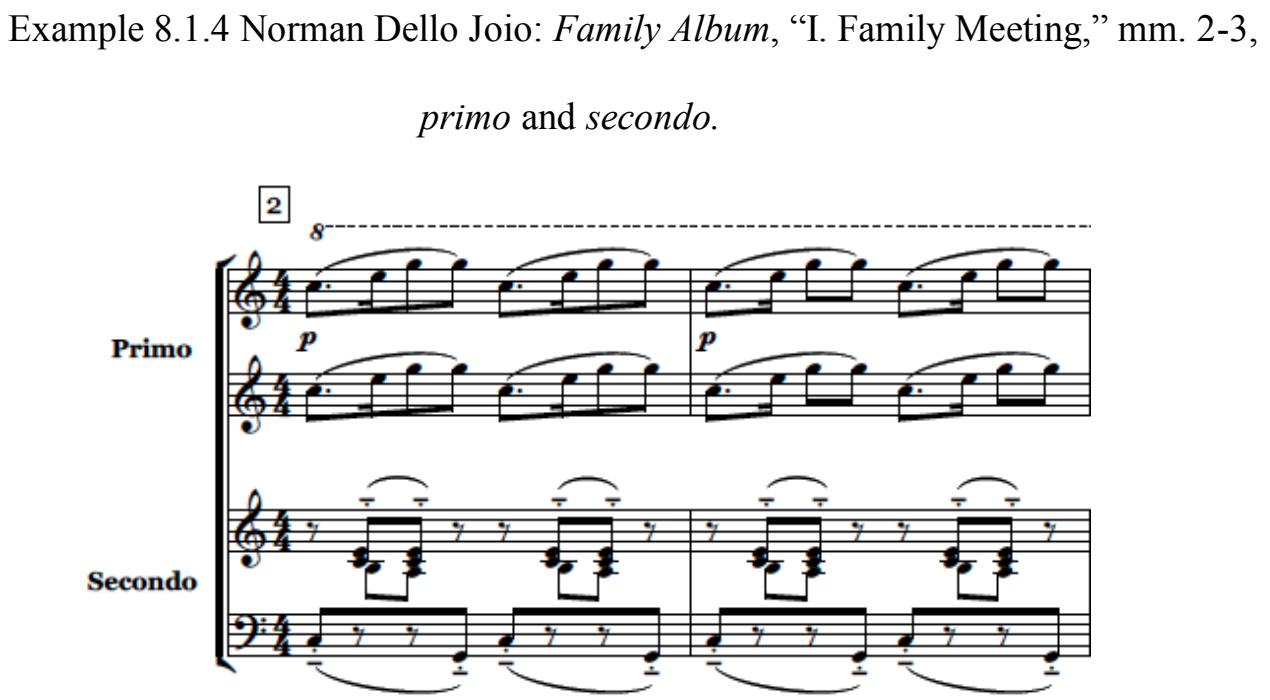
Copyright (c) 1962 Edward B. Marks Music Company Copyright Renewed Used by Permission

The piece is intended for late-elementary (primo) to middle-intermediate levels (secondo). Pedagogical issues are minimal in this movement except for the variety of touch required in the secondo and the control over the sound and balance to create the charming mood, as well as discreet pedaling in the secondo part.

\section{II. "Play Time"}

The second movement is in ternary form (ABA). Here, Dello Joio marks D.S. al fine for the return of the A section. Section A is from mm. 1-34. Section B is from mm. 35-60, and the repeat of the A section is from $\mathrm{mm} .6-34$. 
"Play Time" begins with a conversation-like introduction alternating between players in mm.1-6 (see Example 8.2.1a). All of these alternating figurations, both between parts and between hands, create the essence of the four parts of a string quartet. The right hand enters in measure 7 with the melody which gives a playful character to the movement (see Example 8.2.1b).

Example 8.2.1a Norman Dello Joio, Family Album, "II. Play Time," mm. 1-6, primo and secondo

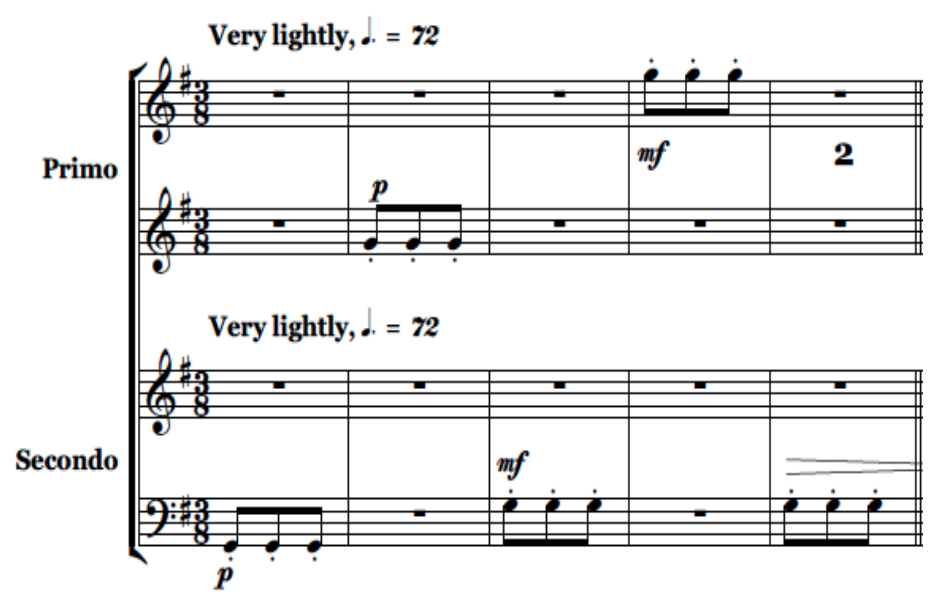

Copyright (c) 1962 Edward B. Marks Music Company Copyright Renewed Used by Permission 
Example 8.2.1b Norman Dello Joio Family Album, “II. Play Time,” mm. 7-14, primo and secondo

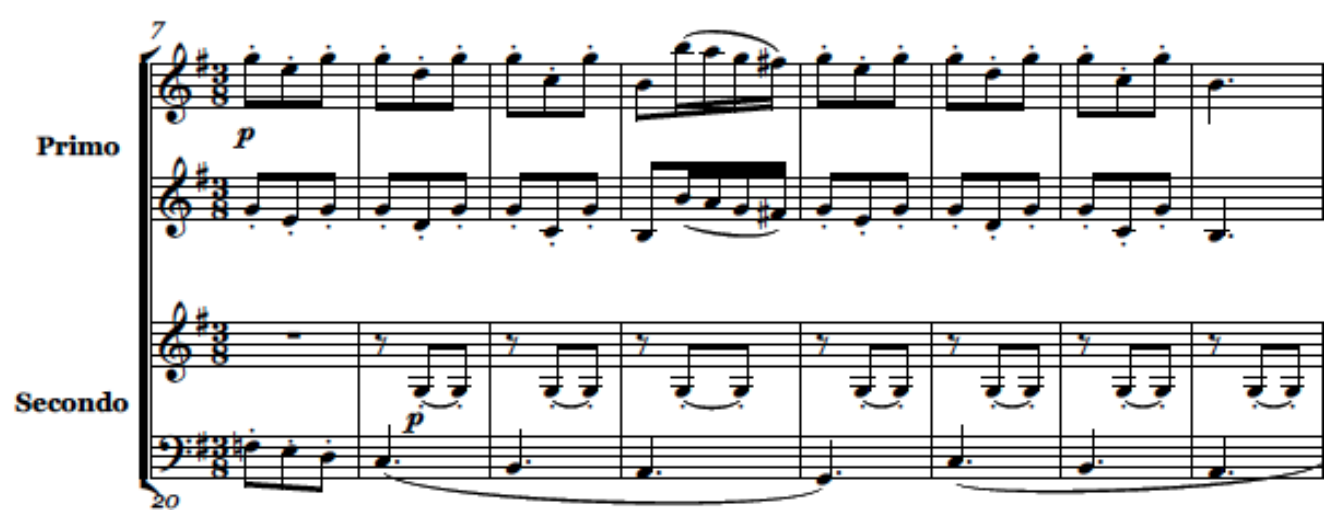

Copyright (c) 1962 Edward B. Marks Music Company Copyright Renewed Used by Permission

Dello Joio features a key change in the B section. The tonality changes from G major to E-flat major.

Example 8.2.2a Norman Dello Joio Family Album, "II. Play Time," mm. 34-35, primo and secondo

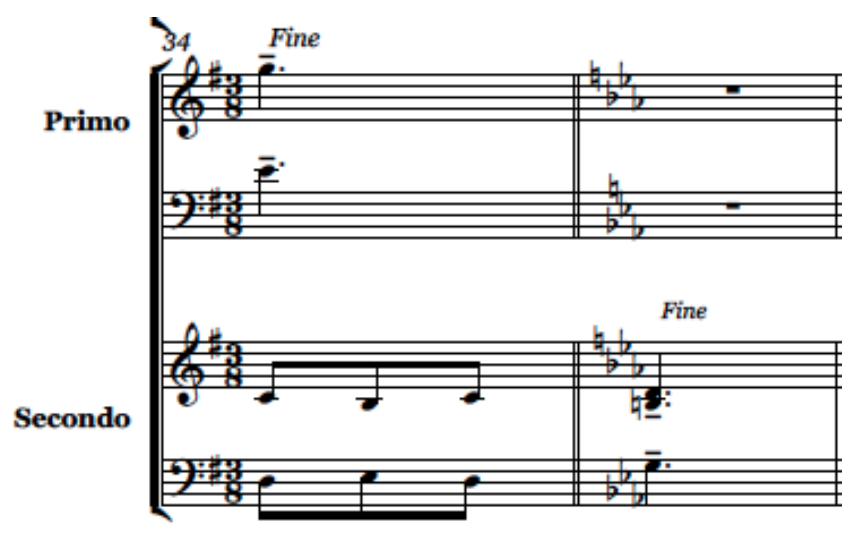

Copyright (c) 1962 Edward B. Marks Music Company Copyright Renewed Used by Permission 
The composer presents a conversation-like introduction again in a descending figure in measure 55, with a slight change: this time, the primo plays for two measures followed by the secondo for two measures, instead of alternating every other measure as in the opening. Finally, G major returns again in the last two bars of section B.

Dello Joio uses a 3/8 time signature here with staccato as the main articulation in this movement. This, together with fast and very light playing, will create a cheerful and joyful character that depicts the "Play Time" in the family.

In terms of pedagogical concerns, playing a $10^{\text {th }}$ apart in $\mathrm{mm} .23-33$ of primo, and the fast playing (as in one pulse per bar) make up the most challenging issues in this movement. Balance, ensemble, dynamic contrasts, and the crisp articulation are also all required to illustrate the character of this movement. Moreover, the continuity between the two players during the conversation-like introduction as well as the key changes are other aspects which require additional attention from students and teachers alike. In this movement, both the primo and secondo are equal in terms of difficulty and are at the early intermediate level.

\section{III. "Story Time"}

"Story Time" is a through-composed form with a coda. The A section is from mm. 1-20 as identified by the fact that Dello Joio marks a repeat sign in measure five. Section A may also be divided into two main sections with the first section in mm. 1-12 and the second in mm. 1320. The coda is from mm. 21-31. Section A first begins with a four-bar introduction in the secondo, followed by the primo entering on the second beat of measure five. 
In the primo, the right hand features a conversational melody alternating between two players in mm.4-12, the first part of the A section (see Example 8.3.1).

Example 8.3.1 Norman Dello Joio Family Album, "III. Story Time," mm. 5-8, primo and secondo

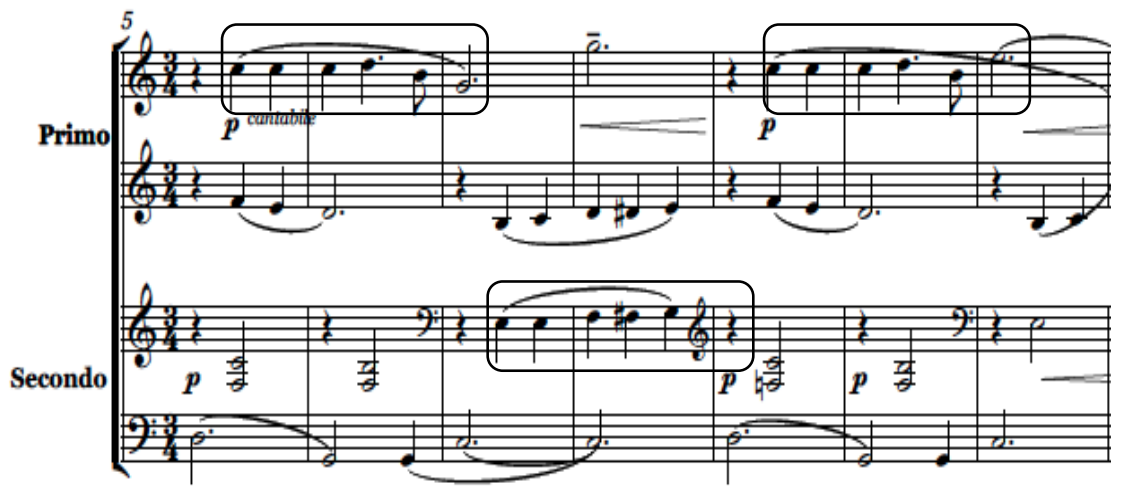

Copyright (c) 1962 Edward B. Marks Music Company

Copyright Renewed

Used by Permission

In the coda, specifically mm. 21-24, the composer utilizes figurations of ties over the bar (see

Example 8.3.2a) in the primo followed by a fragment of the motif in $\mathrm{G}$ (see Example 8.3.2b).

This brings the piece to its end while the secondo plays an accompaniment pattern (see Example 8.3.2b). 
Example 8.3.2a Norman Dello Joio Family Album, "III. Story Time," mm. 21-24, primo and secondo

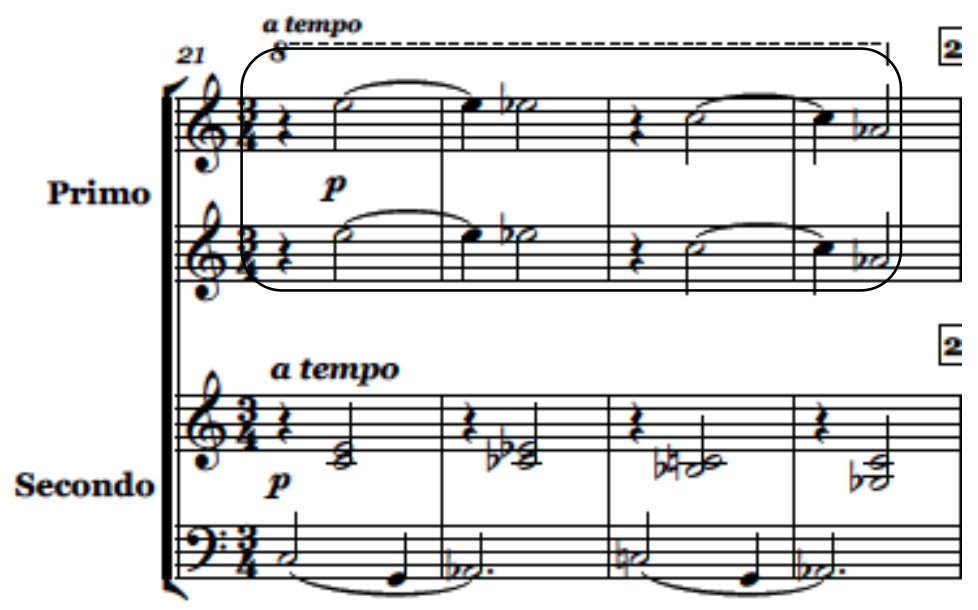

Copyright (c) 1962 Edward B. Marks Music Company

Copyright Renewed

Used by Permission

Example 8.3.2b Norman Dello Joio Family Album, "III. Story Time," mm. 25-26, primo and secondo

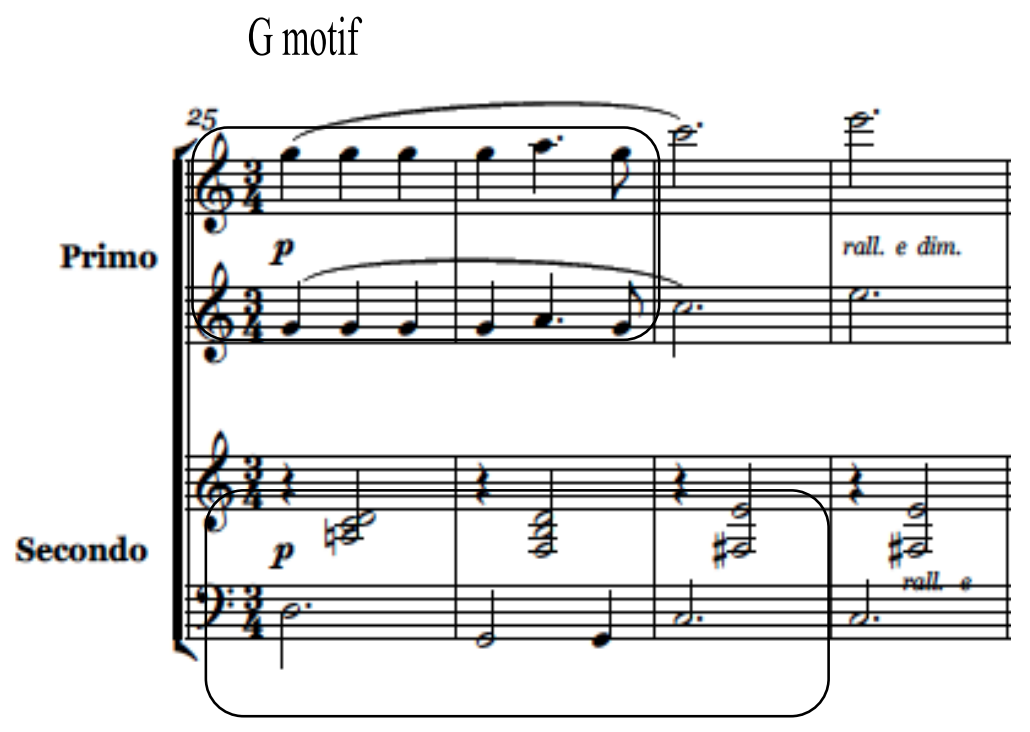

Copyright (c) 1962 Edward B. Marks Music Company

Copyright Renewed

Used by Permission 
Here, Dello Joio features the $3 / 4$ swaying rhythm. The harmony in this movement is more chromatic than the previous two, as the composer utilized some modern harmonies, including seventh and ninth chords, to give color to the "story."

In terms of texture, the composer writes in two voices for the primo in the A section and in parallel octaves throughout the B section. The secondo is playing mostly accompaniment patterns that alternate between the left and right hands (left-right or left-right-right).

Pedagogical issues in this movement mainly concern the reading of the music, which contains several accidental markings due to the more modern harmonies. The conversational character as well as the quasi-contrapuntal writing between the hands in the A section of the primo are aspects for both students and teachers to observe. Both primo and secondo parts are in the early intermediate level.

\section{IV. "Prayer Time"}

In the fourth movement of the set, the composer features one of his family's specialties organ music. "Prayer Time" is marked to be played "Like an organ." Moreover, Dello Joio also utilizes several compositional techniques typically presented in organ music in this movement, such as chorale as well as contrapuntal-style writing.

The structure of this movement is ternary form with three measures of coda. The A section occurs from measures 1-16. The B section is from measures $17-20$ and the A' section is from mm. 17-32. Finally, the coda is from mm. 33-35. 
Section A is comprised of two eight-measure phrases. Dello Joio features the use of canon in this movement. After the unison statement of the theme, Dello Joio begins the canon in measure five between the two parts (see Examples 8.4.1).

Example 8.4.1 Norman Dello Joio Family Album, "IV. Prayer Time," mm. 5-9, primo and secondo

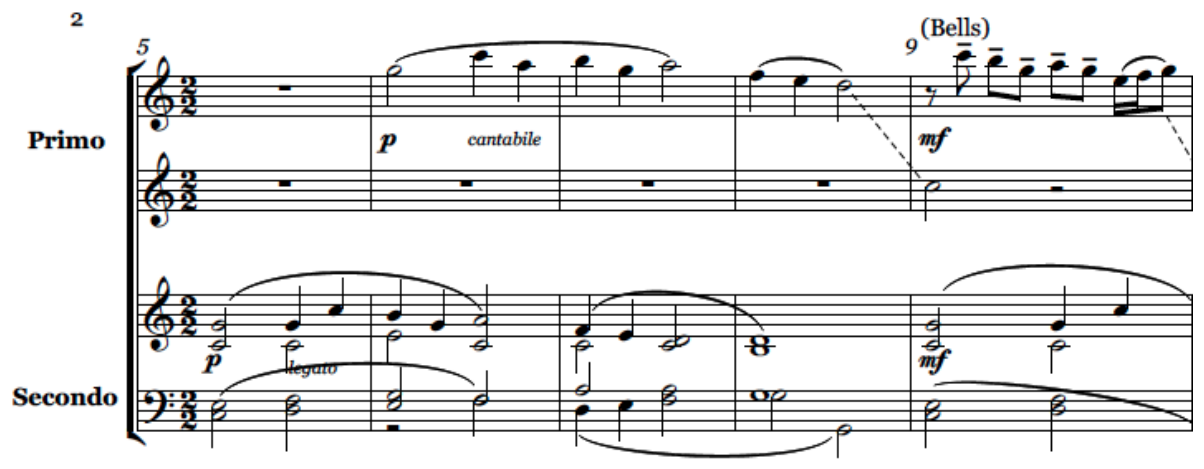

Copyright (c) 1962 Edward B. Marks Music Company

Copyright Renewed

Used by Permission

Later in section B, the composer utilizes new material in $\mathrm{mm}$. 17-20, which begins with an inversion of the first two notes of the main theme in primo.

Example 8.4.2 Norman Dello Joio Family Album, "IV. Prayer Time," mm. 17-20, primo and secondo

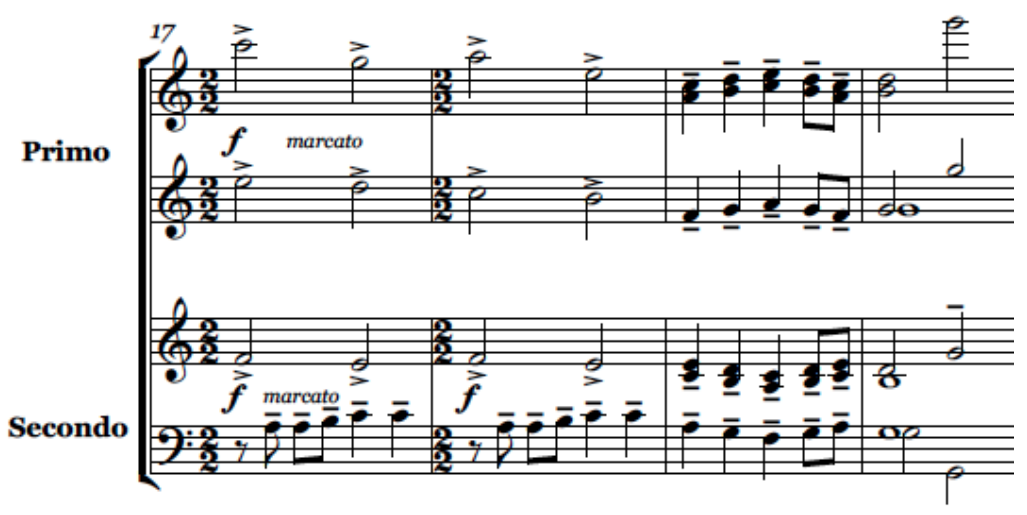

Copyright (c) 1962 Edward B. Marks Music Company

Copyright Renewed

Used by Permission 
Section A' returns again in measure 21. However, this time it is played with a much thicker texture of five voices in octaves. Finally, the composer completes this movement peacefully, with a three-measure hymn-like conclusion.

Regarding meter, Dello Joio utilizes $2 / 2$ time here, with a traditional harmonic progression in the key of $\mathrm{C}$ major.

Pedagogical aspects of this movement include the imitation of organ playing, the canon, and voicing the four-part choral texture, as well as maintaining good legato. Both the primo and secondo could be categorized at the early-intermediate level.

\section{V. "Bed Time"}

Dello Joio features "Bed Time" as looking back at what has been accomplished throughout the day, with reminiscences of the earlier pieces in the Family Album. Here, the motif from "Family Meeting" is brought back as a unification element for the whole set, and indeed acts as a memory of the previous movements.

The structure of the movement is a brief ABA' form. The A section is from mm. 1-6. The B section is from mm. 7-10, and the return of the A, or A', section is from mm. 11-15. The composer features a bell-like motif alternating between the primo and the secondo in higher and lower registers, respectively, in the A section (see Example 8.5.1). 
Example 8.5.1 Norman Dello Joio, Family Album, "V. Bed Time," mm. 1-2, primo and secondo

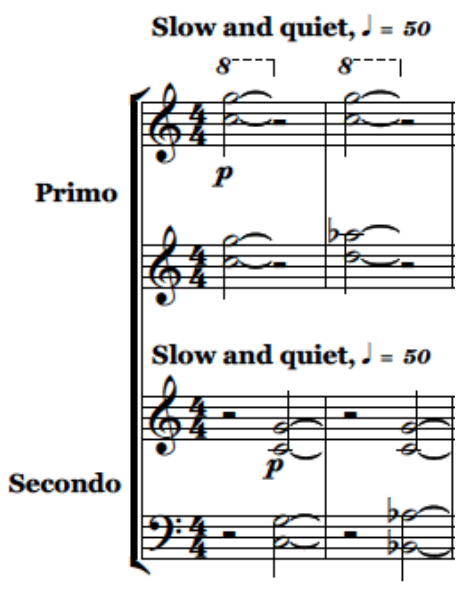

Copyright (c) 1962 Edward B. Marks Music Company

Copyright Renewed

Used by Permission

In the B section, Dello Joio brings back the main theme from I. "Family Meeting" and arranges it into a two-bar imitation between the primo and secondo consecutively (see Example 8.5.2).

Example 8.5.2 Norman Dello Joio, Family Album, "V. Bed Time," mm. 7-10, primo and secondo

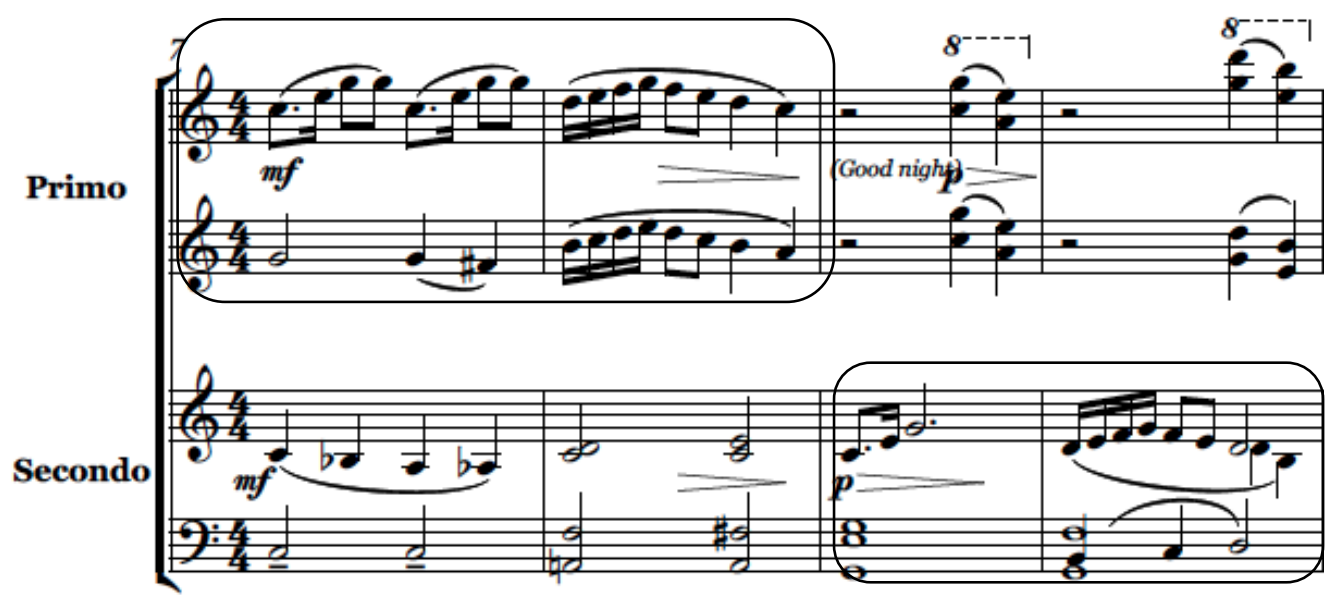

Copyright (c) 1962 Edward B. Marks Music Company

Copyright Renewed

Used by Permission 
Moreover, the composer also utilizes the "good-night" motif in measure nine of the primo as a counter-melody to the "Family Meeting" theme.

Example 8.5.3 Norman Dello Joio, Family Album, "V. Bed Time," measure 9, primo

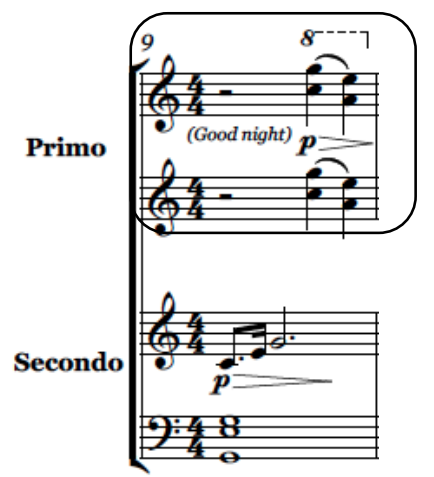

Copyright (c) 1962 Edward B. Marks Music Company

Copyright Renewed

Used by Permission

The bell-like motif returns again in measure 11 in the primo followed by a presentation in the secondo in the lower register of the piano. Additionally, Dello Joio features the final quote of the "Family Meeting" theme in E minor in measure 13 of the secondo, which brings the whole set to an end.

The meter here returns to a simple $4 / 4$ time signature. However, the harmony recalls the modern world in the third movement, "Story Time." The texture here is melody and accompaniment with a wide usage of pitches ranging over four octaves of the piano keyboard. This also recalls the hymn-like texture in the fourth movement, "Prayer Time."

A pedagogical concern of this movement is the note reading, as more modern chords are used in the secondo part and the spacing of the members in each chord is quite nontraditional. However, the most important challenge is in presenting the enjoyment of looking back at previous elements in this movement. This is categorized at the late elementary level. 
Family Album for piano, four hands is an effective and enjoyable set of duets for lateelementary and intermediate students. The descriptive title helps students imagine their own everyday lives. The structures and thematic unification found here are helpful for explaining in preparing students for awareness of structure in larger works. Studying Family Album according to the difficulty levels would be as follows: "Family Meeting," "Bed Time," "Story Time," "Prayer Time," and finally "Play Time." Students may want to play these pieces with their own family members, in order to experience an enjoyment similar to what Dello Joio had with his own children. 


\section{CHAPTER NINE}

\section{CONCLUSION}

There is a long history of composers writing works for their own children or family members, dating back as far as the Baroque period. Well-known piano pieces written for composers' own families include such works as:

J.S. Bach: Clavier-Büchlein vor Wilhelm Friedemann Bach (Notebook for Wilhelm Friedemann Bach) Clavier-Büchlein vor Anna Magdalena Bach (Notebookfor Anna Magdalena Bach)

Robert Schumann: Album for the Young Op. 68

Claude Debussy: Children's Corner (L. 113)

Gabriel Fauré: Dolly Suite Op. 56 for piano, four hands

Béla Bartók: Mikrokosmos

When speaking of twentieth-century music, one common misconception is that most of the repertoire is inaccessible, especially at the late-elementary and intermediate levels. However, the selected pieces in this research project represent several appealing and accessible works that provide an alternative to the traditional repertoire. The pieces studied here serve well as introductions to the twentieth-century compositional techniques of each composer and all represent twentieth-century composers who wrote music for and/or were inspired by their own children and family members.

Valse pour les enfants by Igor Stravinsky is a forgotten gem in the intermediate-level piano literature. The piece has a charming tune over a repetitive two-bar ostinato pattern in the left hand. It could be utilized for students' initial experience with waltz patterns and would serve well to teach students about dance movements such as the waltz and minuet in the style of the 
twentieth century. This could be utilized as an alternative repertoire choice to such pieces as Bach's Minuet from Clavier-Büchlein vor Anna Magdalena Bach (Notebook for Anna Magdalena Bach), Satie's Gymnopédie, Beethoven's Six Ecossaises WoO. 83, or Chopin's Waltz in A minor, Op. posth.

Quaderno Musicale di Annalibera (Musical Notebook for Annalibera) by Luigi Dallapiccola is the most challenging set among the repertoire selected for this document. However, it is an effective introduction to twelve-tone music. Though this set is the most farreaching in terms of accessibility, it is still playable and not too overwhelming for students who are having their first experience with twelve-tone music at the early-advanced level. Most of the movements are short, and all provide excellent opportunities for students to develop sound control (particularly in the quieter dynamics), note reading abilities, and understanding of musical structure. With their emphasis on color and tonal control, these pieces would make excellent alternatives to the Preludes by Debussy.

A Child's Exercise Book, Op. 69 by Dmitri Shostakovich (1906-75) features seven little pieces, all with descriptive titles. The titles are from emotions, activities, and objects to which young people can relate. The music in this set is very uplifting for children and adults alike. Moreover, the composer also included a birthday song in this set which can serve as an alternative to the traditional version. With their emphasis on developing independence of the hands and fingers and appealing rhythms, characters and melodies, this set serves well as an alternative or addition to such works as Burgmüller's "Arabesque" from 25 Études faciles et progressives Op.100; Gurlitt's Little Suite; Schumann's “Happy Farmer” from Album for the Young, Op. 68 and Clementi's famous Sonatina in C, Op. 36. 
Sonatine for Yvette by Xavier Montsalvatge is a wonderful alternative to Ravel's Sonatine or Debussy's Suite Bergamasque. This piece provides not only an introduction to a compact version of a twentieth-century neoclassical style, but also to elements of Spanish heritage such as Catalan folk music. The piece is very pianistic and not too lengthy. Moreover, the composer also features the familiar and charming Ah vous dirais-je, Maman tune in the third movement.

Family Album for piano four hands, by Norman Dello Joio is a set comprised of five piano pieces for piano duet which depict everyday life in the family. Each piece is written with a simple, captivating tune, with some use of modern harmony as well as a simple traditional harmony. The cyclic elements featured in the last movement, "Bed Time," are reminiscent of the day's activities in the previous movements. Moreover, the composer also features a hymn-like texture which relates to Dello Joio's family tradition of performing as a church organist. This set could be an alternative to Diabelli's piano duets or such pieces as Diabelli's Sonatina, Op. 163 and Diabelli’s Melodious Pieces, Op.169.

These works represent an important body of little-known works that can serve well as introductions to a variety of twentiety-century techniques. Studying such works helps to develop student's analytical skills, sight reading abilities, rhythmic skills and tonal control. These compositions can serve as another option for piano teachers who are looking to expand their own and their student's repertoire with various styles of piano music from the twentieth century. They can serve as an introduction to each composer's style. These works are valuable not only as study pieces but also as important musical compositions to be enjoyed and performed.

It is hoped that this study will encourage students and their teachers to discover in more depth the music of each of these composers and likewise that of the $20^{\text {th }}$ century. According to scholar Christopher Charles Hahn's quotation from Patricia Shand: 
"It is important that students understand how contemporary composers use techniques from previous periods, and also how they have developed new techniques. It is also important to make students aware of the range of styles used by contemporary composers. When developing a program of study, the teacher....must develop strategies for teaching those works so that the students understand the compositional techniques, master the technical challenges, and also experience the compositions aesthetically.",134

These works by Stravinsky, Dallapicolla, Shostakovich, Montsalvatge and Dello Joio all represent a variety of styles, levels and appeal which can serve this pedagogical need well expanding students' understanding and enjoyment of music.

\footnotetext{
${ }^{134}$ Hahn, Christopher Charles, "Canadian Pedagogical Piano Repertoire since 1970: A Survey of Contemporary Compositional Styles and Techniques" (DMA diss., The University of Okalahoma, 2005), 7.
} 


\section{BIBLIOGRAPHY}

Adams, Elizabeth. "The Treatment of the Piano Suite in the Twentieth Century as Exemplified by Schoenberg, Dello Joio, Donovan, and Apostel." D.M.A. diss, University of Cincinnati, 1974

Ardov, Michael. Memories of Shostakovich: Interviews with the Composer's Children and Friends. Great Britain: Mackays of Chatham Ltd., 2004.

Bumgardner, Thomas A., Norman Dello Joio. Boston: Massachusetts, Twayne Publihers, 1986.

Dillon, Frances. Family Album. "Piano Duet by Norman Dello Joio." Notes 21, no. 1/2 (Winter, 1963- Spring 1964): 248.

Craft, Robert. Stravinsky: Selected Correspondence Vol. I. New York: Alfred A. Knopf, 1982.

Evans, Roger, Xavier Montsalvatge: A Musical Life in Eventful Times. Hillsdale, NY: Pendregon Press, 2012.

Fearn, Raymond. The Music of Luigi Dallapiccola. Rochester: University of Rochester Press, 2003.

Fay, Laurel E. Shostakovich: A Life. New York: Oxford University Press, 2000

Forster, Susan H. “The Solo Piano Works of Igor Stravinsky.” Ph.D. diss., Indiana University, 1972.

Fritzwolter, Erick V. "The Solo Piano Works of Norman Dello Joio: A Performance Tape with Commentary. (text only).” Ph.D. diss., University of Maryland College Park, 1984.

Goldbeck, Frederik Twentieth Century Composers Volume IV: France, Italy, and Spain. London: Weidenfeld and Nicolson, 1974.

Griffiths, Graham. Stravinsky's Piano: Genesis of a Musical Language. Cambridge: Cambridge University Press, 2013

Hinson, Maurice. “The Solo Piano Works of Norman Dello Joio." American music teacher 19, no. 1 (January-February, 1970): $34-48$.

Hulme, Derek C. Dmitri Shostakovich Catalogue: The First Hundred Years and Beyond. Maryland: Scarecrow Press, Inc., 2010

Jackson, Stephen. Dmitri Shostakovich: An Essential Guide to His Life and Works. London: Pavillion Books Limited, 1998. 
Joseph, Charles M., “A Study of Igor Stravinsky's Piano Compositions.” Ph.D. diss., University of Cincinnati, 1974.

Joshua Martin, Timothy, "The Identification and Interpretation of Irony in Dmitri Shostakovich's Solo Piano Music." D.M.A. diss., The University of Alabama, 2006,

Machlis, Joseph, “14. Norman Dello Joio” In American Composers of Our Time” New York: Thomas Y. Crowell Company, 1963.

Magrath, Jane. "The Piano Music of Dmitri Shostakovich: Creative Genius Versus the Suppression of Artistic Expression." In The Pianist's Craft: Mastering the Works of Great Composer. Lanham, MD. : Scarecrow, 2012, 201-219.

Mann, Rachel Elice, “Tonal references in Luigi Dallapiccola's Quarderno Musicale Di Annalibera" M.M. thesis, Texas Tech University, 2002

Micheal Ardov. Memories of Shostakovich: Interviews with the Composer's Children and Friends, Great Britain: Mackays of Chatham Ltd., 2004.

Petito, Sue B. "The Piano Works of Luigi Dallapiccola (1904-1975) : An Analysis for Performance.” Ph.D. diss., New York University, 1989.

Sollertinsky, Dmitri and Ludmilla. Pages from the life of Dmitri Shostakovich. Harcourt Brace Jovanovich, 1980

Steffan, Andrea J. "Selected Piano Works by Norman Dello Joio." Ph.D. diss., University of Cincinnati, 2001.

Stevenson, Ronald. "The Piano Music" In Shostakovich: The Man and his Music. Boston: M. Boyars, 1982, 81-104.

Thal, Marlene. "The Piano Music of Igor Stravinsky." Ph.D. diss., University of Washington, Seattle, 1978.

Violett, Martha L. "The Solo Piano Music of Xavier Montsalvatge." Ph.D. diss., University of Iowa, 1990.

Wilson, Elizabeth. Shostakovich: A Life Remembered. Princeton University Press, 1994.

Yang, Shu-Ting. "Salute to Bach: Modern Treatments of Bach- Inspired Elements in Luigi Daallapiccola's Quarderno Musicale di Annalibera and Heitor Villa- Lobos' Bachianas Brasileiras No.4." DMA diss., The University of Cincinnati, 2007. 